Peta Jalan

Pengembangan

PLTS Atap:

Menuju Bali

Mandiri Energi
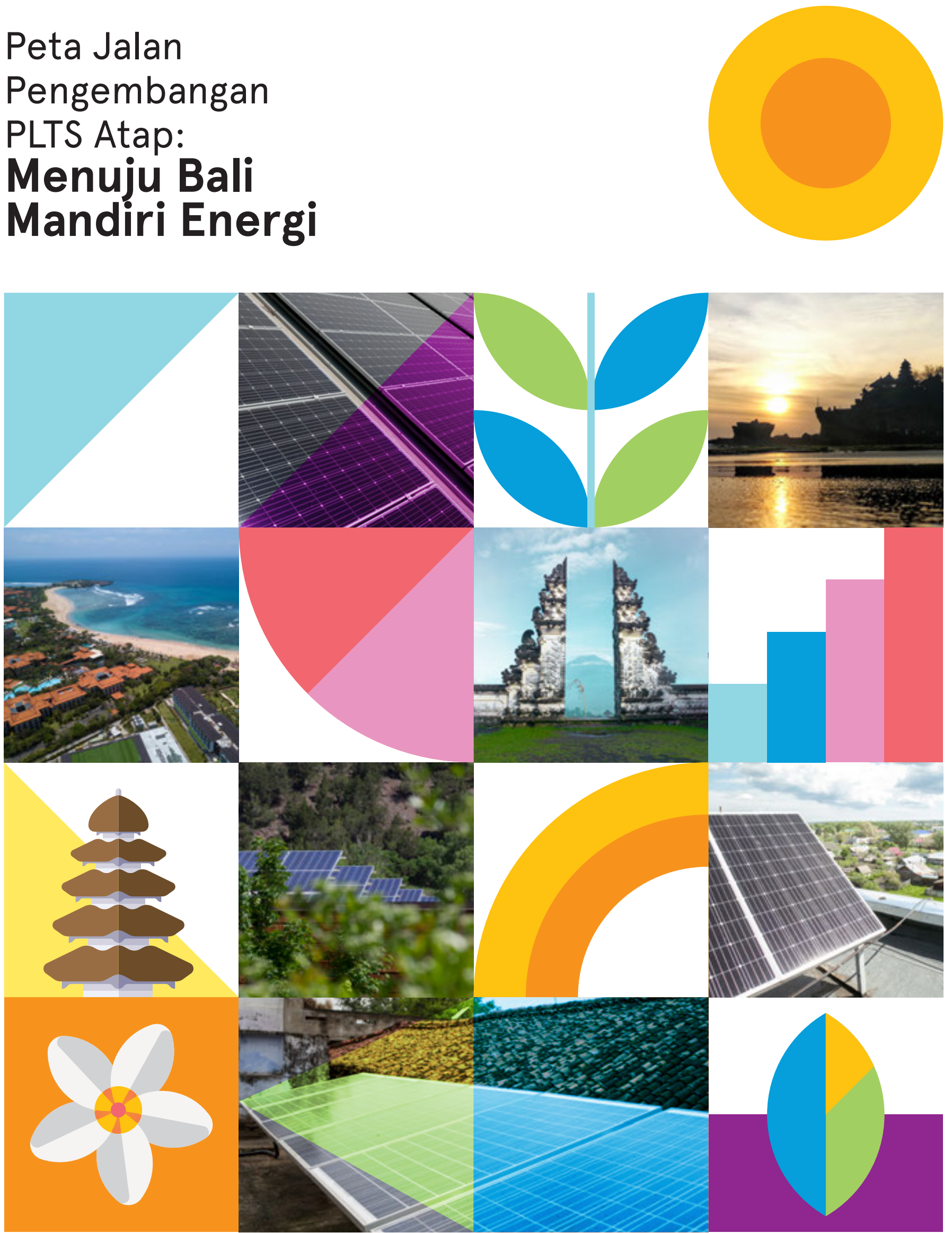



\section{Peta Jalan Pengembangan PLTS Atap: Menuju Bali Mandiri Energi}


Tim Peneliti

- Center for Community Based Renewable Energy (CORE) Universitas Udayana

- Prof. Ida Ayu Dwi Giriantari, PhD

- I Nyoman Satya Kumara, PhD

- Wayan Gede Ariastina, PhD

- Ir. Wayan Sukerayasa, MT

- Ir. Nyoman Setiawan, MT

- Ir. Cok Gede Indra Partha, MT

- Ir. I Gede Dyana Arjana, MT

- Greenpeace Indonesia

- Tata Mustasya

- Adila Isfandiari

- Satrio Swandiko Prillianto

\section{Penulis}

- I. N. S. Kumara

- I. A. D. Giriantari

- W. G. Ariastina

- W. Sukerayasa

- N. Setiawan

- C. G. I. Partha

- I. G. D. Arjana

\section{Rekomendasi untuk sitasi}

I.N.S. Kumara, I.A.D. Giriantari, W.G. Ariastina, W. Sukerayasa, N. Setiawan, C.G.I Partha, I.G.D. Arjana, Peta Jalan Pengembangan PLTS Atap: Menuju Bali Mandiri Energi, Center for Community Based Renewable Energy (CORE) Universitas Udayana, Greenpeace Indonesia, Bali, 2019

\section{Disklaimer}

Isi laporan ini bukan merupakan pandangan dari CORE Universitas Udayana atau Greenpeace Indonesia tapi adalah hasil kajian yang dilakukan oleh Tim Peneliti. Isi yang disampaikan dalam laporan ini bersifat akademis informatif dan tidak dibuat untuk kepentingan komersial.
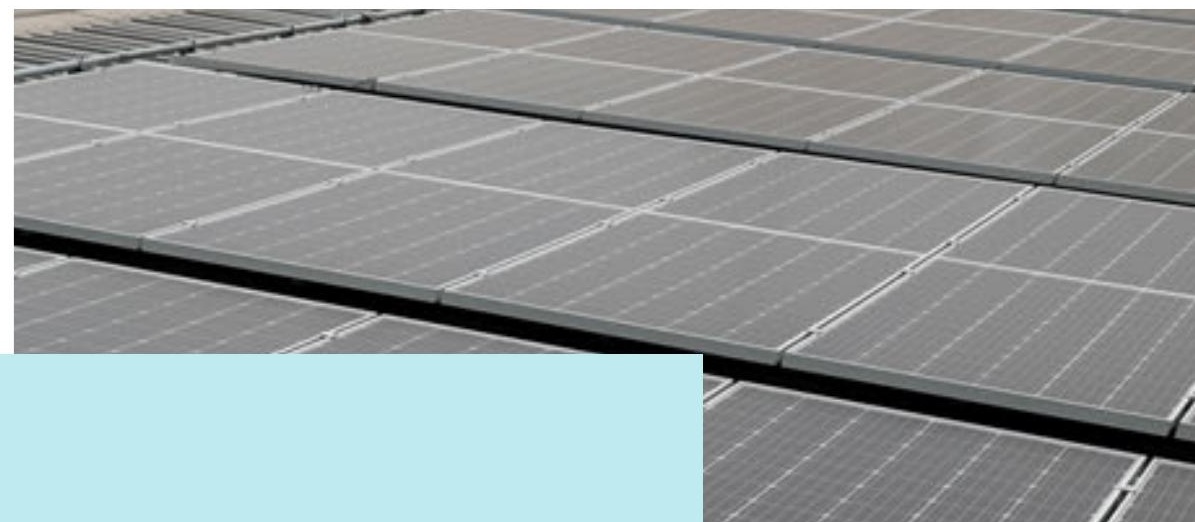


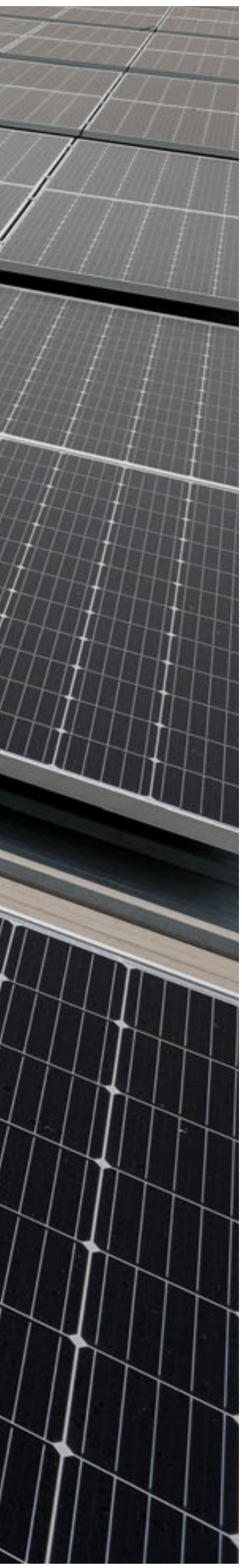

\section{Kata \\ Pengantar}

Puji syukur kami panjatkan kepada Tuhan Yang Maha Esa karena atas berkat dan rahmat-Nya, Buku Peta Jalan Pengembangan PLTS Atap: Menuju Bali Mandiri Energi dapat diselesaikan dengan baik.

Buku ini merupakan hasil kajian Tim Peneliti dari Center for Community Based Renewable Energy (CORE) Universitas Udayana dan Greenpeace Indonesia sebagai luaran dari Kerjasama antara Universitas Udayana dan Greenpeace Indonesia.

Dalam buku ini dipaparkan bagaimana potensi matahari di Bali dan potensi atap bangunan untuk digunakan dalam penerapan PLTS Atap. Fokus kajian luas atap bangunan ini dibatasi pada bangunan milik Pemerintah Provinsi Bali, Pemerintah Kabupaten/Kota SARBAGITA, PLN UID Bali, Perguruan Tinggi di Bali, sektor pariwisata khususnya Indonesia Tourist Development Corporation (ITDC) Nusa Dua, dan Desa Adat. Hasil kajian ini diharapkan dapat membantu pemangku kepentingan energi terbarukan di Bali dalam memahami bagaimana potensi tiap pemangku kepentingan dalam mendukung pencapaian target kapasitas PLTS 108 MW untuk Bali pada tahun 2025.

Terima kasih kami ucapkan kepada semua pihak yang telah mendukung kegiatan penyusunan Peta Jalan ini. Terima kasih kepada Greenpeace Indonesia, PT PLN (Persero) UID Bali, semua Badan Usaha yang bergerak di bidang PLTS di Bali, serta komponen masyarakat yang tidak dapat disebutkan satu demi satu.

Semoga buku ini dapat memberikan manfaat bagi masyarakat Bali dalam upaya membangun Bali bersih dan berkelanjutan dari sisi energi. Saran dan kritik kami terima dengan senang hati untuk perbaikan ke depan.

Bukit Jimbaran, 31 Agustus 2019

Ketua Center for Community Based Renewable Energy

Prof. Ida Ayu Dwi Giriantari, PhD 


\section{Daftar Isi}

Kata Pengantar 3

Daftar Gambar $\longrightarrow 5$

Daftar Tabel 6

Daftar Istilah 6

Ringkasan Eksekutif — 7

Pendahuluan 10

Metodologi 14

Kondisi Geografis Bali 16

Sistem Ketenagalistrikan Bali 19

Pembangkit Listrik Tenaga Surya 22

Tantangan Pengembangan PLTS di Bali 28

PLTS Rooftop Sebagai Solusi 30

PLTS Atap Ekisting Di Provinsi Bali 31

Regulasi PLTS Atap 36

Kontraktor PLTS Di Bali 37

Investasi PLTS Atap 38

Potensi PLTS Atap di Bali $\mathbf{4 0}$

PT PLN UID Bali 41

Pemerintah Provinsi Bali dan SARBAGITA 41

Perguruan Tinggi di Bali 44

ITDC Nusa Dua 45

Potensi Desa Adat Bali 46

Rekomendasi Pengembangan PLTS Atap Bali 47

Kapasitas PLTS Atap 47

Kebijakan dan Regulasi — 49

Edukasi dan Sosialisasi 51

Model Pembiayaan 51

Sumber Daya Manusia $\quad 52$

Layanan Purna Jual 53

Koneksi Ke Jaringan PLN 53

Daftar Pustaka $\mathbf{5 4}$ 


\section{Daftar Gambar}

Gambar 1. Bauran energi Indonesia 2025 dan $2050 \_10$

Gambar 2. Pembangkitan listrik dengan EBT tahun 2025 _ 11

Gambar 3. Potensi PLTS Indonesia berdasarkan RUEN — 12

Gambar 4. Luas wilayah Kabupaten/Kota di Bali dan penduduknya _ 16

Gambar 5. Akomodasi wisata di Bali 17

Gambar 6. Jumlah kunjungan wisatawan ke Bali — 17

Gambar 7. Penerimaan Daerah Kabupaten/Kota di Bali — 18

Gambar 8. Sistem kelistrikan Bali 20

Gambar 9. Bauran pembangkitan tenaga listrik Bali 2019 dan 2025

Gambar 10. Pelanggan PLN di Bali Tahun 2017 _ 21

Gambar 11. Skematik Pembangkit Listrik Tenaga Surya _ 22

Gambar 12. Indeks radiasi matahari di pusat Kabupaten/ Kota di Bali _ 23

Gambar 13. Skematik sistem LTHSE dan instalasinya di rumah terpencil — 24

Gambar 14. Skematik PLTS off-grid — 25

Gambar 15. PLTS off-grid untuk komunitas di daerah terpencil — 25

Gambar 16. PLTS on-grid ground mount di Desa Kayubihi kapasitas 1 MWp 26

Gambar 17. Aplikasi tipikal PLTS Atap 27

Gambar 18. Potensi atap bangunan dari kompleks Pusat Pemerintahan Kabupaten Badung _ 30

Gambar 19. Potensi atap bangunan Hotel Ayodya Resort Bali di kawasan ITDC Nusa Dua _ _ 31

Gambar 20. PLTS Atap 158 kWp di Kantor Gubernur Bali 31

Gambar 21. PLTS Atap 26 kWp di Universitas Udayana _ 32

Gambar 22. PLTS Atap untuk instalasi pengolahan limbah masyarakat 32

Gambar 23. PLTS Atap di Kantor PLN UID Bali 33

Gambar 24. PLTS Atap 24 kWp di Indonesia Power Pesanggaran _ 33

Gambar 25. PLTS Atap di Hotel Mercure Bali 34

Gambar 26. PLTS Atap di kawasan resort The Longhouse Bali 35

Gambar 27. Sebaran PLTS Atap di Bali 35

Gambar 28. Skematik PLTS Atap sesuai Permen ESDM 49/2018_ 36

Gambar 29. Mekanisme pengajuan penyambungan PLTS Atap ke jaringan PLN 36

Gambar 30. Kisaran harga PLTS Atap di Bali tahun 2019 _ 38

Gambar 31. Simulasi produksi energi PLTS Atap $10 \mathrm{kWp}=39$

Gambar 32. Simulasi produksi energi PLTS Atap $15 \mathrm{kWp} 39$

Gambar 33. Simulasi produksi energi PLTS Atap $20 \mathrm{kWp} \longrightarrow 39$

Gambar 34. Wilayah Bali Selatan atau SARBAGITA sebagai fokus kajian 40

Gambar 35. Kantor PLN Bali tersebar di seluruh Bali 41

Gambar 36. Foto udara Kantor Gubernur Bali _ 42

Gambar 37. Komplek Gedung Sewaka Dharma milik Pemerintah Kota Denpasar _ 42

Gambar 38. Pusat Pemerintahan Kabupaten Badung — 43

Gambar 39. Pusat pemerintahan Kabupaten Gianyar _ 43

Gambar 40. Pusat pemerintahan Kabupaten Tabanan _ 44

Gambar 41. Kampus Universitas Udayana di Denpasar _ 44

Gambar 42. Foto udara kawasan wisata ITDC Nusa Dua $\quad 45$

Gambar 43. Bangunan balai banjar adat Tegal Denpasar $\quad 46$

Gambar 44. Rencana Perkembangan PLTS di Bali 2020 - $2025 \_48$

Gambar 45. Matrik kegiatan pemangku kepentingan menuju tahun 2025 dan $2050 \_48$

Gambar 46. Negara dengan kapasitas PLTS terbesar di dunia 50 


\section{Daftar Tabel}

Tabel 1. Badan Usaha yang bergerak dalam pemasangan PLTS Atap di Bali -37

Tabel 2. Harga PLTS Atap berbagai kapasitas _ 38

Tabel 3. Jumlah balai banjar di wilayah SARBAGITA 46

Tabel 4. Potensi luas atap dan PLTS Atap 46

\section{Daftar Istilah}

\begin{tabular}{|c|c|c|c|}
\hline AESI & Asosiasi Energi Surya Indonesia & LIT & Lembaga Inspeksi Teknik \\
\hline \multirow[t]{2}{*}{ APAMSI } & Asosiasi Pabrikan Modul Surya & LPJU & Lampu Penerangan Jalan Umum \\
\hline & Indonesia & LPD & Lembaga Perkreditan Desa \\
\hline \multirow[t]{2}{*}{ APBD } & Anggaran Pendapatan dan Belanja & LTSHE & Lampu Tenaga Surya Hemat Energi \\
\hline & Daerah & METI & Masyarakat Energi Terbarukan \\
\hline B2B & Business to Business & & Indonesia \\
\hline BPPT & Badan Pengkajian Penerapan Teknologi & MW & Mega Watt \\
\hline BPS & Badan Pusat Statistik & MWp & Mega Watt peak \\
\hline BTS & Base Transceiver Station & P3TKEBTKE & Pusat Penelitian dan Pengembangan \\
\hline BUMN & Badan Usaha Milik Negara & & Teknologi Ketenagalistrikan, Energi \\
\hline BUMDES & Badan Usaha Milik Desa & & Baru Terbarukan dan Konservasi Energi \\
\hline \multirow[t]{2}{*}{ CORE } & Center for Community Based & PAD & Pendapatan Asli Daerah \\
\hline & Renewable Energy & Permen & Peraturan Menteri \\
\hline CSR & Corporate Social Responsibility & PLN & Perusahaan Listrik Negara \\
\hline EBT & Energi Baru Terbarukan & PLTS & Pembangkit Listrik Tenaga Surya \\
\hline \multirow[t]{2}{*}{ EBTKE } & Energi Baru Terbarukan dan Konversi & POLTEK & Politeknik \\
\hline & Energi & PPSA & Perkumpulan Pengguna Surya Atap \\
\hline EPC & Engineering Procurement Company & PTN & Perguruan Tinggi Negeri \\
\hline ESCO & Energy Services Companies & PTS & Perguruan Tinggi Swasta \\
\hline ESDM & Energi dan Sumber Daya Mineral & PV & Photovoltaic \\
\hline GW & Giga Watt & RUEN & Rencana Umum Energi Nasional \\
\hline IMB & Izin Mendirikan Bangunan & SARBAGITA & Denpasar Badung Gianyar Tabanan \\
\hline IPP & Independent Power Producer & SHS & Solar Home System \\
\hline \multirow[t]{2}{*}{ ITDC } & Indonesia Tourist Development & SDG & Sustainable Development Goal \\
\hline & Corporation & SLO & Sertifikat Laik Operasi \\
\hline \multirow[t]{2}{*}{ KKIFN } & Konsorsium Kemandirian Industri & TKDN & Total Kandungan Dalam Negeri \\
\hline & Fotovoltaik Nasional & UMKM & Usaha Mikro Kecil Menengah \\
\hline kWh & Kilo Watt hour & UID & Unit Induk Distribusi \\
\hline LED & Light Emitting Diode & & \\
\hline
\end{tabular}




\section{Ringkasan Eksekutif}

Rencana Umum Energi Nasional (RUEN), yang merupakan pedoman pengembangan energi nasional, telah menetapkan Pembangkit Listrik Tenaga Surya (PLTS) sebagai salah satu sumber energi terbarukan yang sudah dan akan dikembangkan. Dalam RUEN juga disebutkan bahwa Indonesia menargetkan kapasitas PLTS nasional sebesar 6,5 GW pada tahun 2025 dan meningkat menjadi $45 \mathrm{GW}$ pada tahun 2050. Target nasional kapasitas PLTS tersebut didistribusikan ke 34 wilayah provinsi di Indonesia di mana Provinsi Bali ditetapkan untuk mencapai kapasitas PLTS sebesar 108 MW pada tahun 2025.

Sampai saat ini, peran pembangkit listrik terbarukan di Provinsi Bali masih sangat kecil. Padahal sebagai wilayah dengan iklim tropis, Provinsi Bali memiliki potensi energi terbarukan yang sangat besar, terutama energi surya. Dibandingkan energi terbarukan lainnya, energi surya di Provinsi Bali memiliki potensi yang paling tinggi, yaitu sekitar $98 \%$ dari total potensi energi terbarukan yang terdapat di Bali. Simulasi dengan RETScreen dan Helioscope menunjukkan potensi energi matahari di pusat kabupaten/Kota di Bali berkisar antara 4,01-6,13 kWh/ $\mathrm{m}^{2} /$ hari dengan rata-rata 4,89 $\mathrm{kWh} / \mathrm{m}^{2} /$ hari. Karena Bali merupakan pulau yang relatif kecil, perbedaan potensi energi matahari di 8 kabupaten/Kota tidak terlalu besar. Selain itu, berdasarkan beberapa penelitian, total potensi energi surya di Provinsi Bali dapat jauh melebihi jumlah kebutuhan energi penduduknya dalam sepuluh tahun mendatang seperti yang tercantum dalam Rencana Usaha Penyediaan Tenaga Listrik (RUPTL) 2019-2028.

Dari sisi konfigurasi pembangkit, aplikasi PLTS di Provinsi Bali sudah cukup beragam, seperti sistem skala kecil untuk penerangan rumah tangga di desa dalam bentuk solar home system, sistem off-grid yang berkapasitas cukup besar untuk menerangi kelompok masyarakat yang berada di luar jangkauan jaringan PLN, hingga sistem skala besar yang terkoneksi ke jaringan PLN. Namun, kapasitas total terpasang PLTS di Bali masih kecil, berkisar antara 3 4 MWp. Dibandingkan dengan target RUEN untuk Bali sebesar 108 MWp, maka kapasitas PLTS yang harus dibangun dalam enam tahun ke depan hingga 2025 masih sangat besar.

Berbagai faktor yang memperlambat perkembangan PLTS di Bali telah diidentifikasi melalui forum diskusi dan wawancara dengan pemangku kepentingan energi terbarukan di Bali dan juga tinjauan pada perkembangan kapasitas terpasang PLTS nasional. Pengembangan PLTS skala besar terkendala oleh kebutuhan lahan yang luas untuk pemasangan modul surya. Bali yang merupakan pulau yang relatif kecil dan dengan perkembangan pariwisata yang terjadi di seluruh wilayahnya memiliki ketersediaan lahan yang terus menurun dengan harga yang tinggi. Di samping itu, pembangunan PLTS skala utilitas dengan kapasitas di atas $1 \mathrm{MW}$ memerlukan kajian yang rinci mengenai lokasi pembangkit dan dampaknya terhadap sistem ketenagalistrikan.

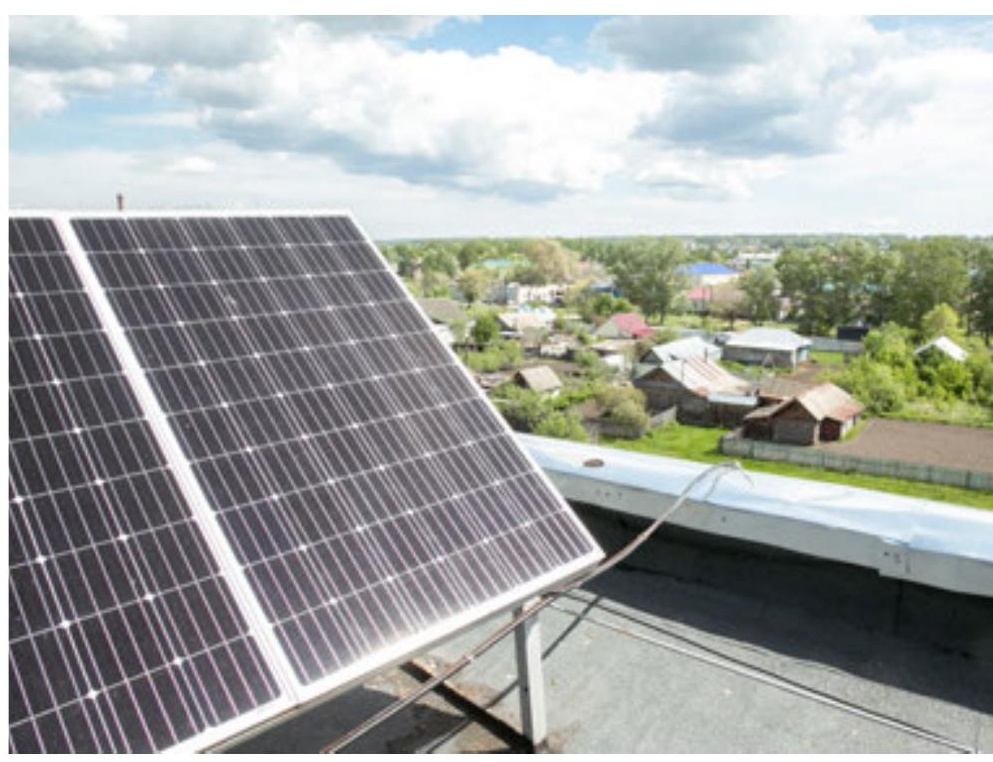




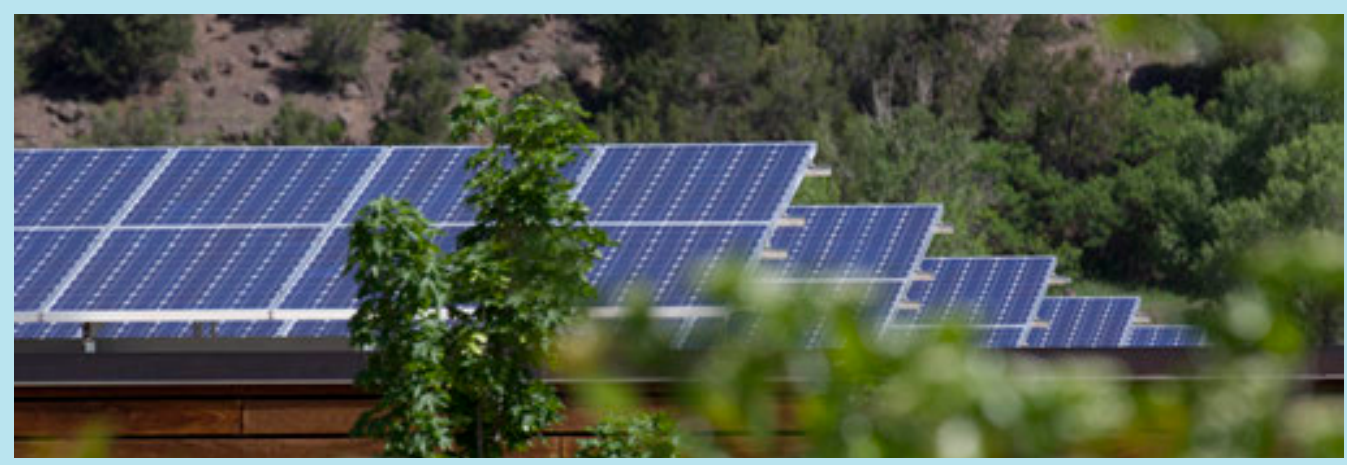

Menghadapi berbagai tantangan tersebut, salah satu solusi pengembangan PLTS yang dapat dilakukan di Bali dalam adalah PLTS Atap. Kelebihan PLTS Atap dibanding dengan ground mount system, antara lain: 1) tidak memerlukan lahan sehingga menghindari terjadinya alih fungsi lahan, 2) bersifat tersebar mengikuti sebaran demografi dan berkapasitas relatif kecil karena dibatasi oleh luas atap sehingga masih dalam batasan kapasitas jaringan distribusi PLN. Saat ini, total kapasitas terpasang PLTS di Bali masih didominasi oleh ground mount system yang terpasang di Bangli dan Karangasem. Kedua PLTS skala besar ini merupakan $57 \%$ dari total terpasang PLTS di Bali sehingga PLTS Atap perlu diberikan perhatian yang serius sebagai solusi energi bersih, hijau, tersebar/ terdesentralisasi, dan berkelanjutan.

Terhambatnya perkembangan PLTS Atap di Bali disebabkan berbagai faktor, di antaranya pengetahuan masyarakat tentang PLTS yang masih terbatas, investasi awal yang besar, kendala terkait pengoperasian dan pemeliharaan, layanan purna jual, dan regulasi. Pemahaman sebagian besar masyarakat tentang PLTS belum memadai sehingga membutuhkan waktu untuk memahami teknologi ini sebelum memutuskan untuk membangun PLTS. Selain itu, mahalnya harga sistem PLTS juga merupakan kendala bagi masyarakat. Sebagai contoh, saat ini harga pemasangan PLTS Atap terkoneksi PLN siap operasi berkisar antara 15 - 20 juta rupiah per kilowatt untuk kapasitas antara 10 - $20 \mathrm{kWp}$ tergantung lokasi dan kondisi pemasangan PLTS.

Regulasi juga belum kondusif, di mana terdapat keluhan dari masyarakat yang secara finansial sudah mampu untuk memasang PLTS Atap. Salah satunya, waktu tunggu pemasangan kWh meter eksporimpor yang cukup lama, yaitu satu hingga enam bulan. Selain itu, terdapat kesulitan pemeliharaan sistem PLTS Atap yang sudah terpasang karena belum berkembangnya jasa teknis pemeliharaan PLTS Atap. Sebagian besar dari PLTS Atap yang telah dibangun di Bali dipasang oleh kontraktor yang belum atau tidak memiliki cabang di Bali sehingga menyebabkan kendala dalam layanan purna jual.

Dalam kajian ini, terdapat lima kelompok pemangku kepentingan PLTS di Bali, yaitu: 1) Pemerintah yang terdiri dari Pemerintah Provinsi dan Pemerintah Kabupaten/Kota Denpasar, Badung, Gianyar, dan Tabanan yang dikenal dengan istilah SARBAGITA, 2) institusi pendidikan yang terdiri dari Perguruan Tinggi, 3) penyedia tenaga listrik yaitu PT PLN (Persero) UID Bali, 4) industri pariwisata yaitu Indonesia Tourist Development Corporation (ITDC) Bali yang mengelola kawasan wisata Nusa Dua, 5) dan masyarakat Desa Adat Bali di wilayah SARBAGITA. Wilayah SARBAGITA diambil sebagai fokus kajian karena berbagai indikator strategis yang dimiliki oleh gabungan empat pemerintah kabupaten/kota ini yang secara geografis berada di wilayah Bali bagian selatan.

Potensi pemangku kepentingan dalam pengembangan PLTS Atap dapat dilihat dari luasan atap bangunan yang dimiliki. Luasan atap yang dipadukan dengan teknologi PLTS Atap yang ada saat ini digunakan sebagai dasar untuk mengkaji potensi PLTS Atap dari pemangku kepentingan di wilayah SARBAGITA. Potensi PLTS Atap 
dihitung dengan skenario pemanfaatan luas atap sebanyak 25\% hingga 60\% dari luas keseluruhan atap bangunan. Untuk membangun PLTS Atap berkapasitas 10 kWp membutuhkan sekitar 60 meter persegi atap. Potensi total PLTS Atap dari pemangku kepentingan di Bali yang terdiri dari Pemerintah Provinsi, Pemerintah SARBAGITA, PLN Bali, Perguruan Tinggi di Bali, ITDC Nusa Dua, dan Desa Adat Bali berkisar antara $49.504-129.778 \mathrm{kWp}$ dengan pemanfaatan luas atap bangunan berkisar dari 25\% hingga 60\%. Angka ini menunjukkan bahwa Bali memiliki potensi PLTS Atap yang besar untuk mencapai target PLTS 108 MW pada tahun 2025.

Merujuk pada perhitungan dalam kajian ini, target PLTS sebesar $108 \mathrm{MW}$ di dalam RUEN ini dapat dengan mudah dicapai oleh Provinsi Bali pada tahun 2025, hanya dengan memanfaatkan lima kelompok pemangku kepentingan di wilayah Metropolitan SARBAGITA saja. Di luar target di dalam RUEN, Provinsi Bali seharusnya memiliki target kapasitas PLTS yang jauh lebih ambisius dengan memanfaatkan total potensi energi surya untuk mencapai kemandirian energi. Penggunaan energi surya di Bali juga mendukung pelaksaanaan komitmen Gubernur Provinsi Bali untuk melakukan transisi energi dari energi batu bara menuju energi bersih.

Pencapaian target tersebut memerlukan sinergi pemangku kepentingan dan masyarakat. Untuk itu, perlu dilakukan kampanye dengan metode yang lebih inovatif dan luas. PLN Bali dan sektor pariwisata juga perlu didorong untuk lebih progresif dalam membangun PLTS Atap.

Dari aspek pembiayaan diperlukan upaya inovatif melalui kolaborasi berbagai pihak, di antaranya pemerintah pusat, sektor perbankan, BUMN, pemerintah kabupaten/kota melalui APBD, perguruan tinggi melalui dana riset atau kerjasama, dan desa adat melalui Dana Desa/BUMDes/LPD/Koperasi. Dari aspek penyediaan tenaga teknis untuk mendukung pemeliharaan dan perawatan PLTS, diperlukan program pendidikan atau pelatihan oleh PTN/PTS/POLTEK atau lembaga yang bergerak di bidang ketenagakerjaan. Untuk menjaga keberlanjutan pengoperasian PLTS Atap diperlukan jasa layanan teknis perawatan atau pemeliharaan oleh lembaga berskala UMKM. Ke depan, secara keseluruhan, diperlukan stimulasi untuk menciptakan "ekosistem" yang mendukung pengembangan PLTS Atap. 


\section{1.}

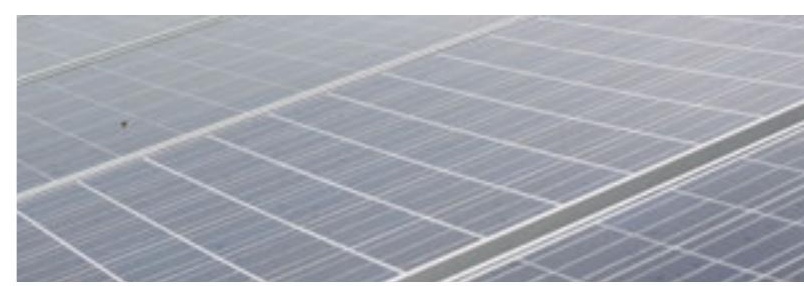

\section{Pendahuluan}

Pemerintah Pusat telah menetapkan Rencana Umum Energi Nasional yang merupakan acuan bagi pengembangan energi di Indonesia. RUEN ditetapkan melalui Peraturan Presiden No 22 Tahun 2017. Dalam RUEN Indonesia merencanakan untuk meningkatkan peran Energi Terbarukan dalam bauran energi nasional menjadi $23 \%$ pada tahun 2025 dan meningkat menjadi $31 \%$ pada tahun 2050. Rencana bauran energi nasional tahun 2025 dan 2050 diperlihatkan pada Gambar 1.

\section{Bauran Energi Indonesia 2025 (MTOE)}

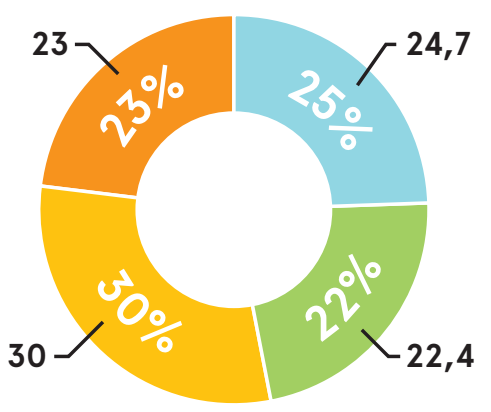

Bauran Energi Indonesia 2050 (MTOE)

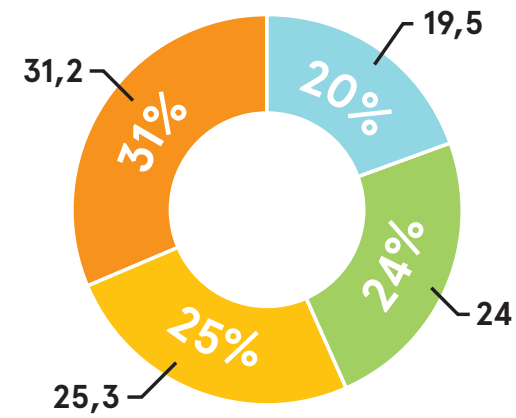

Gas Bumi

Batu Bara

Gambar 1. Bauran energi Indonesia 2025 dan 2050 
Pada tahun 2025 dalam RUEN diperkirakan bahwa kapasitas kelistrikan nasional adalah $135 \mathrm{GW}$ dan $45 \mathrm{GW}$ harus berasal dari pembangkitan dengan Energi Baru Terbarukan. Komposisi EBT terdiri dari panas bumi, tenaga air, mikrohidro, bioenergi, tenaga matahari, tenaga angin, dan EBT lainnya. Komposisi EBT berdasarkan teknologi diperlihatkan pada Gambar 2.

\section{Rencana Komposisi Pembangkit EBT 2025 - 45 GW}

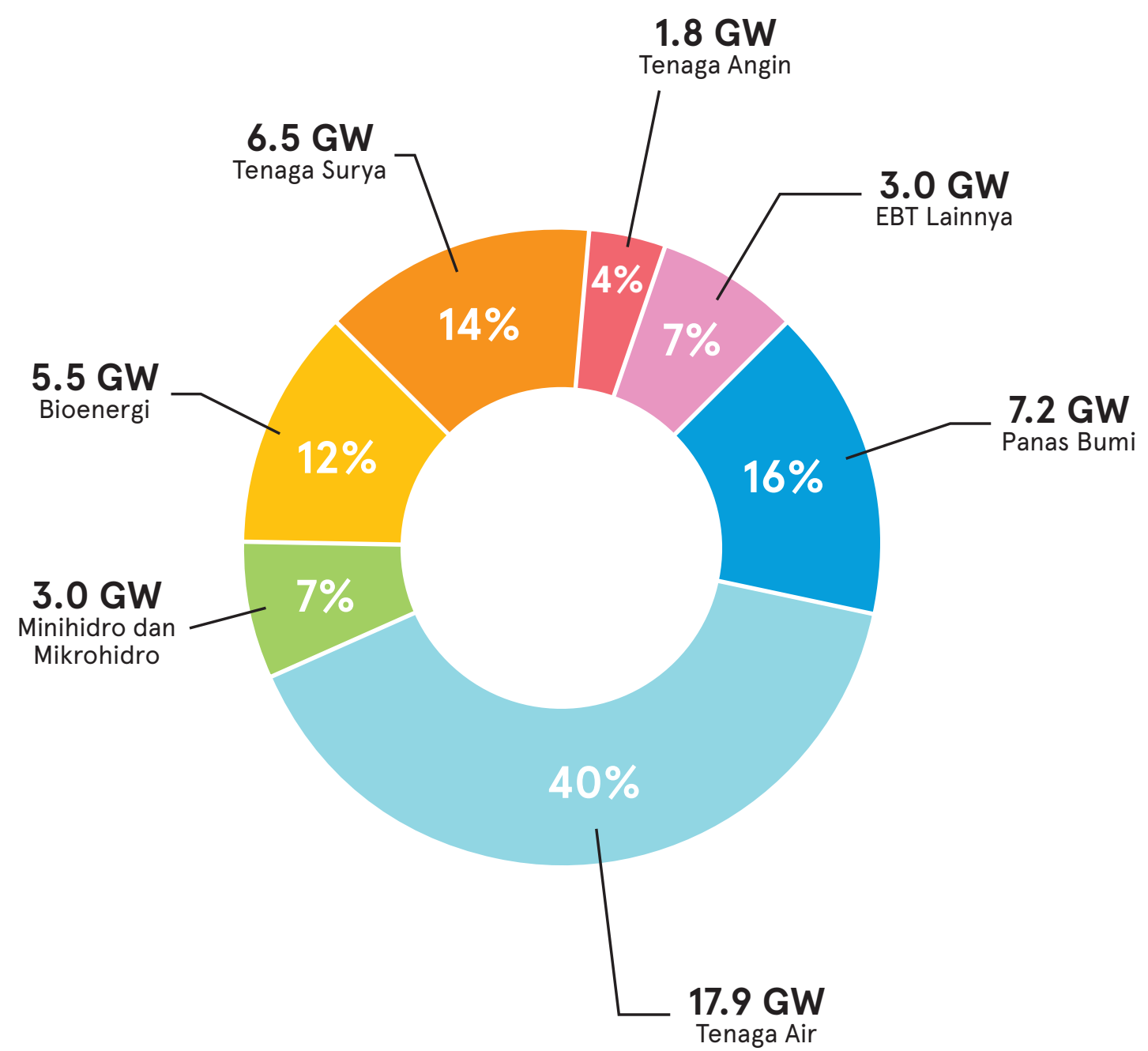

Gambar 2. Pembangkitan listrik dengan EBT tahun 2025 
Tenaga surya sebagai salah satu bentuk energi terbarukan telah dan akan dikembangkan sebagai salah satu solusi energi bersih dan berkelanjutan bagi Indonesia. Potensi tenaga surya di Indonesia dalam RUEN diperkirakan mencapai 208 GW sehingga akan merupakan salah satu sumber energi penting dalam portofolio energi di masa depan. Potensi kapasitas PLTS di setiap Provinsi berdasarkan RUEN diperlihatkan pada Gambar 3.

\section{Target Kapasitas PLTS 2025 dan Potensi}

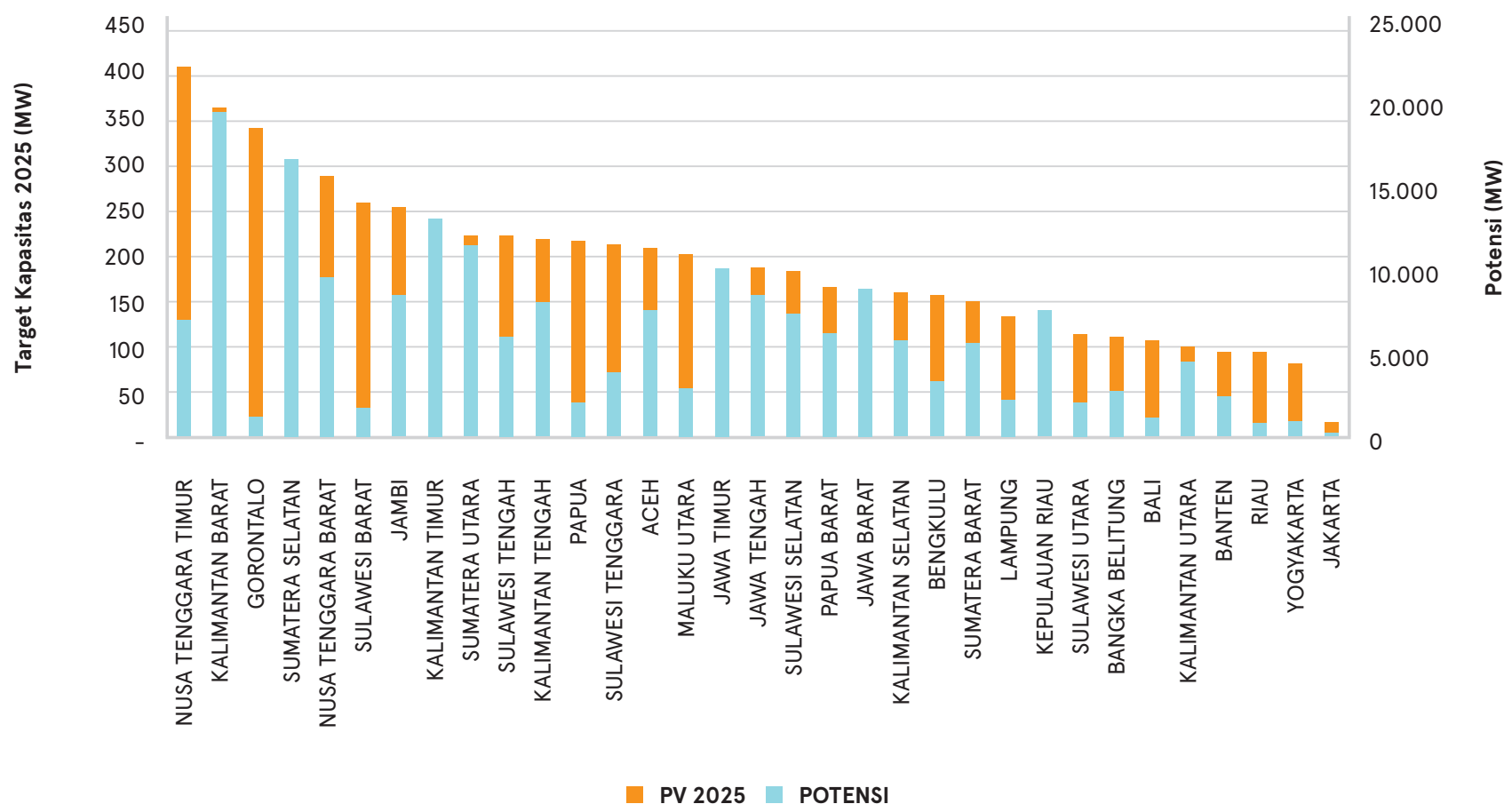

Gambar 3. Potensi PLTS Indonesia berdasarkan RUEN

RUEN menargetkan bahwa Indonesia akan membangun PLTS dengan kapasitas 6.500 MW tahun 2025 dan meningkat menjadi 45.000 MW pada tahun 2050. Berdasarkan RUEN, seluruh Indonesia mendapat porsi untuk membangun PLTS untuk secara bersama-sama mewujudkan target tersebut.
Pemanfaatan PLTS secara nasional sampai tahun 2017 menurut Kementerian ESDM baru mencapai 80 MW. $\mathrm{Hal}$ ini menunjukkan bahwa diperlukan kerja keras dan langkah-langkah percepatan untuk mencapai target yang telah ditetapkan dalam RUEN. 


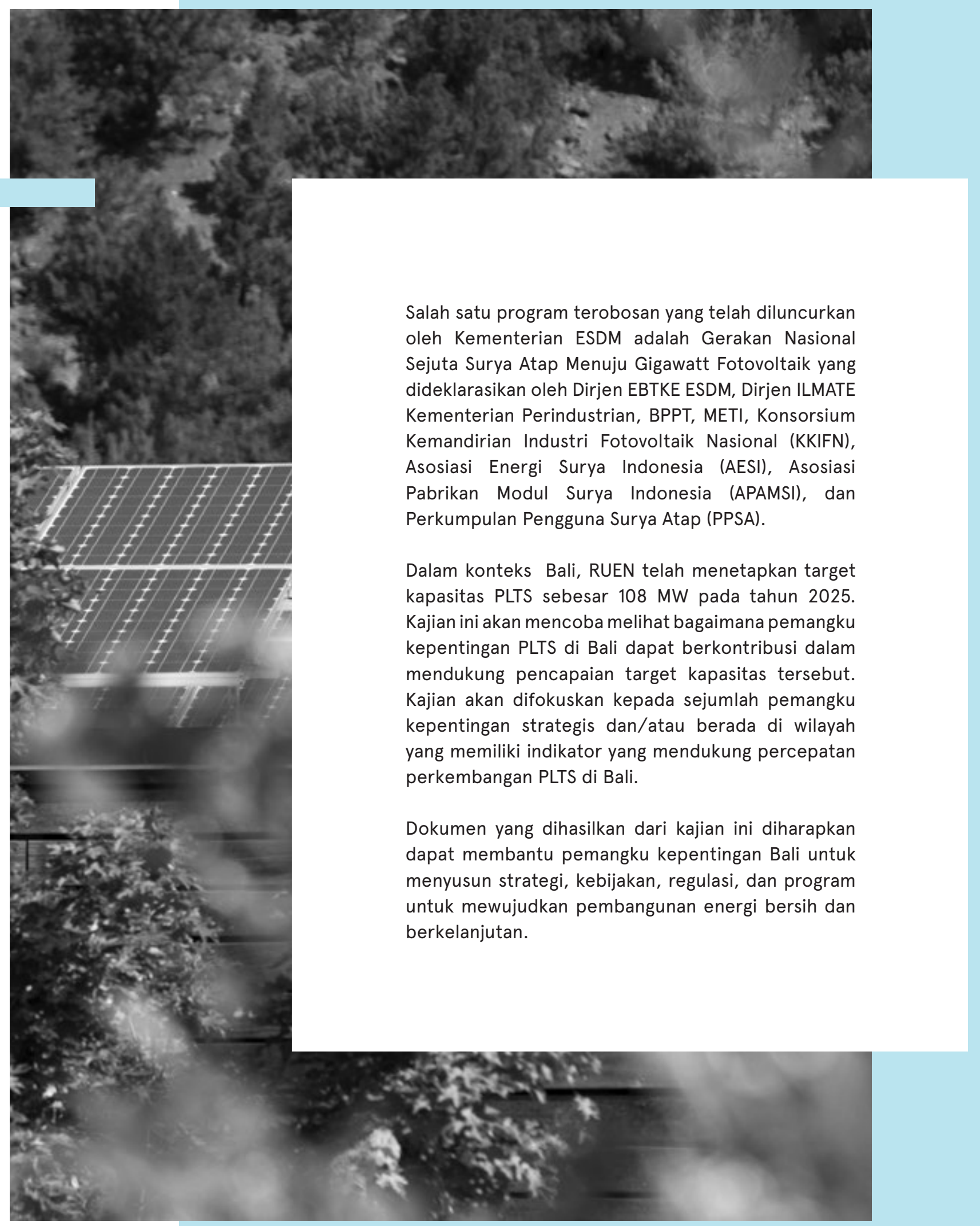




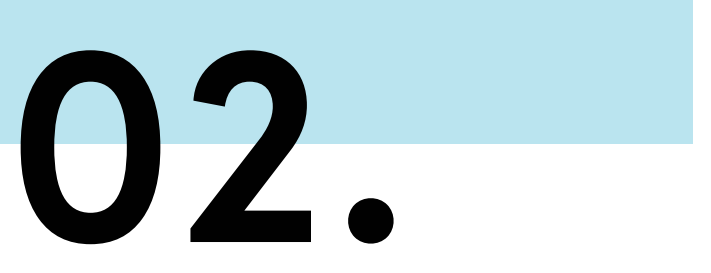

\section{Metodologi}

Kajian tentang potensi PLTS di Bali akan difokuskan pada wilayah Bali Selatan atau yang juga dikenal dengan wilayah SARBAGITA. Beberapa indikator strategis dipilihnya wilayah SARBAGITA sebagai fokus kajian adalah sebagai berikut berdasarkan data tahun 2017. Secara demografi, sebanyak 59\% dari 4,3 juta penduduk Bali terkonsentrasi di wilayah SARBAGITA dan sisanya tersebar di lima wilayah kabupaten lain. Secara ekonomi, total jumlah Penerimaan Daerah seluruh Kabupaten/Kota di Bali adalah 17.7 triliun dan $60 \%$ nya berada di wilayah SARBAGITA. Pariwisata dan ekonomi kreatif sebagai penggerak ekonomi Bali juga terpusat di wilayah ini. Sebanyak $65 \%$ dari 4.874 buah fasilitas pariwisata Bali baik bintang dan non-bintang berada di wilayah SARBAGITA. Dilihat dari sisi ketenagalistrikan, 65\% dari 1.081.694 konsumen PLN Bali juga terkonsentrasi di bagian selatan Bali dan menyumbang $51 \%$ dari 5,7 triliun $\mathrm{kWh}$ penjualan energi listrik Bali. Karena berbagai indikator tersebut wilayah SARBAGITA dipilih sebagai fokus untuk menilai bagaimana potensi PLTS Atap di Bali.

Data yang digunakan dalam kajian ini diambil dari sumber-sumber berikut. Data kondisi ketenagalistrikan, ekonomi, dan demografi Bali diambil dari Kementerian ESDM, PT PLN (Persero) UID Bali, Badan Pusat Statistik Provinsi Bali, serta publikasi ilmiah. Sedangkan data primer diperoleh melalui forum diskusi dan wawancara dengan pemangku kepentingan EBT khususnya bidang PLTS di Bali.

Potensi energi matahari di Bali diperoleh melalui simulasi perangkat lunak RETScreen Expert dan Helioscope. Luasan atap dari pemangku kepentingan yang diidentifikasi dalam kajian ini diestimasi dengan metode generik menggunakan citra satelit Google Earth.

Dua skenario potensi berdasarkan persentase pemanfaatan luas atap dilakukan untuk mengetahui potensi daya PLTS Atap jika atap bangunan milik pemangku kepentingan dimanfaatkan untuk pemasangan PLTS. Skenario tersebut adalah pemanfaatan luas atap $25 \%$ dan $60 \%$ dari luas atap keseluruhan. 


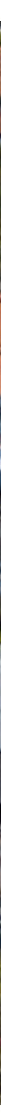

Untuk mengetahui berbagai kendala yang menyebabkan lambatnya perkembangan PLTS di Bali dan khususnya PLTS Atap, dilakukan melalui forum diskusi dengan mengundang pemangku kepentingan dan mendiskusikan faktor-faktor yang menyebabkan lambatnya capaian PLTS di Bali. Di samping itu, Tim Peneliti juga mendatangi pemangku kepentingan untuk melakukan wawancara sehingga diperoleh informasi terkait kendala perkembangan PLTS di Bali.

Data yang telah dikumpulkan kemudian dianalisis dan digunakan untuk menyusun Peta Jalan Pembangunan PLTS Atap di Bali menuju tercapainya kapasitas 108 MW pada tahun 2025. Di samping itu, juga disusun rekomendasi tentang bagaimana mengatasi tantangan pengembangan PLTS Atap di Bali dan potensi kerjasama pemangku kepentingan dapat berkontribusi untuk mencapai target tersebut.

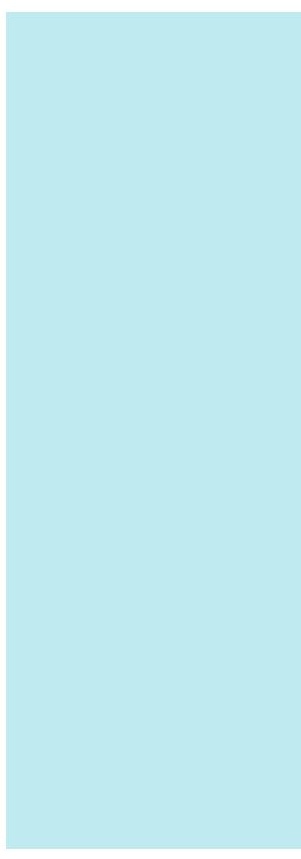




\section{3.}

\section{Kondisi Geografis Bali}

Bali adalah sebuah kepulauan kecil yang terdiri dari empat pulau yaitu pulau Bali, pulau Nusa Penida, pulau Nusa Lembongan, dan pulau Nusa Ceningan. Luas total daratan wilayah administratif Bali adalah 5.637 kilometer persegi. Berdasarkan data sensus penduduk tahun 2010, jumlah penduduk Bali adalah

Luas Wilayah dan Jumlah Penduduk Bali 2010

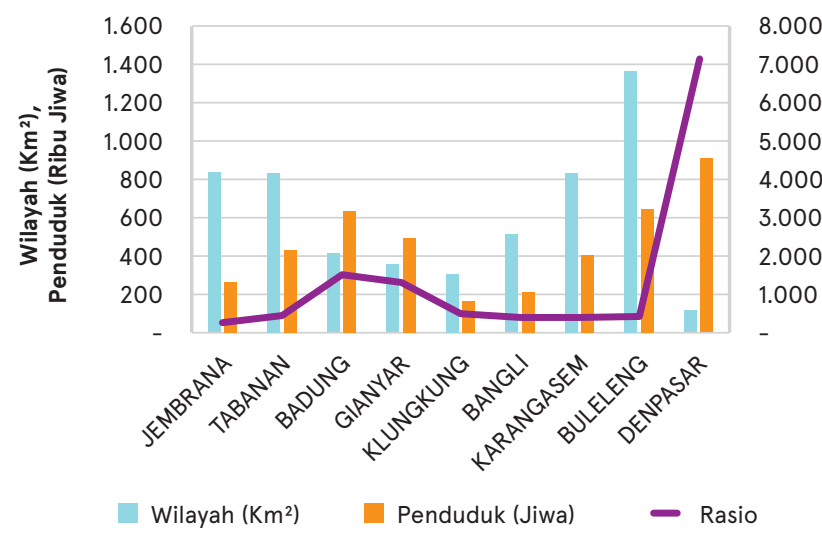

4.246.500 juta jiwa yang tersebar di 8 wilayah Kabupaten/Kota. Grafik luas wilayah Kabupaten/ Kota dan jumlah penduduknya diperlihatkan pada Gambar 4. Terlihat bahwa penduduk Bali sebanyak $59 \%$ berada di wilayah SARBAGITA.

Sebaran Penduduk di Bali 2010

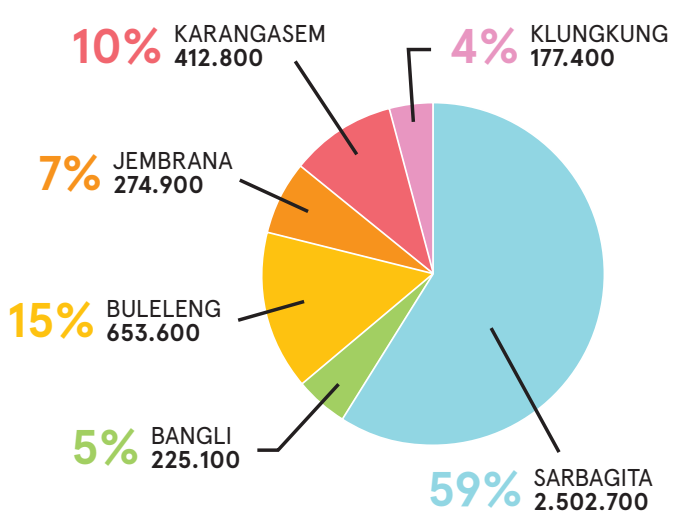

Gambar 4. Luas wilayah Kabupaten/Kota di Bali dan penduduknya 
Perekonomian Bali sangat bergantung kepada sektor pariwisata dan industri kreatif. Dua sektor ini telah mendukung perekonomian di Bali dan ke depan peran ini akan makin diperkuat. Sektor pariwisata sangat erat kaitannya dengan akomodasi serta industri makanan dan minuman. Sektor akomodasi ini terdiri

\section{Jumlah Akomodasi Wisata Bali 2017}

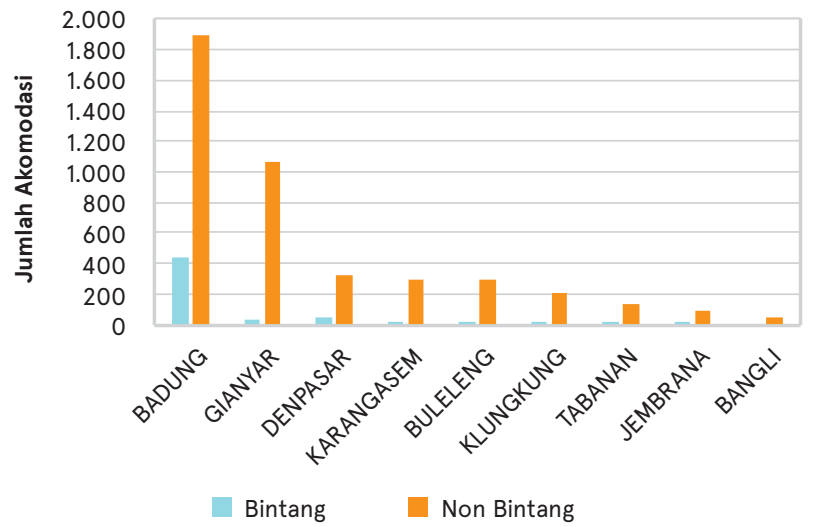

dari hotel, resort, villa, tempat hiburan, dan bentukbentuk akomodasi wisata yang terus berkembang. Sebaran akomodasi wisata di Bali berpusat di wilayah Bali Selatan atau berada dalam wilayah SARBAGITA. Sebaran ketersediaan akomodasi wisata di Bali diperlihatkan pada Gambar 5.

Gambar 5. Akomodasi wisata di Bali

Kunjungan wisatawan baik mancanegara maupun Nusantara ke Bali dari tahun ke tahun terus meningkat. Grafik kunjungan wisatawan ke Bali diperlihatkan pada Gambar 6. Kunjungan wisatawan inilah yang berkontribusi terhadap perekonomian Bali karena selama di Bali mereka berbelanja untuk membayar akomodasi, perjalanan, makanan dan minuman, serta souvenir.

\section{Kunjungan Wisatawan ke Bali}

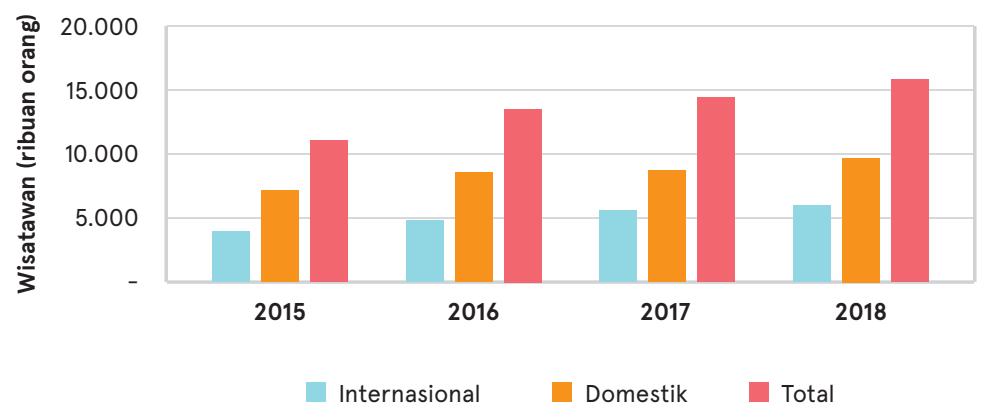

Gambar 6. Jumlah kunjungan wisatawan ke Bali 
Salah satu indikator pembangunan suatu daerah di Indonesia adalah dengan melihat Anggaran Pendapatan dan Belanja Daerah. APBD adalah rencana keuangan tahunan daerah yang merupakan instrumen untuk meningkatkan pelayanan umum dan masyarakat di daerah. APBD dapat memberikan gambaran tentang kebutuhan dan kemampuan setiap daerah sesuai dengan potensi wilayah daerah. Komponen penting dalam APBD adalah Penerimaan

\section{PAD dan Penerimaan Kabupaten/Kota di Bali 2017}

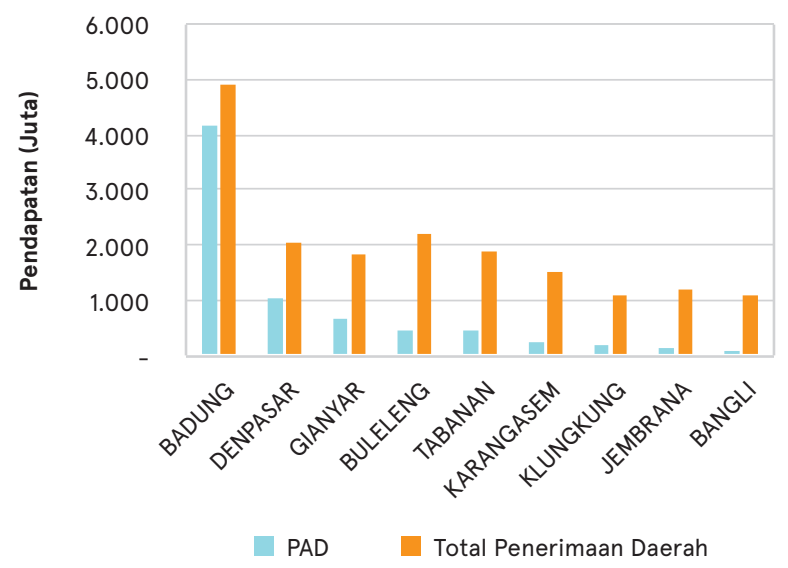

Daerah yang terdiri dari Pendapatan Asli Daerah, Dana Perimbangan, dan Pendapatan Sah Lain. Dari ketiga komponen Penerimaan Daerah ini, PAD merupakan indikator pendapatan yang diterima daerah karena sumber daya yang dimiliki. PAD dan Penerimaan Daerah untuk Kabupaten/Kota di Bali diperlihatkan pada Gambar 7. Dari data tersebut dapat dilihat bahwa wilayah SARBAGITA memiliki potensi ekonomi terbesar di Bali.

\section{Perbandingan PAD SARBAGITA dan Kabupaten di Bali}

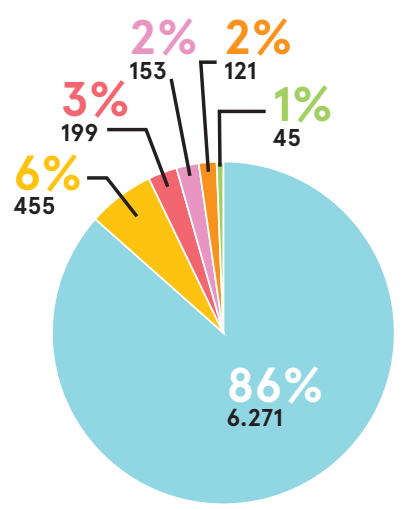

Gambar 7. Penerimaan Daerah Kabupaten/Kota di Bali

Dari indikator-indikator yang telah ditunjukkan di atas dapat dilihat bahwa wilayah SARBAGITA memiliki karakteristik yang sangat mendukung untuk penerapan PLTS Atap pada tahap awal ini. Karakteristik itu antara lain: ketersediaan bangunan yang banyak dan kemampuan ekonomi yang lebih baik dibanding wilayah lain di Bali. 


\section{4.}

\section{Sistem \\ Ketenagalistrikan Bali}

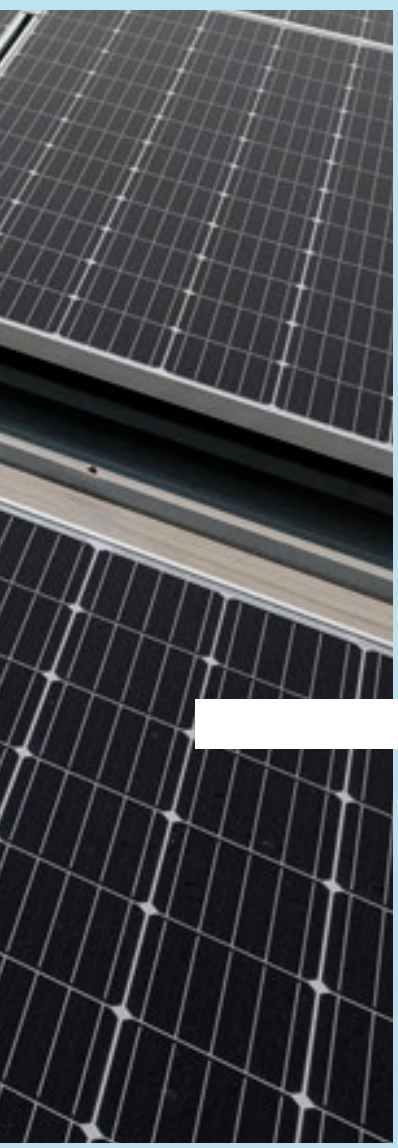

Bali adalah sebuah kepulauan kecil yang terdiri dari empat pulau yaitu Bali, Nusa Penida, Nusa Lembongan, dan Nusa Ceningan. Luas total kepulauan Bali adalah 5.600 kilometer persegi dengan jumlah penduduk sebanyak 4,3 juta jiwa. Secara ekonomi, Bali sangat bergantung pada sektor pariwisata dan industri kreatif. Pada tahun 2017, jumlah wisatawan yang berkunjung ke Bali adalah sekitar 13,5 juta wisatawan dan sekitar $40 \%$ adalah wisatawan mancanegara. Perkembangan pariwisata telah berhasil meningkatkan kesejahteraan masyarakat Bali dan perkembangan pariwisata juga yang menyebabkan peningkatan kebutuhan energi listrik.

Kebutuhan energi listrik di Bali dipasok oleh PLN Unit Induk Distribusi Bali dengan sistem kelistrikan yang ditopang oleh pembangkit listrik berbahan bakar gas PLTG Pesanggaran 125,5 MW, pembangkit berbahan bakar minyak PLTG Gilimanuk 133,8 MW, PLTG Pemaron 97,6 MW, PLTD Pesanggaran 51 MW, PLTD Nusa Penida 3,7 MW, dan pembangkit berbahan bakar batubara PLTU Celukan Bawang 380 MW, serta kabel laut Jawa Bali 300 MW. Total kapasitas pembangkitan sistem Bali pada tahun 2018 adalah 1.091,6 MW. Sementara itu, beban puncak Bali pada tahun 2018 adalah 872 MW. Rasio elektrifikasi Bali sudah 100\% artinya semua rumah tangga di Bali sudah mendapatkan akses tenaga listrik.

Sistem ketenagalistrikan Bali adalah sistem tenaga listrik yang memasok kebutuhan energi listrik di Bali dan merupakan bagian dari sistem ketenagalistrikan Jawa Bali. Sistem Jawa dan Bali terhubung melalui kabel bawah laut di Selat Bali. Sistem ketenagalistrikan Bali dapat dilihat pada Gambar 8. 


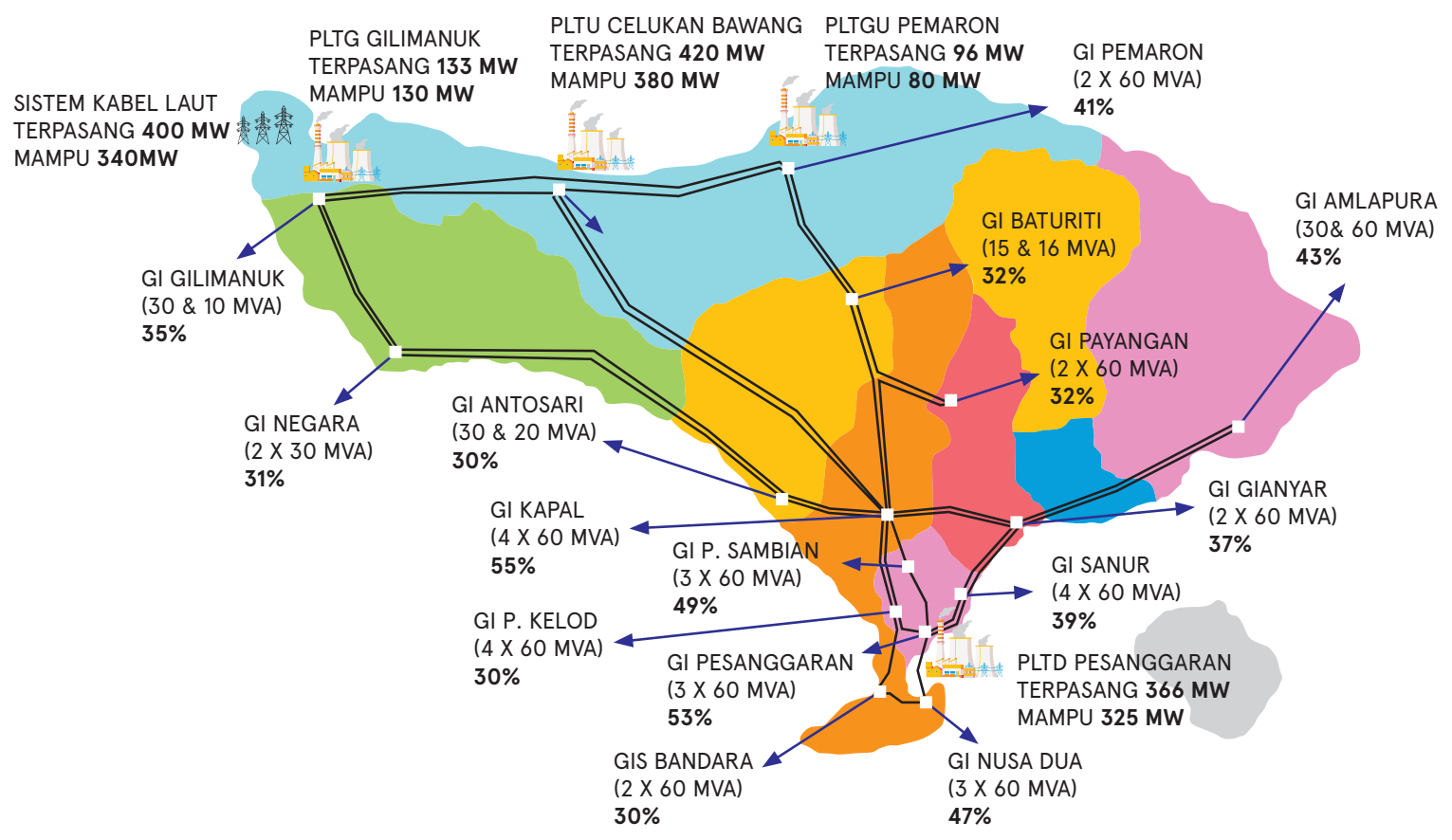

Gambar 8. Sistem kelistrikan Bali

Sistem Bali terdiri dari beberapa pembangkit yang terdiri dari pembangkit berbahan bakar gas, minyak, dan batubara. Bauran pembangkitan tenaga listrik adalah komposisi bahan bakar atau sumber energi alam yang digunakan dalam pembangkitan tenaga listrik. Bauran pembangkitan tenaga listrik Bali tahun 2019 dan rencana pengembangan 2025 berdasarkan data PLN diperlihatkan pada Gambar 9.

\section{Bauran Pembangkitan Tenaga Listrik Bali 2017 (1.437 MW)}

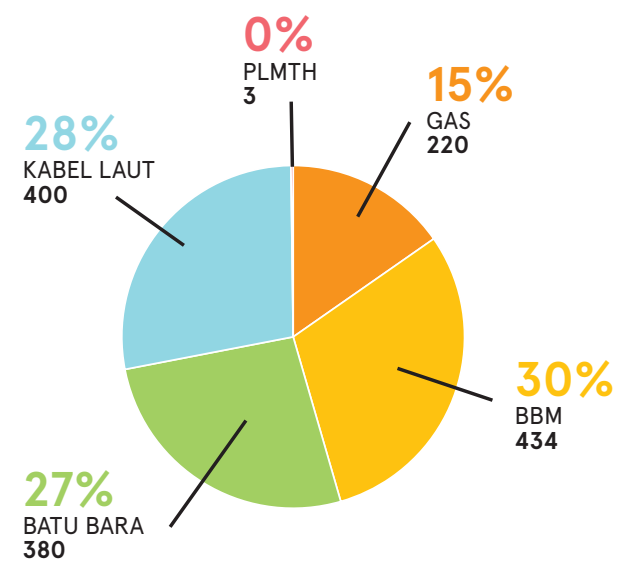

\section{Bauran Pembangkitan Tenaga Listrik Bali 2025 (2.594 MW)}

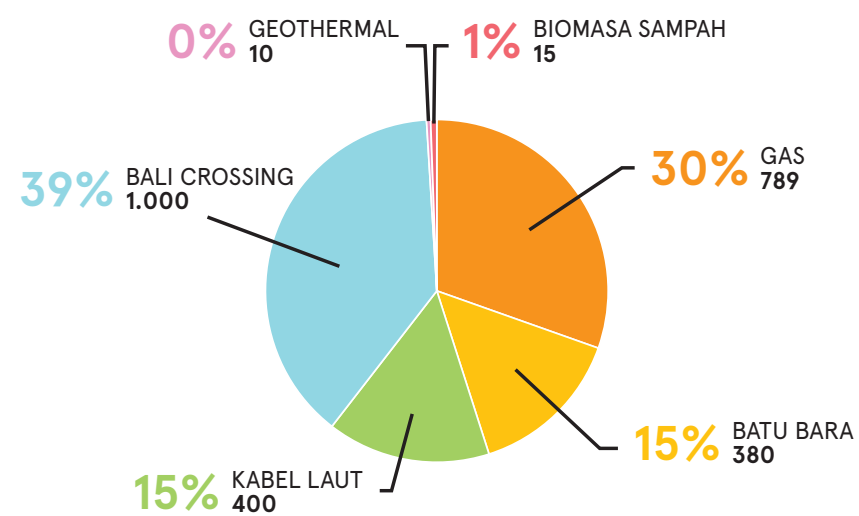


Daya listrik yang dibangkitkan sebesar $1.437 \mathrm{MW}$ tersebut didistribusikan melalui jaringan ke seluruh Bali. Jaringan kelistrikan Bali terdiri dari 1.050 kilometer jaringan transmisi bertegangan $150 \mathrm{KV}$, 458 kilometer Jaringan Tegangan Menengah, dan 524 kilometer Jaringan Tegangan Rendah. JTR adalah jaringan yang terhubung dengan pelanggan. Pada tahun 2017 rasio elektrifikasi Bali sudah 100\% yang artinya semua rumah tangga di Bali sudah mendapat akses tenaga listrik.

Jumlah Pelanggan PLN Kabupaten/Kota di Bali 2017

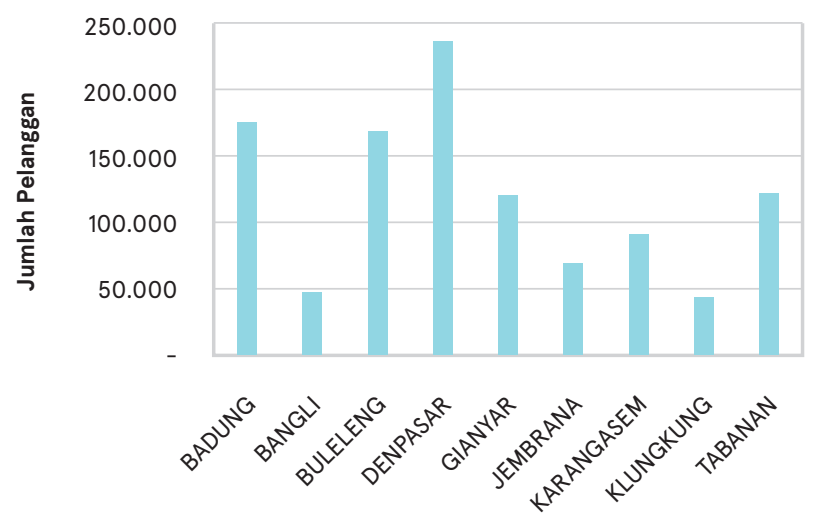

Konsumen tenaga listrik PLN Bali berdasarkan data tahun 2017 adalah sebanyak 1.081 .694 pelanggan. Jumlah pelanggan di Kabupaten/Kota di Bali diperlihatkan pada Gambar 10. Jumlah pelanggan PLN di Kota Denpasar, Kabupaten Badung, Kabupaten Gianyar, dan Kabupaten Tabanan atau yang disebut SARBAGITA adalah sebanyak 657.331 pelanggan. Angka ini merupakan $61 \%$ dari seluruh pelanggan PLN di Bali. Jadi bisa kita lihat, jumlah pelanggan PLN Bali terpusat di wilayah Bali Selatan.

\section{Sebaran Pelanggan PLN Bali 2017}

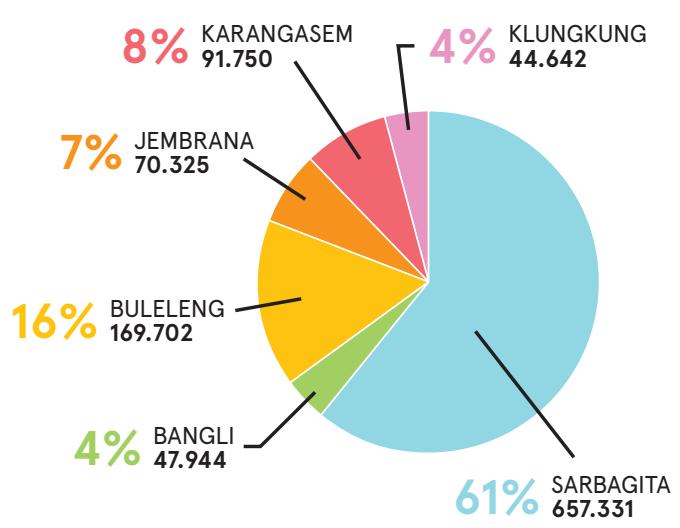

Gambar 10. Pelanggan PLN di Bali Tahun 2017

Berdasarkan indikator demografi, ekonomi, dan energi seperti di paparkan di atas maka fokus kajian potensi PLTS Atap yang dilaporkan disini adalah potensi yang ada di wilayah Bali Selatan atau wilayah SARBAGITA. 


\section{5.}

\section{Pembangkit Listrik Tenaga Surya}

Energi listrik yang dihasilkan oleh sebuah PLTS dipengaruh oleh beberapa faktor antara lain: potensi matahari di lokasi pembangkit, teknologi PLTS yang digunakan, serta pengoperasian dan pemeliharaan PLTS. Ketiga faktor ini harus dilihat sebagai sebuah paket yang lengkap dalam membangun sebuah PLTS agar dapat berfungsi secara efektif dan berkelanjutan. Berikut adalah komponen dari Pembangkit Listrik Tenaga Surya:

MODUL SURYA
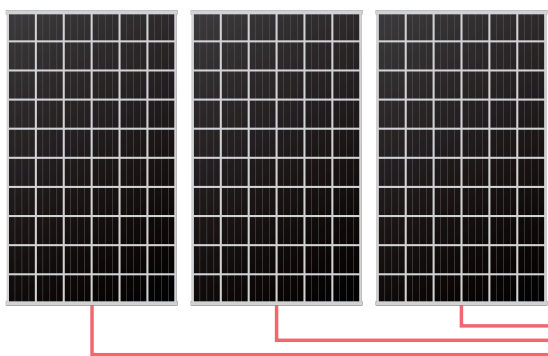

JARINGAN PLN

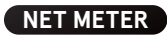

\section{BEBAN} LISTRIK
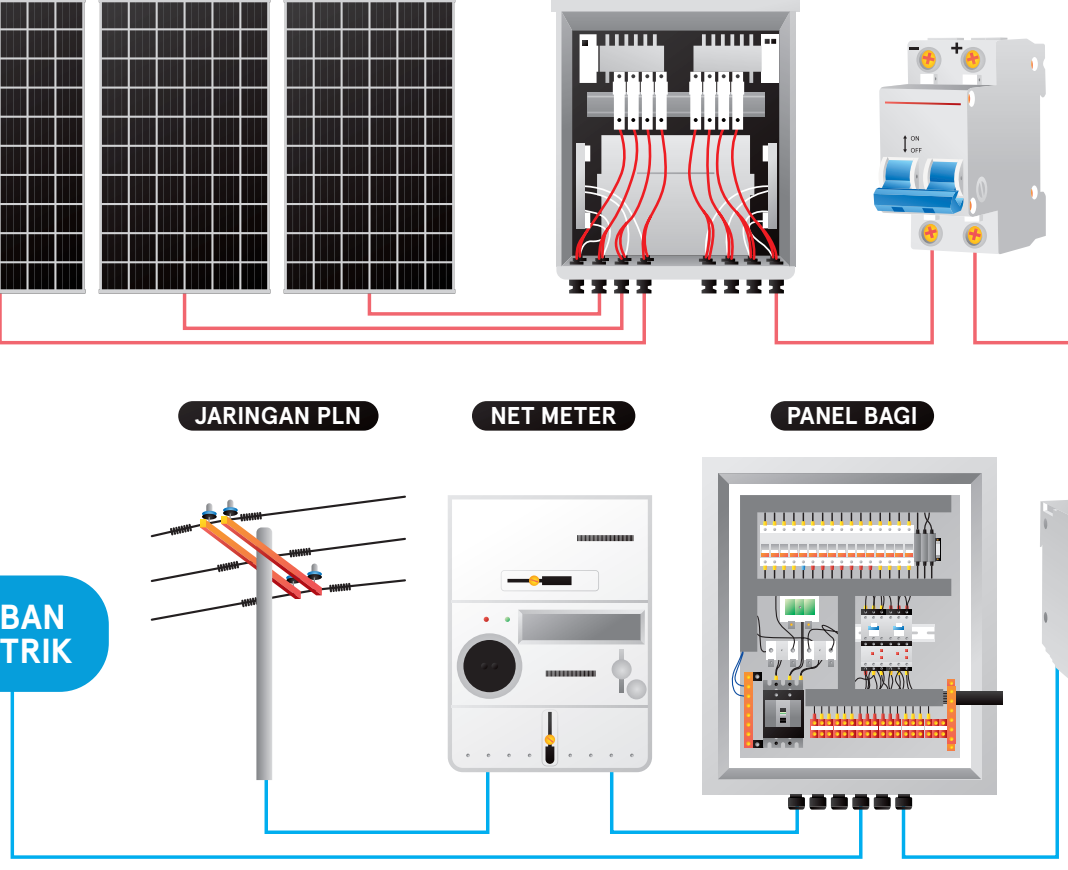

PEMUTUS AC

Gambar 11. Skematik Pembangkit Listrik Tenaga Surya 
Potensi matahari adalah indikasi bagaimana tenaga matahari diterima di suatu lokasi di permukaan bumi. Pendekatan yang bisa dilakukan untuk mengetahui potensi matahari tersebut antara lain dengan melakukan pengukuran langsung dengan alat ukur atau memperkirakan potensinya berdasarkan parameter cuaca yang diperoleh dari data satelit. Simulasi dengan perangkat lunak RETScreen dan Helioscope menunjukkan potensi energi matahari di pusat Kabupaten/Kota di Bali berkisar antara 4,01 $6,13 \mathrm{kWh} / \mathrm{m}^{2} /$ hari dengan rata-rata $4,89 \mathrm{kWh} / \mathrm{m}^{2} /$ hari. Karena Bali adalah pulau yang cukup kecil maka perbedaan potensi energi matahari di 8 Kabupaten/ Kota tidak terlalu besar.

Sebagai wilayah dengan iklim tropis, Provinsi Bali memiliki potensi energi bersih yang sangat besar, terutama energi matahari, untuk memenuhi kebutuhan listrik masyarakatnya. Dibandingkan energi bersih lainnya, energi solar di Provinsi Bali memiliki potensi yang paling tinggi, yaitu sekitar 98\% dari total potensi energi bersih yang terdapat di Bali. Berdasarkan penelitian yang dilakukan oleh Sah, B.P. dan Wijayatunga, P. (2017) dalam Asian Development Bank Sustainable Environment Working Paper Series, Bali memiliki iradiasi solar berkisar 1,490 hingga $1,776 \mathrm{kWh} / \mathrm{m}^{2} /$ tahun, atau melebihi standar yang diberlakukan di Eropa untuk kelayakan proyek energi surya, yaitu $900 \mathrm{kWh} / \mathrm{m}^{2} /$ tahun. Dengan menggunakan sistem permodelan pemetaan, dapat diketahui bahwa total potensi energi surya di Provinsi Bali dapat mencapai 113,436.5 GWh per tahun, di mana jauh melebihi jumlah permintaan energi penduduknya pada tahun 2027, yaitu 10,014 GWh per tahun.

\section{Potensi Energi Matahari di Kabupaten/ Kota di Bali}

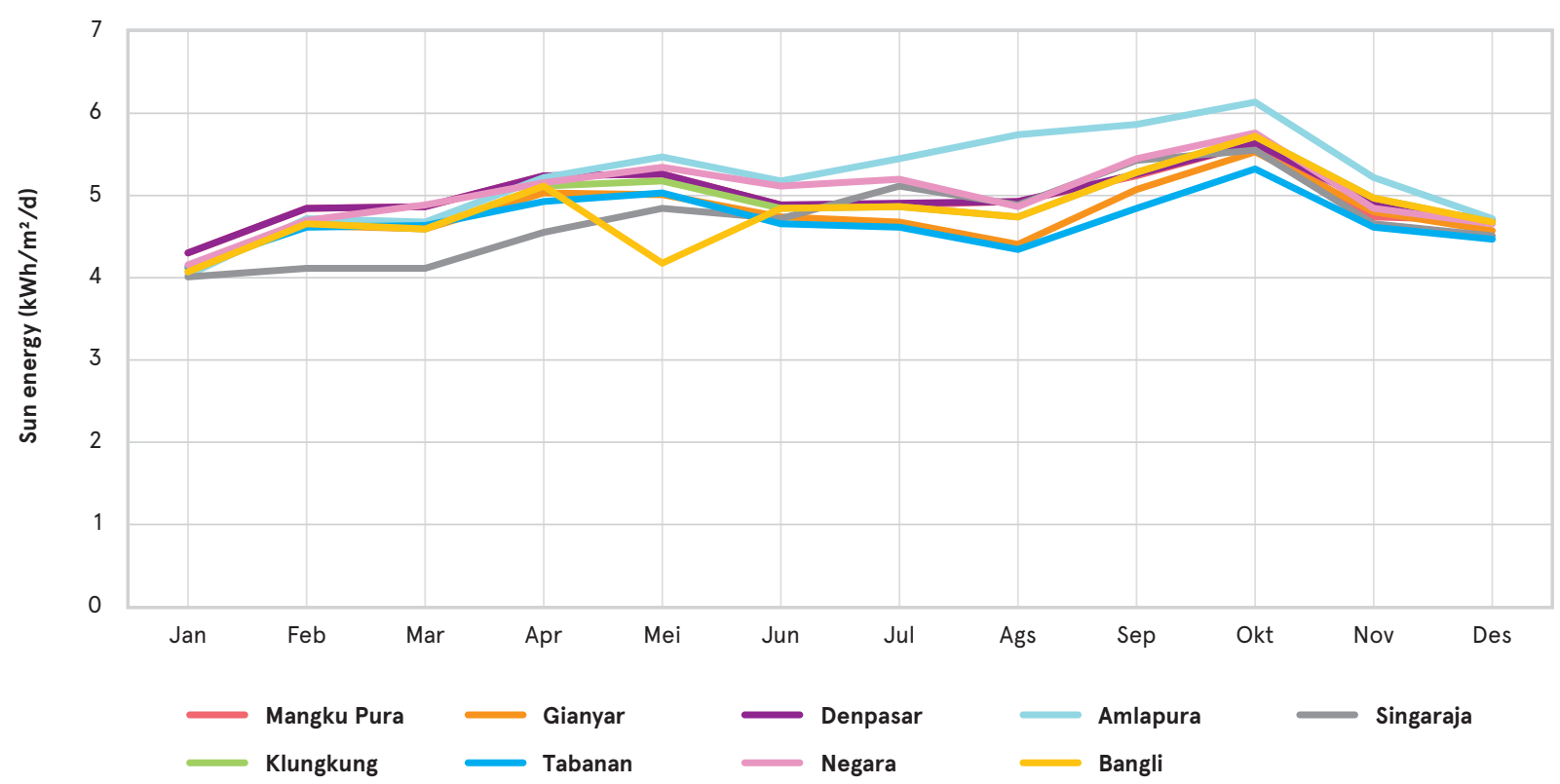

Gambar 12. Indeks radiasi matahari di pusat Kabupaten/Kota di Bali 
Teknologi PLTS sekarang ini sudah sangat maju sehingga efisiensi keseluruhan sangat baik dan secara ekonomis mulai kompetitif. Faktor teknologi dan ekonomi di tambah dengan potensi tenaga matahari yang tersedia dimana-mana menjadi faktor penting pesatnya peningkatan penerapan PLTS di dunia dan termasuk di Indonesia. Pemanfaatan sistem PLTS di Indonesia sudah cukup beragam mulai dari SHS hingga sistem skala besar.

\section{Solar Home System}

Solar Home System adalah pemanfaatan teknologi PLTS pertama di dunia termasuk juga di Indonesia. Saat ini, SHS dikemas dengan komponen-komponen sesuai dengan perkembangan teknologi terakhir yang disebut Lampu Tenaga Surya Hemat Energi dan dipasang di banyak rumah-rumah penduduk

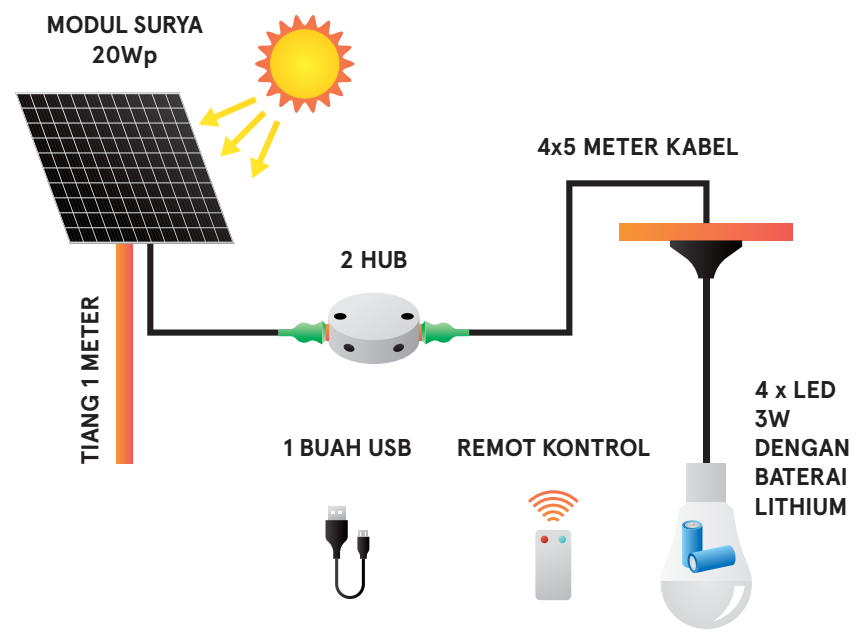

yang berada di luar jangkauan PLN sebagai upaya penyediaan akses energi listrik dus rasio elektrifikasi nasional. Sebuah sistem LTSHE terdiri dari satu buah modul surya $20 \mathrm{Wp}$, baterai Lithium-lon, kabel USB charger, remote control, dan empat buah lampu LED 3 W [Gambar 13].

Gambar 13. Skematik sistem LTHSE dan instalasinya di rumah terpencil

PLTS off-grid adalah PLTS yang dibangun untuk melayani kebutuhan energi listrik suatu masyarakat atau komunitas yang belum terjangkau oleh jaringan PLN [Gambar 14]. 


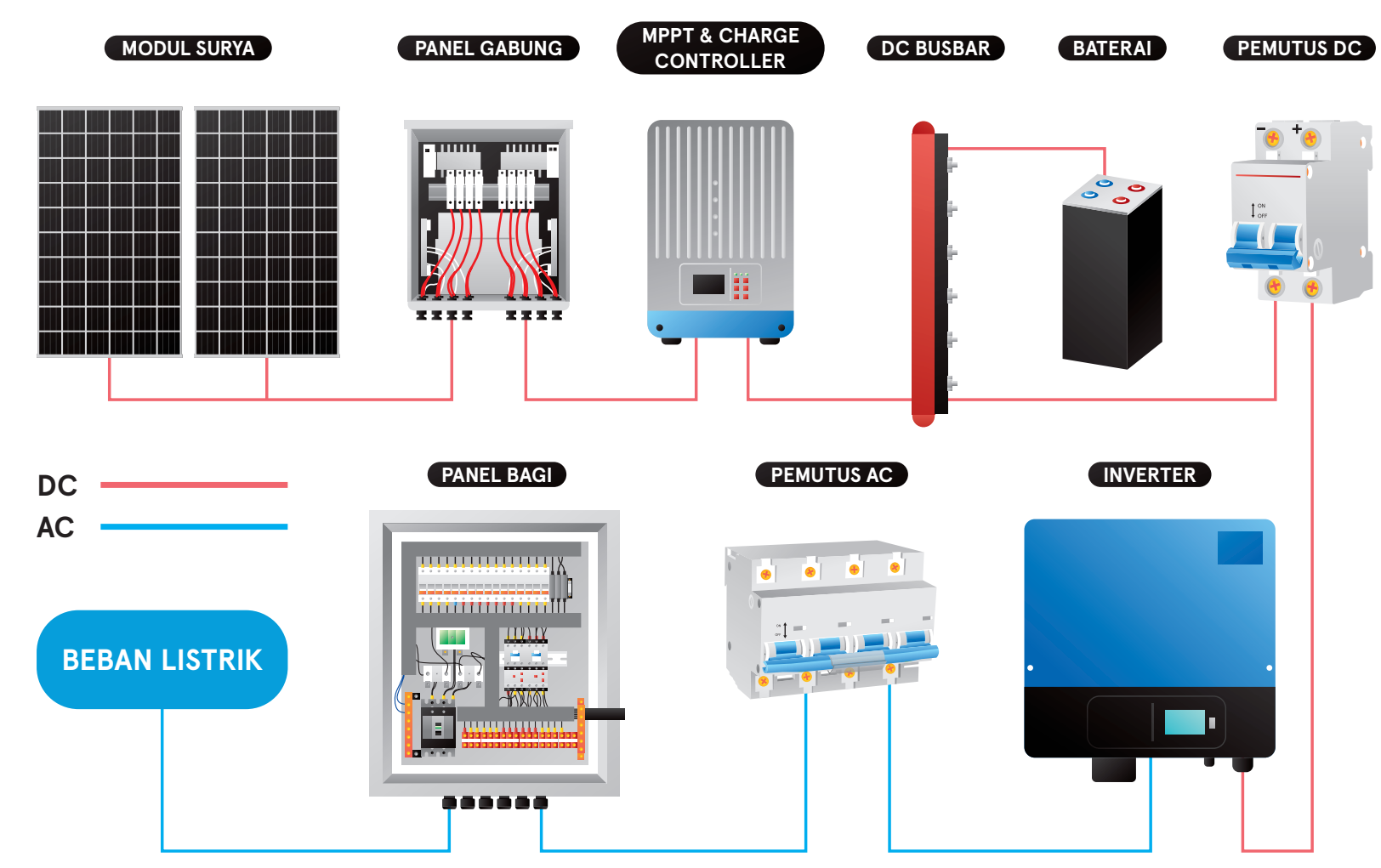

Gambar 14. Skematik PLTS off-grid

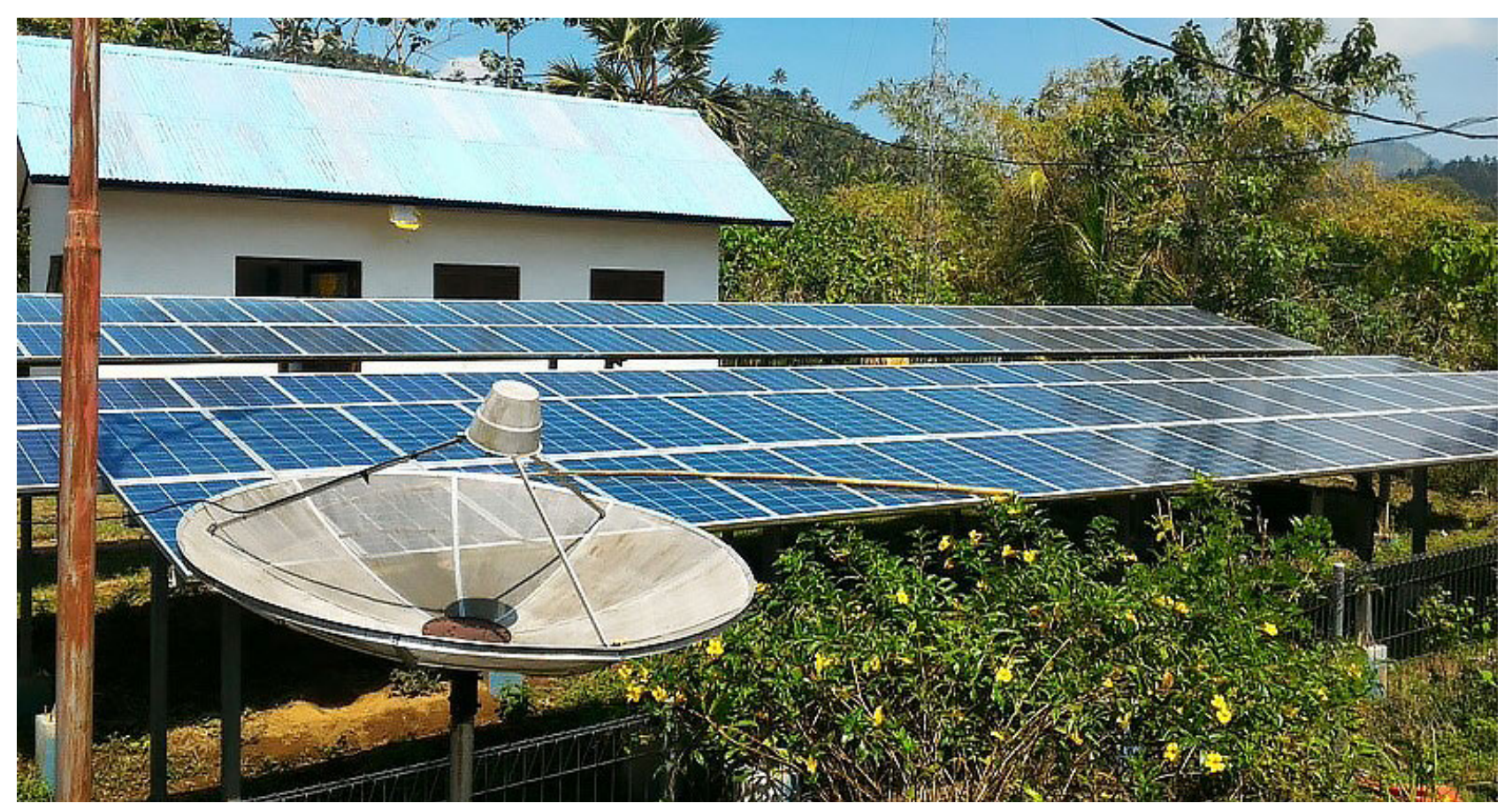

Gambar 15. PLTS off-grid untuk komunitas di daerah terpencil 


\section{PLTS on-grid}

PLTS on-grid adalah PLTS yang terhubung dengan jaringan PLN. PLTS on-grid beroperasi pada siang hari dan jika jaringan PLN beroperasi secara normal. Jika PLN tidak beroperasi dikarenakan ada gangguan atau pemeliharaan, maka PLTS on-grid juga tidak akan beroperasi kecuali dirancang untuk beroperasi dalam islanding mode atau mode terisolasi dari jaringan PLN. Berdasarkan tempat pemasangan, PLTS on-grid bisa dikelompokkan menjadi empat, yaitu: PLTS ground mount atau PLTS di atas permukaan tanah, 2) floating PV atau PLTS permukaan air, 3) building integrated PV atau PLTS terintegrasi pada bangunan, dan 4) PLTS Atap. Dalam konteks Bali, PLTS yang sudah dan berpotensi untuk dikembangkan adalah PLTS ground mount dan PLTS Atap.

\section{PLTS on-grid ground mount}

PLTS on-grid ground mount atau PLTS terkoneksi jaringan di atas tanah ini adalah aplikasi PLTS berkapasitas besar biasanya di atas $500 \mathrm{kWp}$.

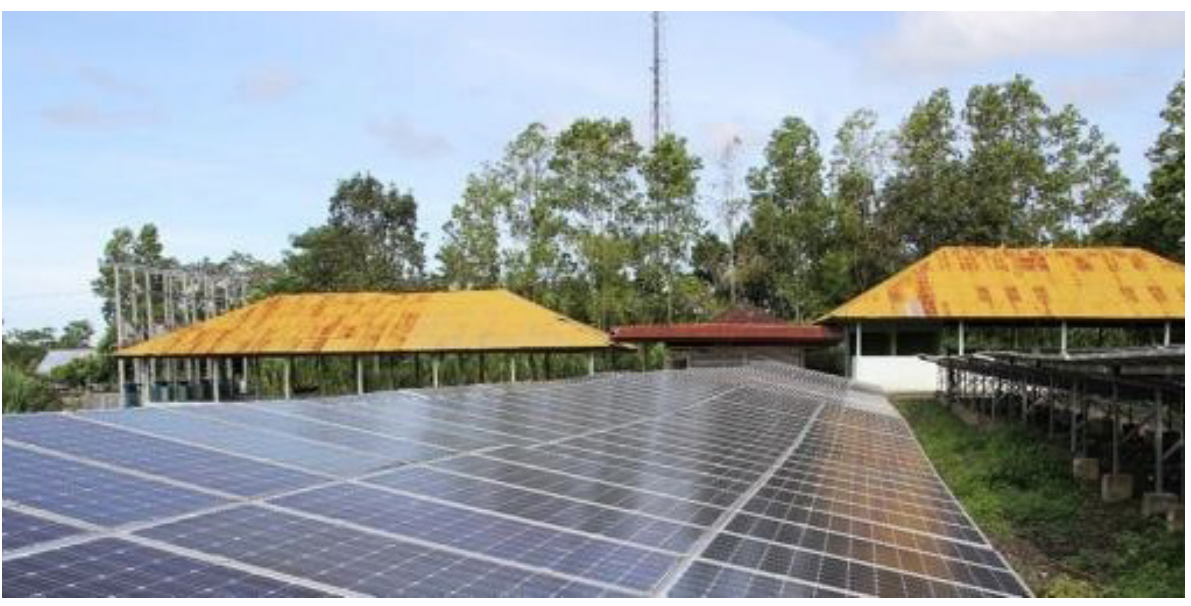

Gambar 16. PLTS on-grid ground mount di Desa Kayubihi kapasitas 1 MWp 


\section{PLTS Atap}

PLTS Atap adalah PLTS yang terpasang di atas atap bangunan baik atap bangunan berbentuk limas dengan genteng maupun atap datar dengan dak beton. PLTS Atap adalah PLTS yang dirancang untuk mengurangi pasokan energi listrik dari PLN atau menghasilkan energi listrik sendiri.

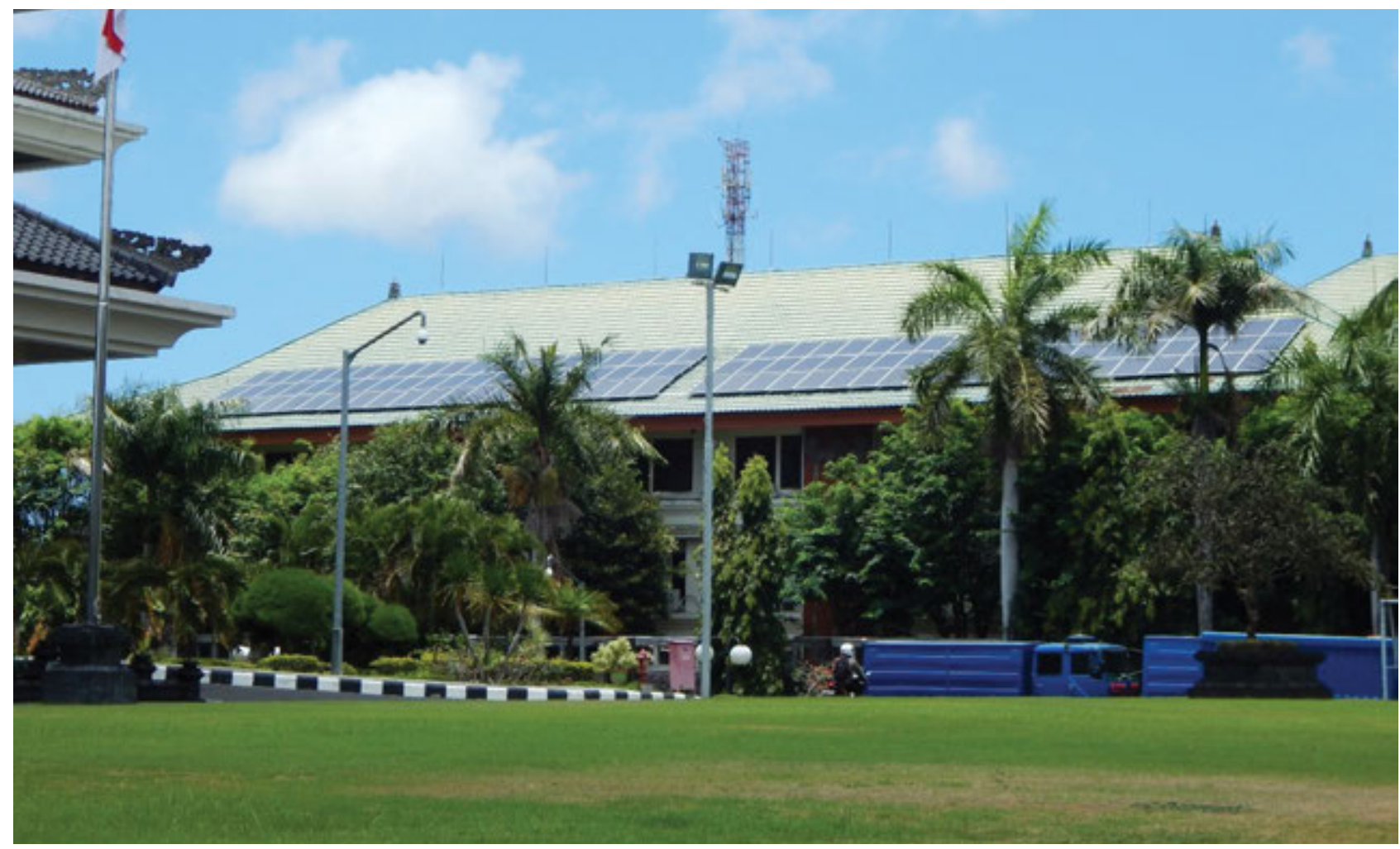

Gambar 17. Aplikasi tipikal PLTS Atap

Dari paparan di atas dapat dilihat bahwa saat ini teknologi PLTS sudah siap untuk menjadi bagian dari portofolio pembangkitan tenaga listrik di Bali. Potensi matahari juga sangat besar dan tersebar secara merata di seluruh wilayah Bali. Dan yang terpenting bahwa masyarakat sudah melihat adanya berbagai pilot proyek yang sudah dibangun di Bali. 


\section{6.}

\section{Tantangan Pengembangan PLTS di Bali}

PLTS Atap sudah mulai berkembang di Bali seperti dipaparkan sebelumnya tapi progres kapasitas terpasang PLTS di Bali sampai saat ini masih jauh dibawah target PLTS 2025 yang telah ditetapkan. Berikut adalah beberapa faktor yang menyebabkan lambatnya perkembangan PLTS di Bali.

Pembangunan PLTS secara umum bisa dibagi dua yaitu ground mount system dan rooftop atau building integrated. Pembangunan ground mount system memerlukan lahan tanah baru sebagai tempat pemasangan arai surya. Kapasitas PLTS berbanding lurus dengan luas lahan yang digunakan. Makin besar kapasitas PLTS maka makin luas lahan yang diperlukan. Sebagai contoh, ground mount system PLTS 1 MWp Bangli dan PLTS 1 MWp Karangasem masing-masing memerlukan lahan seluas 1.2 hektar. Bagi Bali yang merupakan pulau kecil dan dengan kepadatan penduduk yang cukup tinggi serta dibatasi oleh koefisien kawasan hijau maka pembangunan yang menyebabkan terjadinya alih fungsi lahan dari lahan pertanian menjadi lahan pembangunan PLTS menjadi tidak mudah dan memerlukan studi yang lengkap. Namun demikian, beberapa wilayah di Bali masih memungkinkan untuk dikembangkan sebagai lokasi PLTS ground mount system berskala besar.

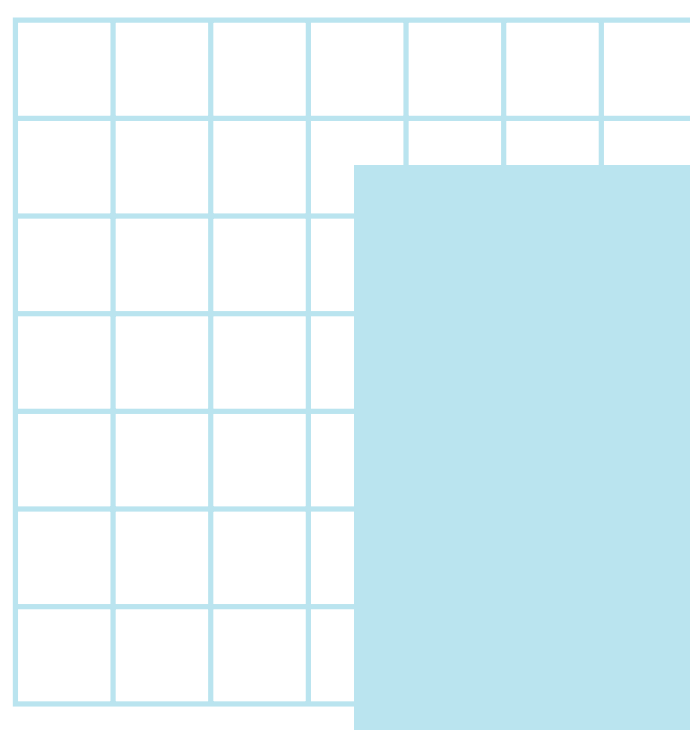

Sebagai contoh, Kabupaten Buleleng, Karangasem, dan Klungkung khususnya di Nusa Penida memungkinkan untuk dikembangkan ground mount system. Sedangkan bagi wilayah yang lain akan lebih sulit akibat kebutuhan lahan untuk perumahan dan perkembangan industri pariwisata yang juga berbasis penyediaan akomodasi. Mengingat kondisi geografis ini maka bagi Bali, potensi PLTS Atap menjadi salah satu komponen penting dalam portofolio pengembangan PLTS.

Perkembangan teknologi PLTS menyebabkan harga sistem PLTS dari tahun ke tahun mengalami penurunan. Walaupun begitu, bagi Indonesia dan khususnya Bali, harga sistem PLTS masih merupakan salah satu kendala belum berkembangnya PLTS Atap di Bali. Harga investasi awal PLTS Atap untuk wilayah Bali berkisar antara 1.200 - 1.300 USD/ kWp tergantung lokasi dan kondisi atap bangunan. Harga ini tergolong mahal bagi sebagian besar masyarakat sehingga perlu diidentifikasi model finansial yang bisa membantu calon pemakai PLTS Atap di Bali.

Secara umum, sampai saat ini belum ada fasilitas kredit untuk pembangunan PLTS Atap. Sementara kalau dilihat begitu banyak lembaga perbankan, 


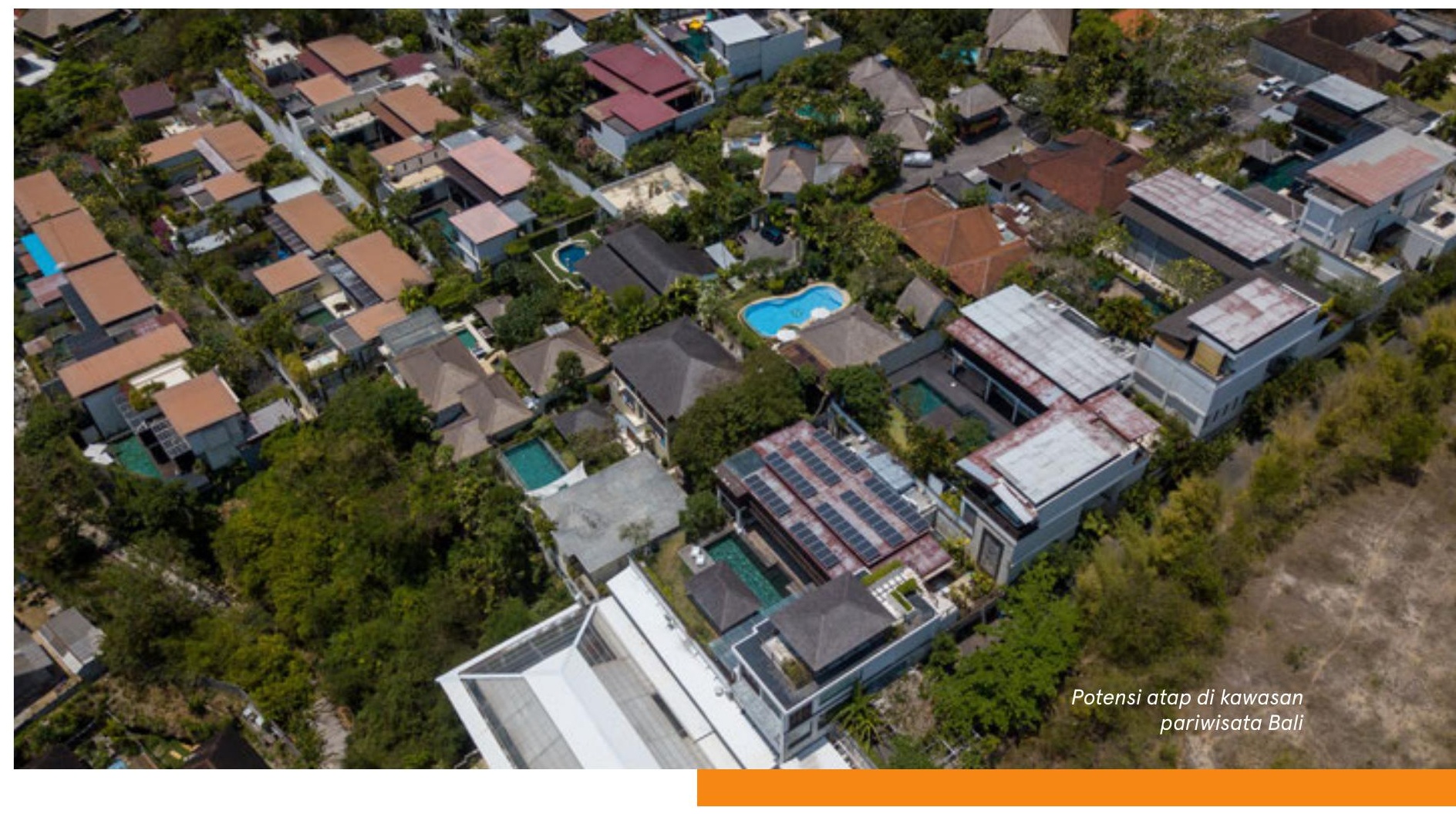

lembaga finansial, dan koperasi namun belum ada secara khusus memberikan fasilitas kredit energi. Secara terbatas sudah ada uji coba pemberian kredit energi oleh sebuah koperasi untuk membantu anggotanya membangun PLTS Atap. Hal ini perlu dikembangkan lagi sehingga makin banyak lembaga finansial yang tertarik untuk mendanai investasi PLTS Atap.

Harga jual energi ke PLN atau model akumulasireset dari kWh meter ekspor-impor energi PLTS yang ditetapkan dalam Permen ESDM 49/2018 menurut berbagai kalangan dinilai masih belum menguntungkan dilihat dari sisi investasi. Namun, sesuai dengan tujuan dari PLTS Atap adalah untuk mengurangi pasokan energi dari PLN sehingga PLTS Atap memang belum diarahkan sebagai investasi pembangkitan. Dalam konteks ini, diperlukan sosialisasi agar masyarakat memahami apa tujuan yang ingin dicapai dengan diterapkannya Permen 49/2018.

Salah satu tahapan penting sebelum PLTS Atap bisa dioperasikan adalah penyambungan dengan jaringan listrik PLN. Penyambungan ini merupakan wewenang dari PLN sebagai pemilik jaringan. Dalam proses penyambungan ini perlu dilakukan melalui keterbukaan prosedur dan mekanisme agar Pelanggan yang memiliki PLTS Atap tidak mengalami hambatan dalam partisipasinya ikut membangun PLTS sementara disisi lain PLN sebagai pemilik jaringan tidak mengalami kendala dalam mengoperasikan sistem ketenagalistrikan yang memasok tenaga listrik ke pelanggan di seluruh Bali.

Pulau Bali terletak tidak terlalu jauh dari Pulau Jawa sehingga kebutuhan tenaga teknis yang terkait dengan konstruksi atau pemasangan PLTS hampir semuanya berasal dari Pulau Jawa atau perusahaan atau tenaga teknis yang berkantor di Jawa khususnya Jakarta. Ini juga menjadi salah satu faktor lambatnya perkembangan PLTS Atap di Bali. Setelah konstruksi selesai, kendala pemilik PLTS Atap mengalami kesulitan dalam melakukan pemeliharaan atau perawatan karena untuk melakukan kegiatan ini memerlukan keterampilan tertentu terkait keselamatan. Kontraktor PLTS biasanya fokus pada pekerjaan pemasangan PLTS baru sehingga dalam pengoperasiannya pemilik PLTS harus mencari alternatif yang tidak mudah untuk didapatkan. Hal ini terjadi karena belum berkembangnya ekosistem yang baik di Bali untuk mendukung berkembangnya PLTS yang berkelanjutan. 


\section{7.}

\section{PLTS Rooftop Sebagai Solusi}

PLTS Rooftop adalah salah satu solusi untuk mempercepat perkembangan PLTS di Bali. Hal ini dikarenakan karakteristik geografi dan demografi Bali yang minim lahan luas, serta jumlah penduduk yang cukup besar sehingga terdapat ketersediaan atap rumah atau bangunan juga dalam jumlah besar. Selain

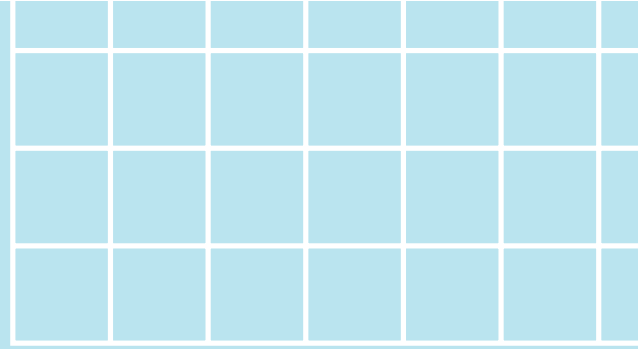

itu, berkembangnya industriberbasis pariwisata di Bali khususnya sektor akomodasi wisata juga menyumbangkan luasan atap yang cukup besar. Atap gedung milik pemerintah, industri, bisnis, lembaga pendidikan, dan juga aset Desa Adat Bali sangat potensial untuk pemanfaatan PLTS Atap.

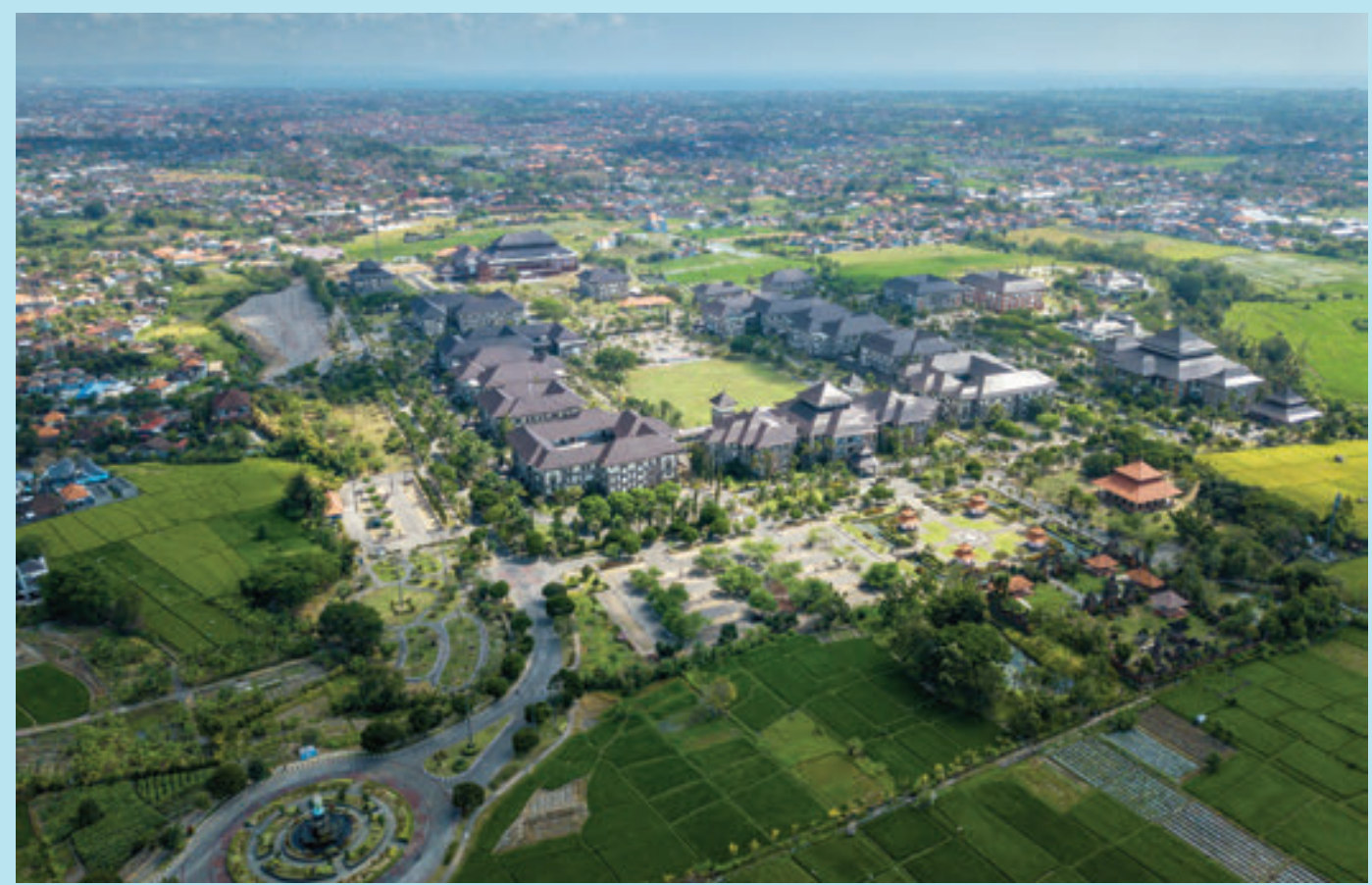

Gambar 18.

Potensi atap bangunan dari kompleks Pusat Pemerintahan Kabupaten Badung

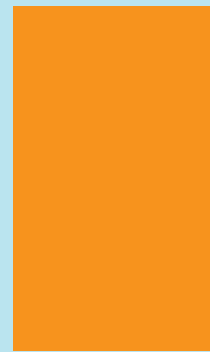




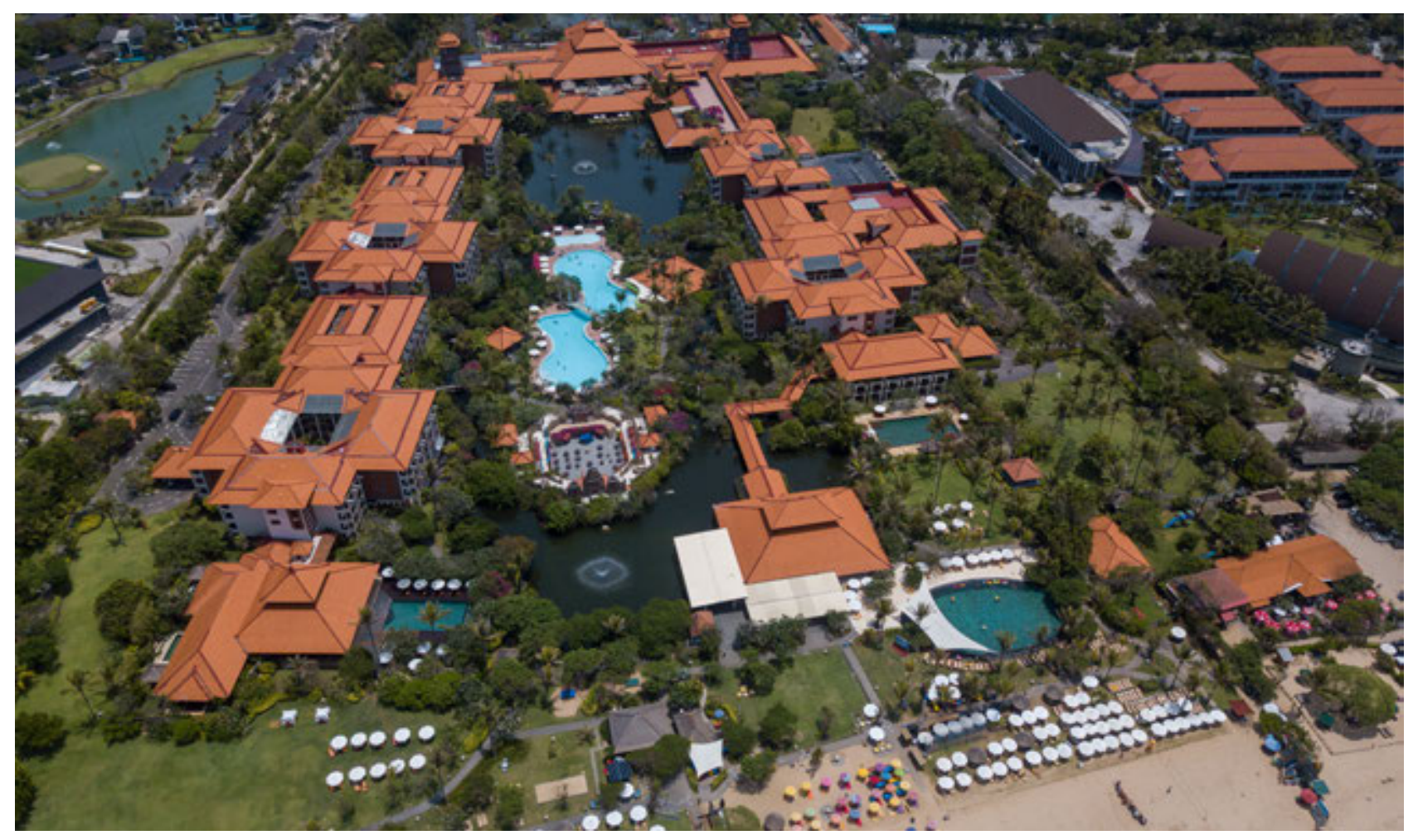

Gambar 19. Potensi atap bangunan Hotel Ayodya Resort Bali di kawasan ITDC Nusa Dua

\section{PLTS Atap Ekisting Di Provinsi Bali}

\section{Pemerintah}

Berbagai pilot proyek PLTS Atap sebenarnya sudah dibangun di Bali baik oleh Pemerintah pusat, Pemerintah Provinsi, Pemerintah Kabupaten/Kota, PLN atau IPP, universitas, industri pariwisata, dan juga masyarakat umum. Hal ini tentu menegaskan bahwa PLTS Atap merupakan sebuah solusi nyata yang perlu disebarluaskan kepada masyarakat untuk mempercepat pembangunan PLTS di Bali.

Pemerintah Pusat melalui Badan Litbang P3TKEBTKE Kementerian ESDM telah bekerjasama dengan Pemerintah Bali dalam mengembangkan pilot proyek PLTS Atap sebagai bagian dari sistem mikrogrid Kantor Gubernur Bali. Prinsip skema kerjasama ini adalah Pemerintah Daerah menyiapkan atap bangunan dan
Kementerian ESDM membangun PLTS di atasnya. PLTS Atap Kantor Gubernur Bali ini berkapasitas 158 kWp dan telah beroperasi untuk mengurangi pasokan energi listrik dari PLN. Foto udara dari PLTS di Kantor Gubernur Bali diperlihatkan pada Gambar 20.

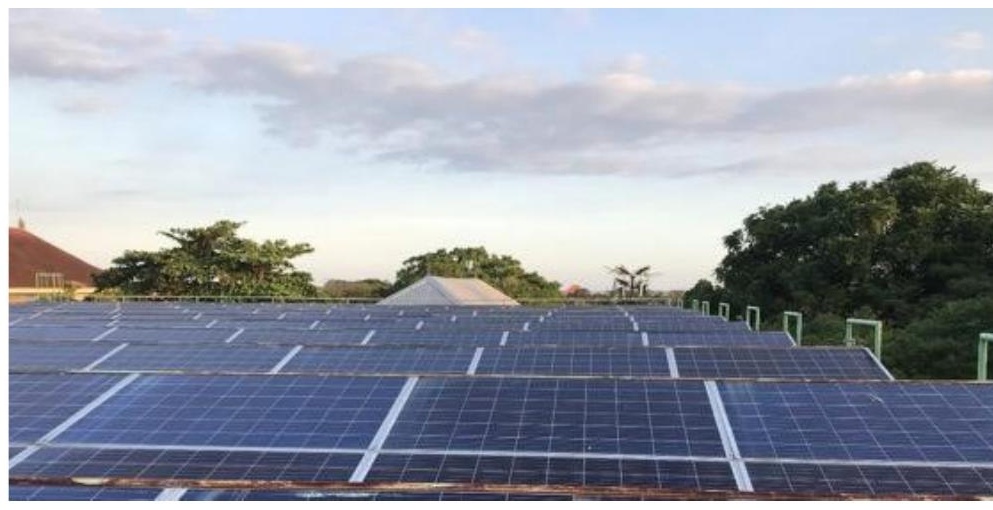

Gambar 20. PLTS Atap 158 kWp di Kantor Gubernur Bali 


\section{Lembaga Pendidikan}

Badan Litbang P3TKEBTKE ESDM juga melakukan kerja sama dengan Universitas Udayana untuk membangun PLTS Atap berkapasitas $26 \mathrm{kWp}$ di atas salah satu ruang kuliah Program Studi Teknik Elektro. PLTS ini juga telah beroperasi dengan cukup baik untuk mengurangi pasokan energi listrik dari jaringan
PLN. Prinsip skema kerja sama ini juga hampir sama dengan model kerjasama ESDM dan Kantor Gubernur Bali, dimana Universitas Udayana menyiapkan atap bangunan dan Badan Litbang P2EBTKE membangun PLTS di atas atap bangunan kampus. Gambar 21 menunjukkan foto udara PLTS Atap di salah satu gedung Teknik Elektro Fakultas Teknik Universitas Udayana.

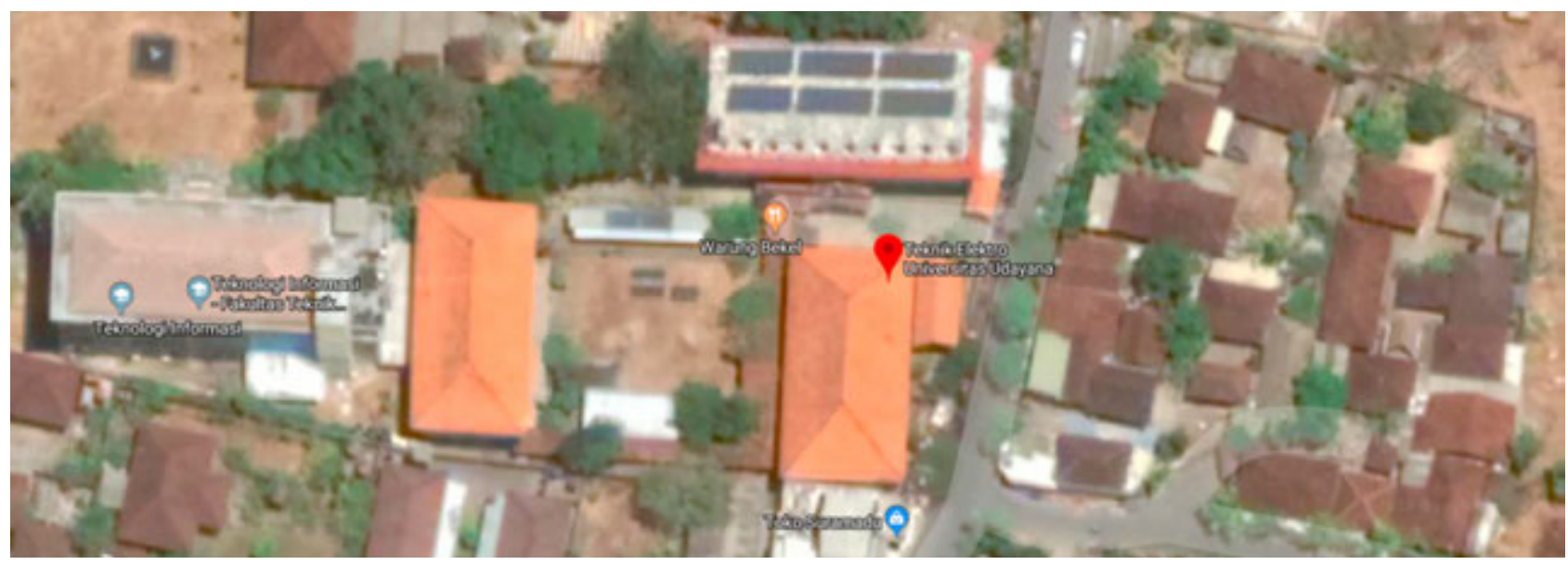

Gambar 21. PLTS Atap $26 \mathrm{kWp}$ di Universitas Udayana

Pemerintah Kota Denpasar juga telah membangun PLTS Atap yang digunakan sebagai catu daya sistem pengolahan limbah bagi masyarakat di salah satu desa di Kecamatan Denpasar Barat. Dalam skema ini Pemerintah Kota Denpasar membangun PLTS di atas salah satu gedung Sekolah Menengah Pertama 4 Denpasar. PLTS dan sistem pengolahan limbah ini dikelola oleh Desa Adat Padang Sambian Kaja. Gambar 22 menunjukkan lokasi PLTS Atap untuk IPAL di Desa Padang Sambian Kaja Denpasar.

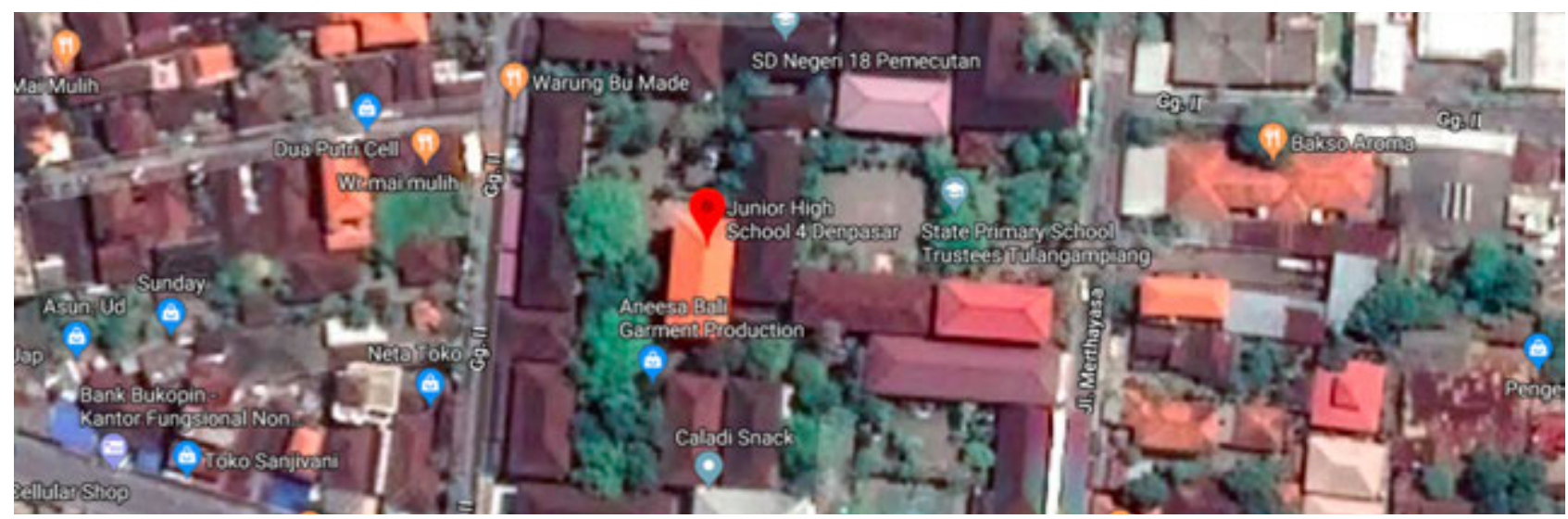

Gambar 22. PLTS Atap untuk instalasi pengolahan limbah masyarakat 


\section{PLN UID Bali}

PLN UID Bali juga telah membangun beberapa pilot proyek PLTS Atap di gedung -gedung nya yang tersebar di seluruh Bali. Pilot proyek PLTS Atap berkapasitas 30 kWp di Kantor UID Bali diperlihatkan pada Gambar 23. PLN Bali juga telah membangun PLTS Atap berkapasitas $10 \mathrm{kWp}$ di salah satu atap bangunan kantor UP3 Bali Selatan.
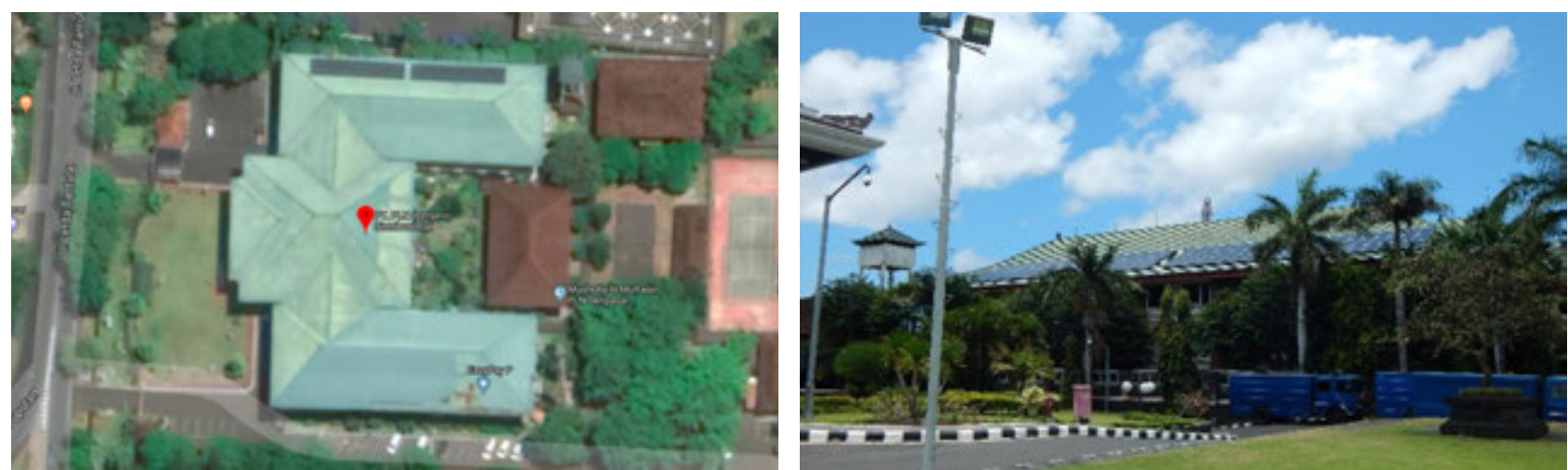

Gambar 23. PLTS Atap di Kantor PLN UID Bali

PT Indonesia Power UP Pesanggaran Bali yang bergerak dibidang pembangkitan tenaga listrik juga telah membangun PLTS Atap sebagai bagian dari upaya untuk membangun portofolio pembangkitan tenaga yang bersih dan berkelanjutan. Indonesia
Power telah membangun PLTS Atap berkapasitas 24 kWp pada tahun 2016 dan PLTS Atap berkapasitas 7,5 kWp pada tahun 2018. Gambar 24 menunjukkan PLTS Atap di Indonesia Power Pesanggaran.

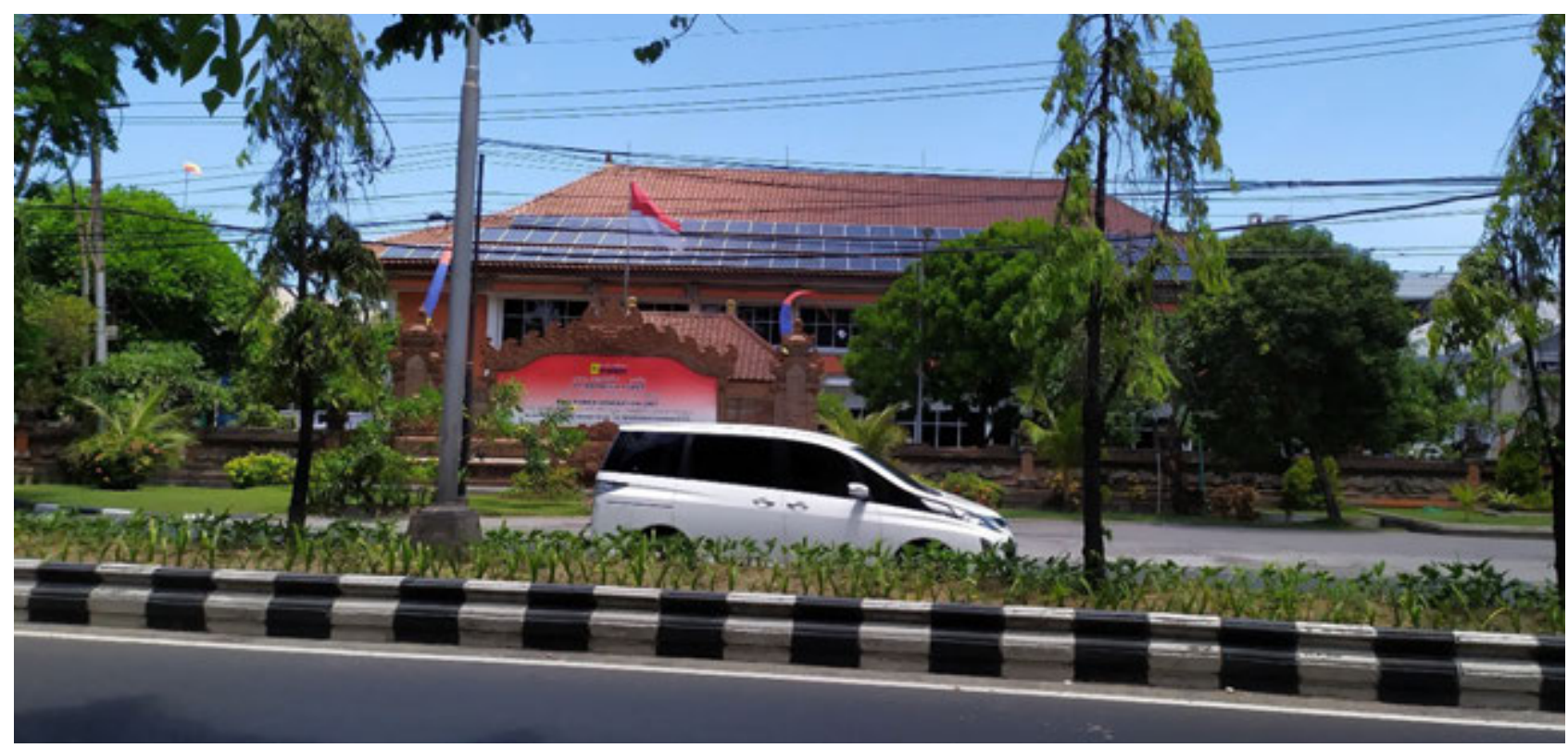

Gambar 24. PLTS Atap 24 kWp di Indonesia Power Pesanggaran 


\section{Industri pariwisata}

Industri pariwisata sangat erat kaitannya dengan penyediaan bangunan untuk akomodasi dan tempat makan serta hiburan. Bangunan-bangunan ini jumlahnya sangat besar karena industri pariwisata di Bali yang besar. Sektor pariwisata ini juga telah mulai mengembangkan PLTS Atap sebagai kontribusi sektor terhadap pembangunan PLTS dan juga sebagai bagian dari gerakan pariwisata hijau berkelanjutan yang dapat membantu meningkatkan daya saing dan citra perusahaan. Sebagai contoh, Waterbom Park di Kuta telah membangun PLTS Atap berkapasitas 156
kWp untuk mengurangi suplai energi listrik dari PLN. Prinsip model kerjasama ini disebut sebagai business to business (B2B) dimana Kontraktor PLTS bernama PT TGRA membangun PLTS Atap ini di atas bangunan milik Waterbom dan menjual energi listriknya ke Waterbom Park.

Selain itu, penggunaan atap surya juga sudah mulai dilakukan oleh beberapa hotel di Bali, seperti Hotel Mercure yang diperlihatkan pada Gambar 25 dan pada kawasan resort Long House yang diperlihatkan pada Gambar 26.

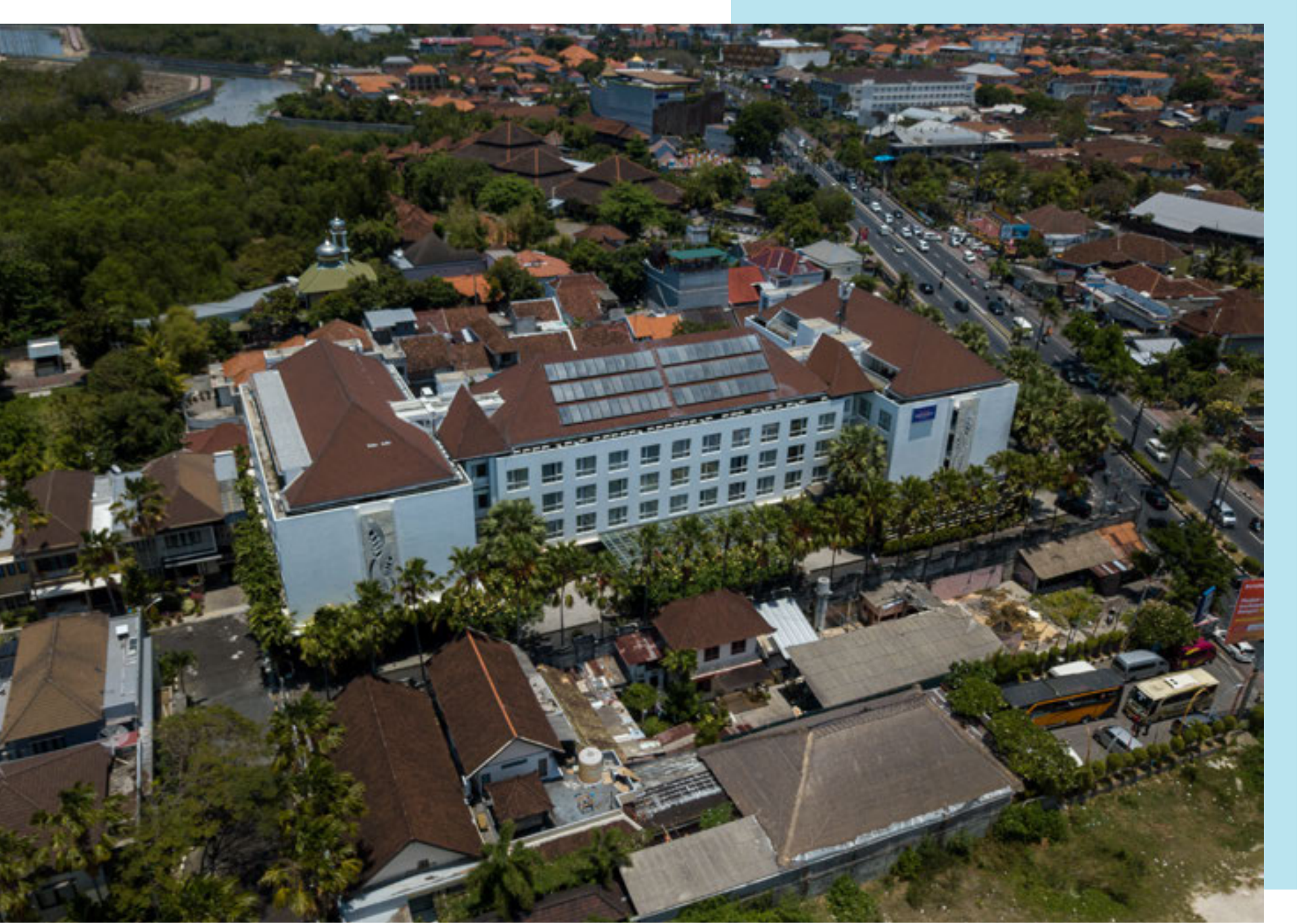

Gambar 25. PLTS Atap di Hotel Mercure Bali 


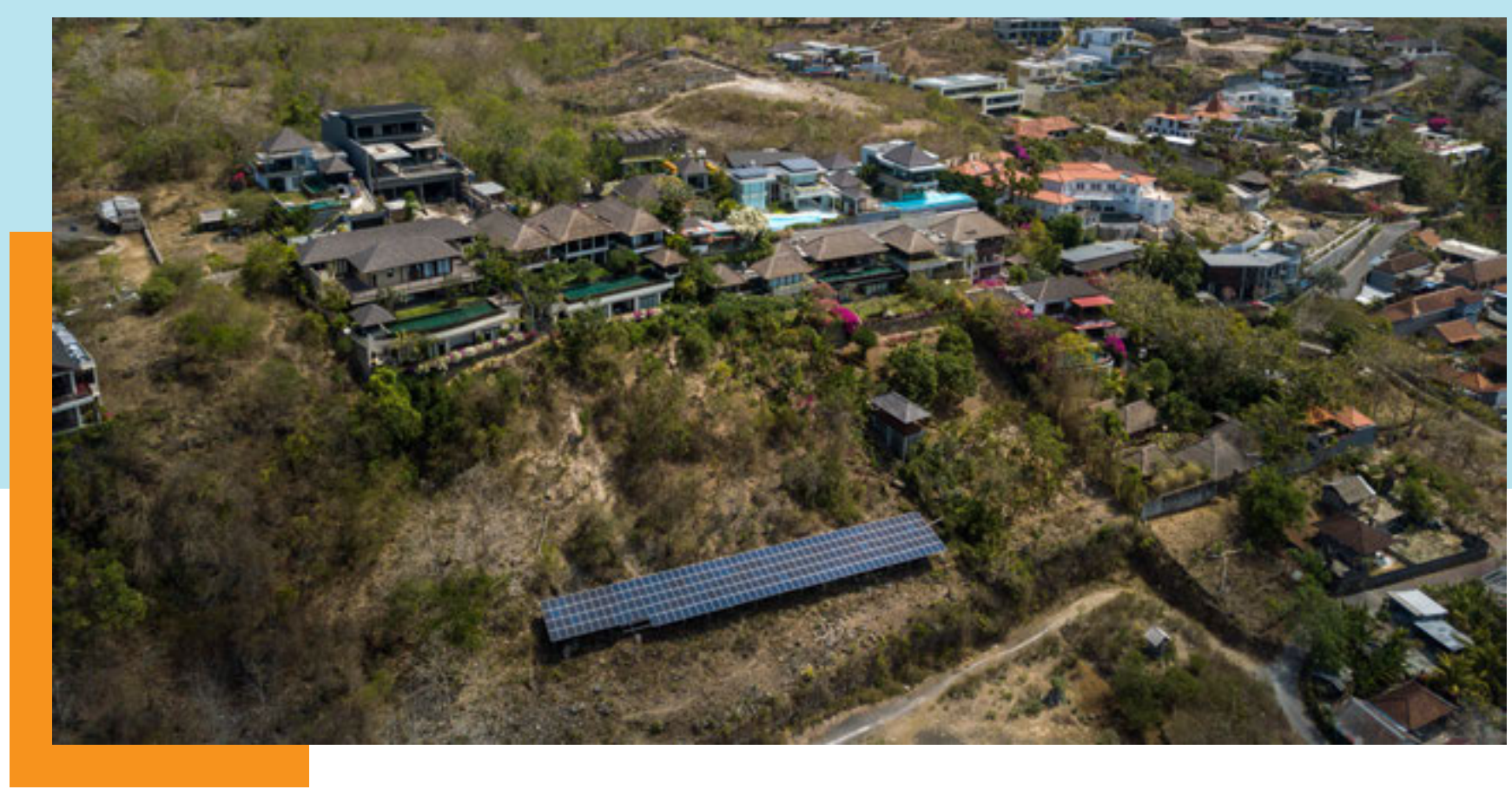

Gambar 26. PLTS Atap di kawasan resort The Longhouse Bali

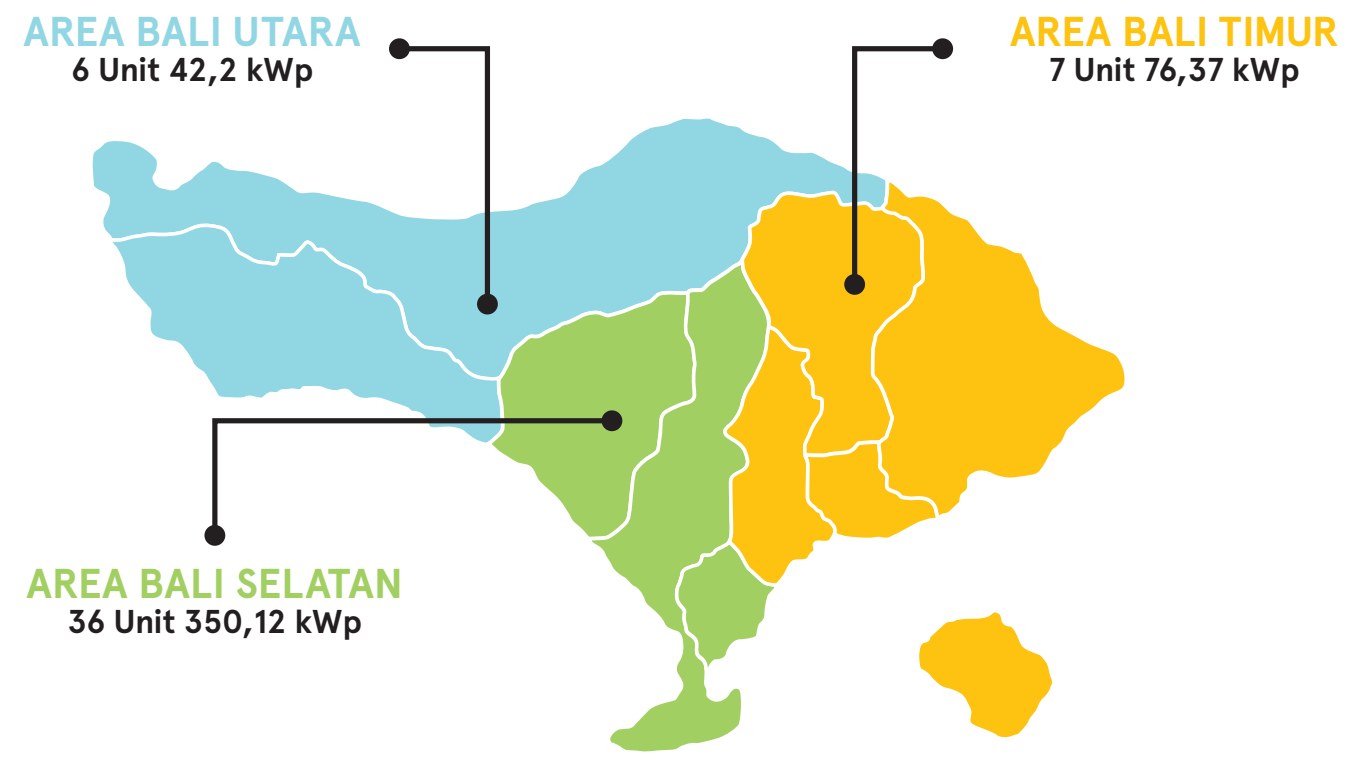

Gambar 27. Sebaran PLTS Atap di Bali

Berdasarkan data PLN UID Bali bahwa pemasangan PLTS Atap sudah mulai meningkat dan tersebar di seluruh Bali. Sampai pertengahan tahun 2019 jumlah PLTS Atap di Bali telah mencapai 49 unit dengan total kapasitas terpasang sekitar $470 \mathrm{kWp}$. Sebaran PLTS Atap di Bali diperlihatkan pada Gambar 27. PLTS Atap tersebar di Bali Selatan sebanyak 36 unit, Bali Timur 7 unit, dan Bali Utara 6 unit.
Dari data PLN ini semakin jelas bahwa PLTS Atap sudah berkembang di Bali khususnya di Bali Selatan dan potensinya sebagai komponen penting dalam upaya mencapai target kapasitas PLTS 108 MW tahun 2025. 


\section{Regulasi PLTS Atap}

Dari sisi aturan, pemasangan PLTS Atap sudah cukup jelas dengan adanya Permen ESDM No 49/2018 yang mengatur bahwa PLTS Atap terkoneksi grid bertujuan untuk mengurangi pasokan energi listrik dari PLN dengan membangkitkan tenaga listrik sendiri menggunakan PLTS Atap. Gambar 28 memperlihatkan skematik PLTS Atap menurut Permen ESDM tersebut.

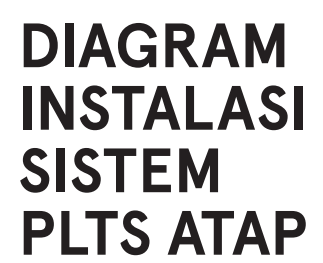

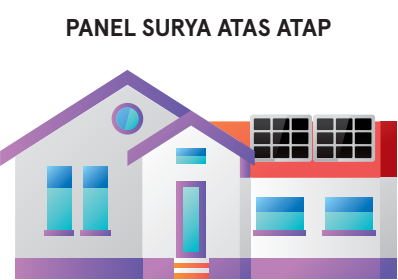

PEMUTUS DC
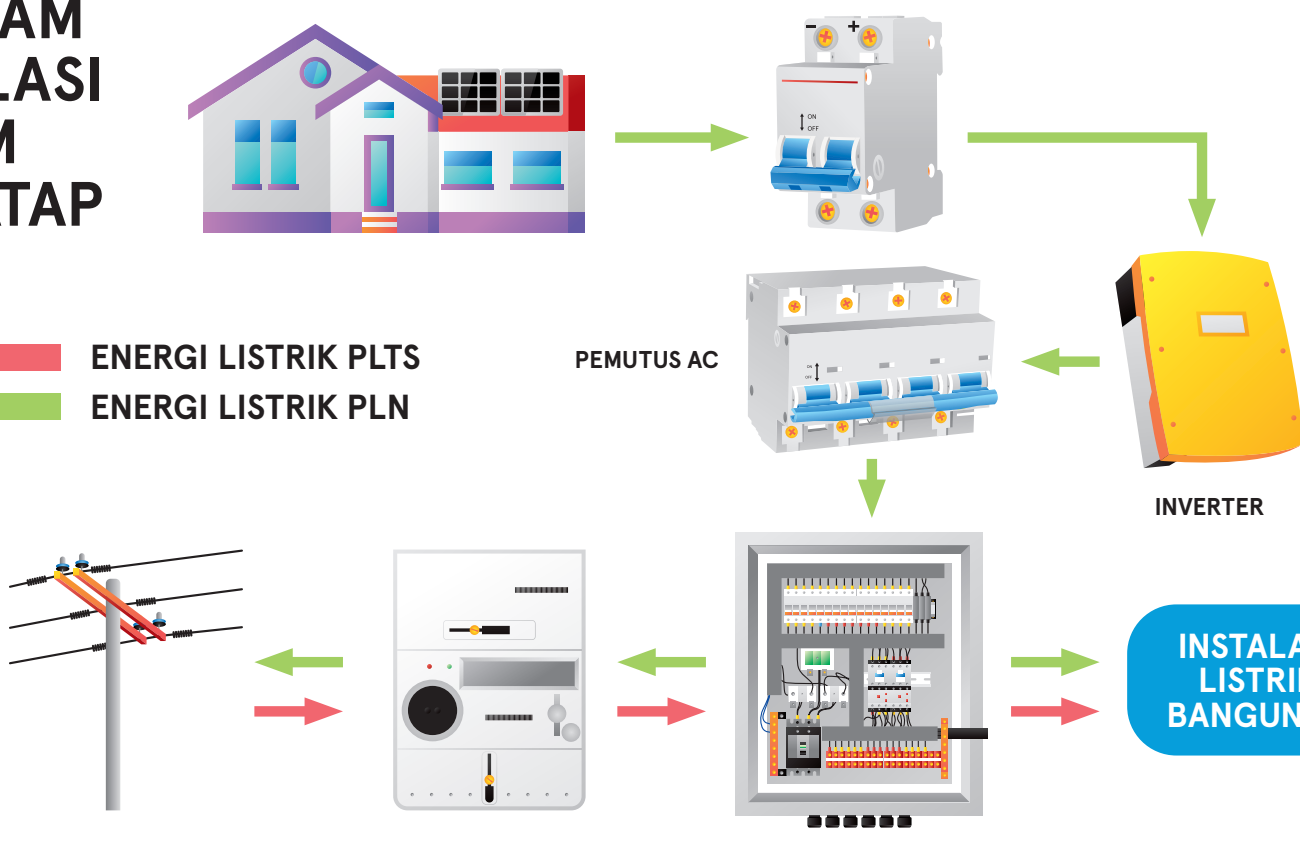

PANEL BAGI

PEMUTUS AC

\section{ENERGI LISTRIK PLTS ENERGI LISTRIK PLN}

Gambar 28. Skematik PLTS Atap sesuai Permen ESDM 49/2018

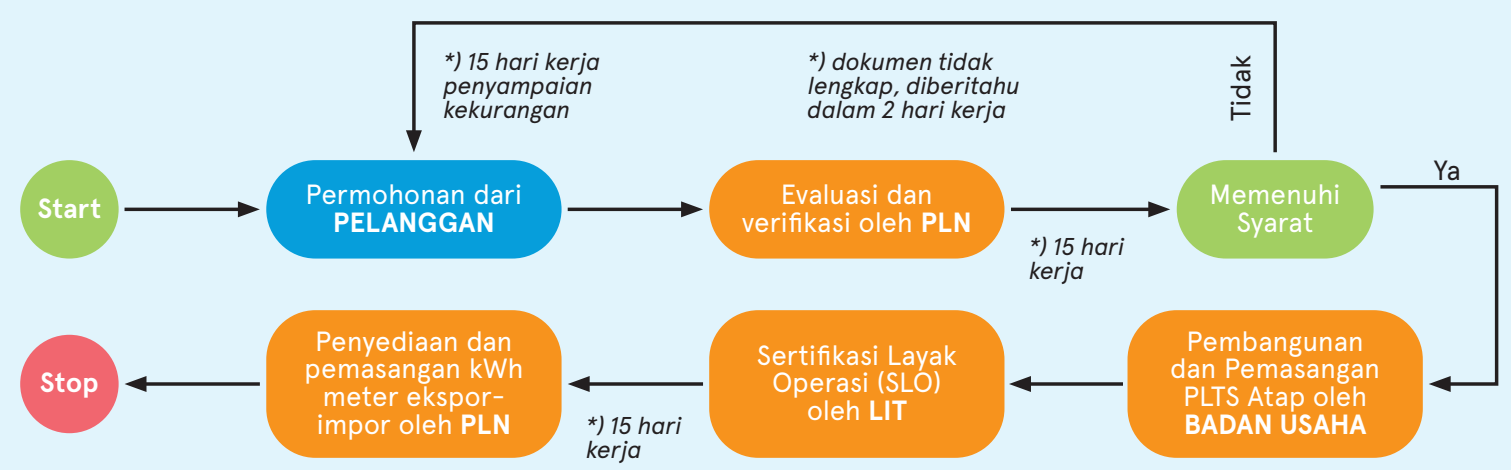

Gambar 29. Mekanisme pengajuan penyambungan PLTS Atap ke jaringan PLN 
Proses pengajuan permohonan oleh Pelanggan PLN untuk memasang PLTSAtap diperlihatkan pada Gambar 29. Dalam mengajukan permohonan penyambungan PLTS Atap, pelanggan harus menyertakan dokumen sebagai berikut: 1) surat permohonan, 2) single line diagram, 3) mencantumkan kapasitas PV, 4) menyertakan manual masing-masing peralatan yaitu inverter dan modul PV, 5) dokumen Sertifikat Laik Operasi, dan 6) surat pernyataan pelanggan.

\section{Kontraktor PLTS Di Bali}

Salah satu faktor penting dalam pembangunan PLTS Atap adalah adanya Badan Usaha atau perusahaan yang kompeten di bidang PLTS dan beroperasi atau berkantor di Bali. Keberadaan perusahaan di Bali akan meningkatkan keyakinan calon pemasang PLTS Atap tentang layanan purna jual. Melalui forum diskusi dan peninjauan on-line diperoleh bahwa ada beberapa perusahaan atau Kontraktor PLTS yang berkantor di Bali dan sudah berpengalaman dalam membangun PLTS Atap. Tabel 1 memperlihatkan Kontraktor PLTS yang berkantor dan beroperasi di Bali.

\begin{tabular}{l|l|c}
\multicolumn{1}{c|}{ Badan Usaha } & \multicolumn{1}{c}{ Alamat Kantor } & Tahun Berdiri \\
\hline PT Contained Energy Indonesia & Jl. Majapahit 55, Lingkungan Pemamoran, Kuta, Bali & 2004 \\
\hline PT Solar Power Indonesia & Jl. Siligita Blok I, No 1, Nusa Dua, Bali & 2007 \\
\hline Koperasi Amogasidhi & Jl. Noja No 143, Kesiman, Petilan, Denpasar Timur, Bali & 2016 \\
\hline Solar Energi Solusi & Jl. Gunung Agung No 86, Denpasar, Bali & 2017 \\
\hline Ineco Solar & Jl. Raya Canggu No 668, Br. Dinas Tandeng, Desa Tibubeneng, & 2018 \\
\hline PT Negeri Matahari Mandiri & Kuta Utara, Bali & 2019
\end{tabular}

Tabel 1. Badan Usaha yang bergerak dalam pemasangan PLTS Atap di Bali

Sementara di tingkat nasional, berdasarkan tinjauan terhadap sistem pen-tender-an on-line di Kementerian ESDM untuk proyek-proyek terkait PLTS di seluruh Indonesia, terdapat hampir 300 Badan Usaha yang ikut mengajukan penawaran. Sebagian besar Badan Usaha ini berada di Jawa Barat dan
Jakarta atau masih terpusat di Jawa bagian barat. Namun demikian, keberadaan Badan Usaha yang sudah kompeten dan dalam jumlah yang cukup menunjukkan kesiapan Badan Usaha dalam merespon proyek PLTS di Indonesia. 


\section{Investasi PLTS Atap}

Membangun PLTS Atap merupakan sebuah investasi yang cukup besar. Berdasarkan survei yang dilakukan terhadap sejumlah Kontraktor PLTS atau EPC yang berada di Bali harga sebuah PLTS Atap tergantung dari kapasitas daya yang dibangun, lokasi pemasangan, serta kondisi atap.

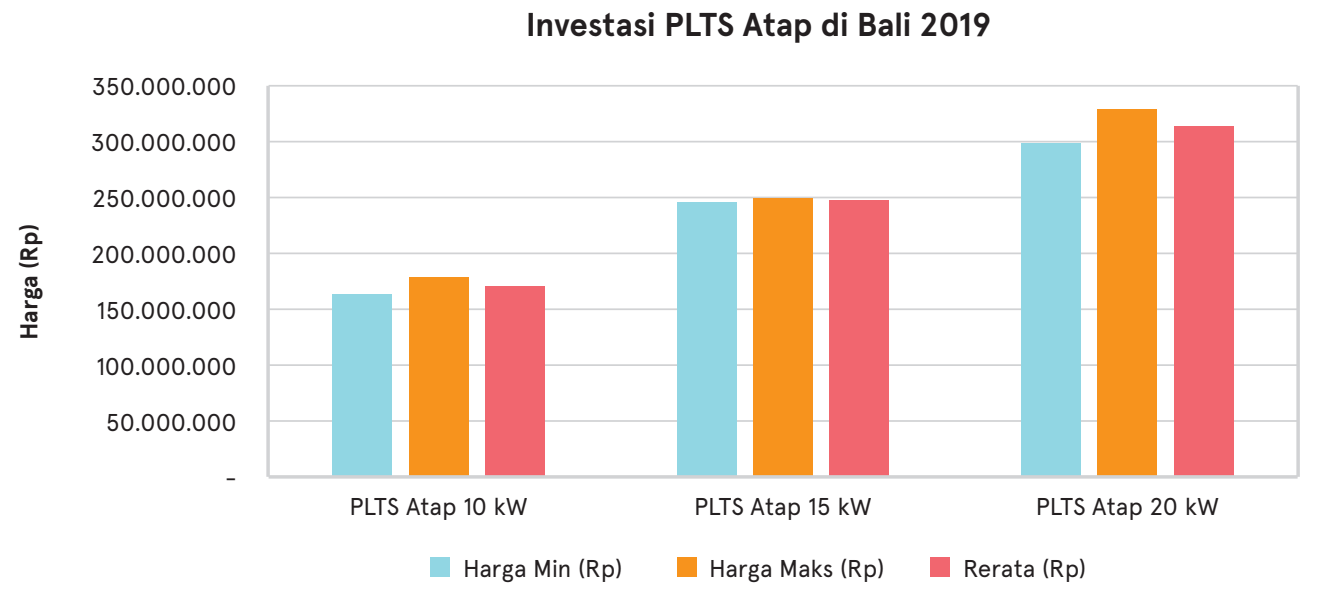

Gambar 30. Kisaran harga PLTS Atap di Bali tahun 2019

\begin{tabular}{|l|r|r|r|r|}
\hline Kapasitas PLTS & Harga Min (Rp) & Harga Maks (Rp) & Rerata (Rp) & Rerata per kWp (Rp) \\
\hline PLTS Atap 10 kW & 165.000 .000 & 180.000 .000 & 171.666 .667 & 17.166 .667 \\
\hline PLTS Atap 15 kW & 247.000 .000 & 250.000 .000 & 249.166 .667 & 16.611 .111 \\
\hline PLTS Atap 20 kW & 300.000 .000 & 330.000 .000 & 315.000 .000 & 15.750 .000 \\
\hline
\end{tabular}

Tabel 2. Harga PLTS Atap berbagai kapasitas

\section{Simulasi Energi PLTS Atap}

Untuk mengetahui besarnya energi yang bisa dihasilkan oleh PLTS Atap maka dilakukan simulasi menggunakan Helioscope untuk PLTS Atap berkapasitas 10, 15, dan 20 kWp. Simulasi PLTS Atap ini dilakukan pada dua lokasi yang memiliki kondisi iklim dan cuaca yang sangat berbeda. Lokasi pertama adalah di pusat pemerintahan Kabupaten Bangli dan lokasi kedua adalah di pusat pemerintahan Kabupaten Karangasem.
Kabupaten Bangli memiliki iklim basah dengan suhu harian yang relatif sejuk sementara Kabupaten Karangasem adalah daerah yang beriklim kering, suhu tinggi, dan curah hujan yang minimal. Gambar 31, Gambar 32, dan Gambar 33 memperlihatkan estimasi produksi energi per bulan selama setahun dari PLTS Atap $10 \mathrm{kWp}, 15 \mathrm{kWp}$, dan $20 \mathrm{kWp}$. Dapat dilihat bahwa produksi energi di kedua lokasi yang cukup ekstrim tersebut produksi energinya tidak berbeda terlalu besar. 


\section{Produksi Energi PLTS Atap $10 \mathrm{kWp}$}

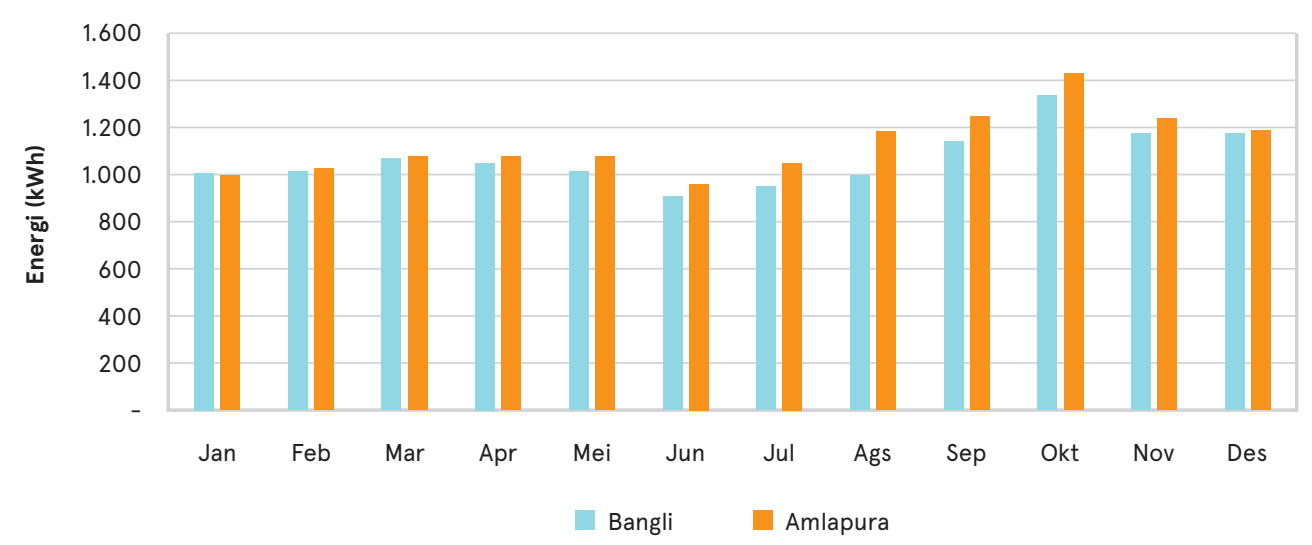

Gambar 31. Simulasi produksi energi PLTS Atap $10 \mathrm{kWp}$

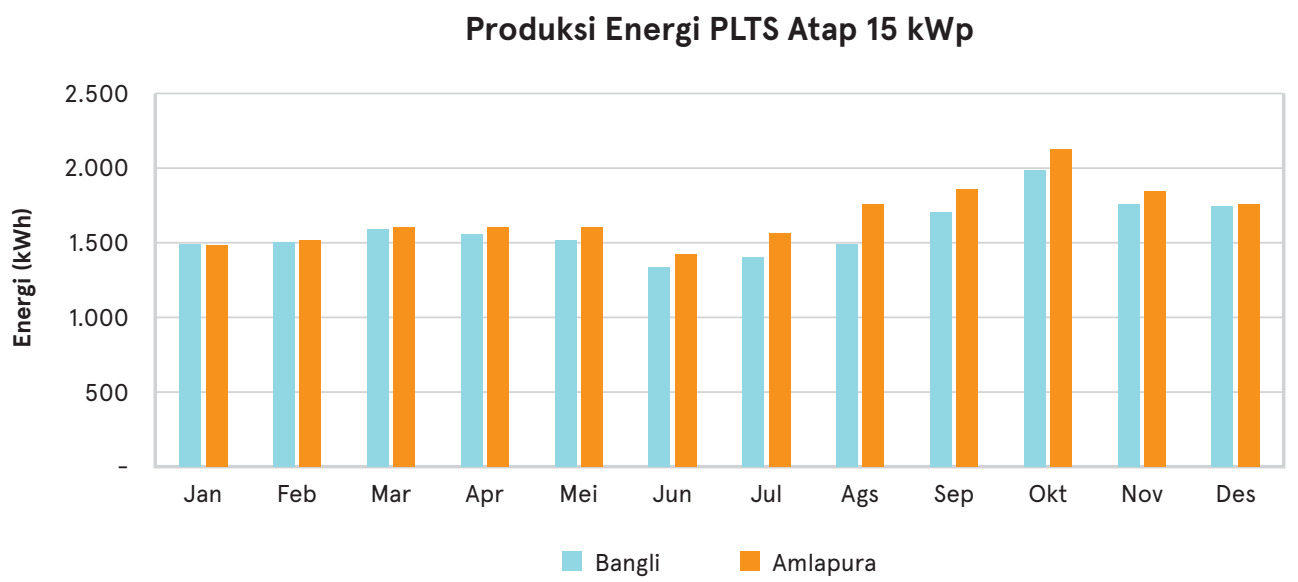

Gambar 32. Simulasi produksi energi PLTS Atap $15 \mathrm{kWp}$

\section{Produksi Energi PLTS Atap 20 kWp}

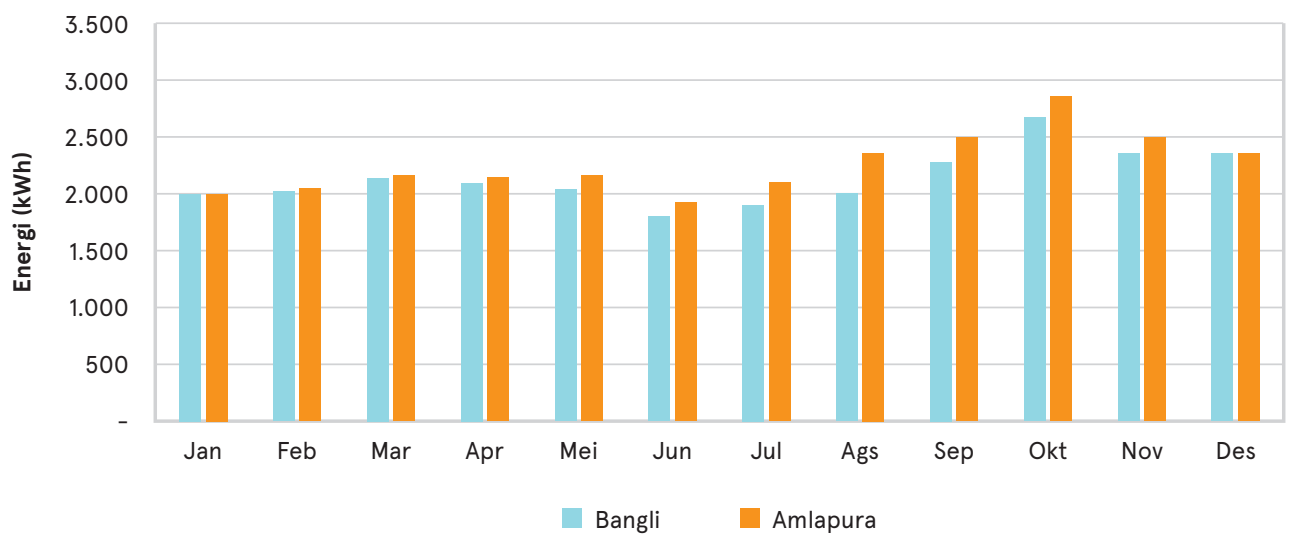

Gambar 33. Simulasi produksi energi PLTS Atap 20 kWp 


\section{8.}

\section{Potensi PLTS Atap di Bali}

Berdasarkan tinjauan terhadap indikator demografi, ekonomi, dan energi yang telah dipaparkan sebelumnya maka pengkajian potensi PLTS Atap bangunan di Bali akan difokuskan di wilayah Bali Selatan. Wilayah Bali Selatan ditunjukkan pada Gambar 34 terdiri dari Kota Denpasar, Kabupaten Badung, Kabupaten Gianyar, dan Kabupaten Tabanan.

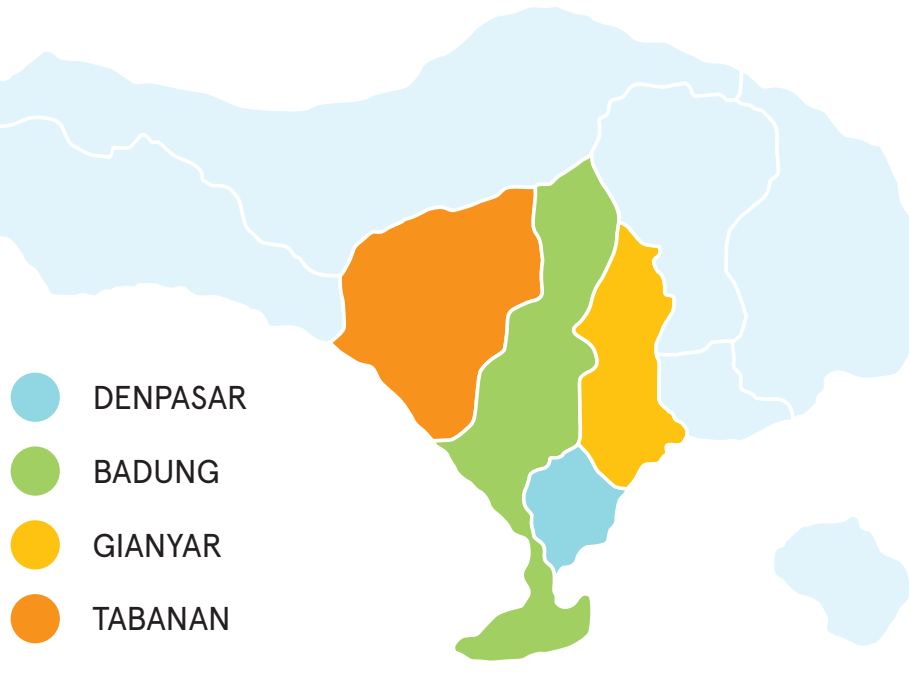

Gambar 34. Wilayah Bali Selatan atau SARBAGITA sebagai fokus kajian

Dalam kajian potensi atap ini dibatasi pada pemangku kepentingan PLTS Bali yang terdiri dari: 1) PLN UID Bali yang berwenang dalam mendistribusikan tenaga listrik di Bali, 2) Pemerintah Bali dan Pemerintah SARBAGITA, 3) Perguruan Tinggi di Bali, 4) ITDC Nusa Dua, dan 5) Desa Adat. Dalam menghitung potensi PLTS Atap kapasitas akan dihitung dengan asumsi pemanfaatan luas atap sebesar $25 \%-60 \%$ dari luas total atap bangunan. 


\section{PT PLN UID Bali}

PT PLN (Persero) Unit Induk Distribusi (UID) Bali membagi Bali menjadi 3 wilayah kerja yang disebut Unit Pelaksana Pelayanan Pelanggan (UP3), yaitu UP3 Bali Selatan, UP3 Bali Timur, dan UP3 Bali Utara serta Unit Pelaksana Pengatur Distribusi (UP2D) Bali. Wilayah kerja dari setiap UP3 ditunjukkan pada Gambar 35. Setiap UP3 juga memiliki Unit Layanan
Pelayanan (ULP). Jumlah ULP di seluruh Bali adalah sebanyak 14 unit.

Total luas atap dari bangunan yang dimiliki oleh PLN Unit Induk Bali adalah sebesar 26.135 meter persegi. Potensi PLTS Atap dari seluruh bangunan PLN UID Bali berkisar dari $6.534-8.476 \mathrm{kWp}$.

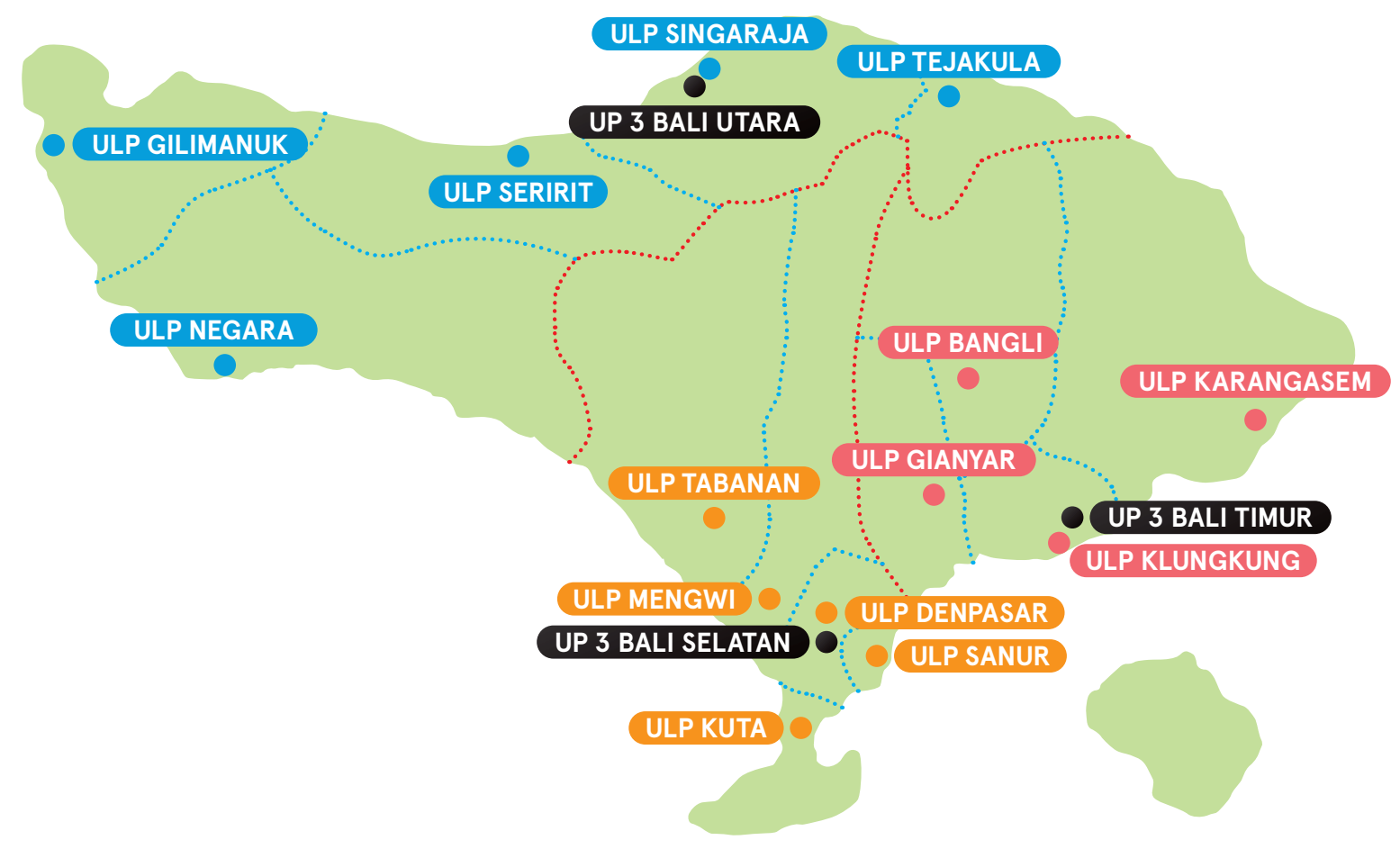

Gambar 35. Kantor PLN Bali tersebar di seluruh Bali

\section{Pemerintah Provinsi Bali dan SARBAGITA}

Pemerintah Provinsi Bali dan SARBAGITA memiliki bangunan beratap yang bisa dimanfaatkan untuk PLTS Atap. Luas total atap bangunan milik Pemerintah Bali adalah sekitar 54.364 meter persegi. Potensi PLTS
Atap bangunan tersebut berkisar antara 2.387 $3.383 \mathrm{kWp}$. Gambar 36 memperlihatkan foto udara Kantor Gubernur Bali dimana PLTS Atap di pasang di atas lapangan tenis. 


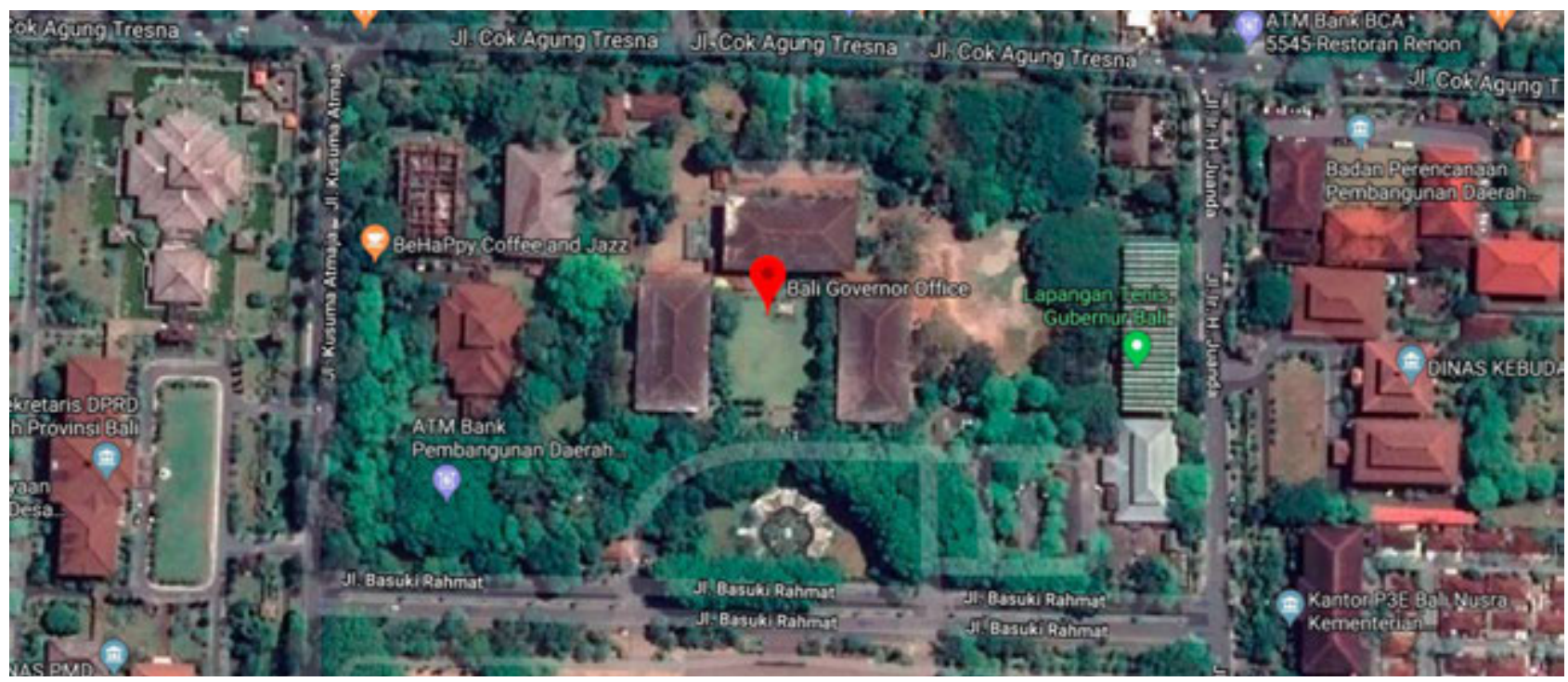

Gambar 36. Foto udara Kantor Gubernur Bali

Luas total atap bangunan milik Pemerintah Kota Denpasar adalah 44.593 meter persegi. Potensi PLTS Atap berkisar antara 1.958 - 5.134 kWp. Foto udara kompleks kantor layanan Pemerintah Kota Denpasar diperlihatkan pada Gambar 37.

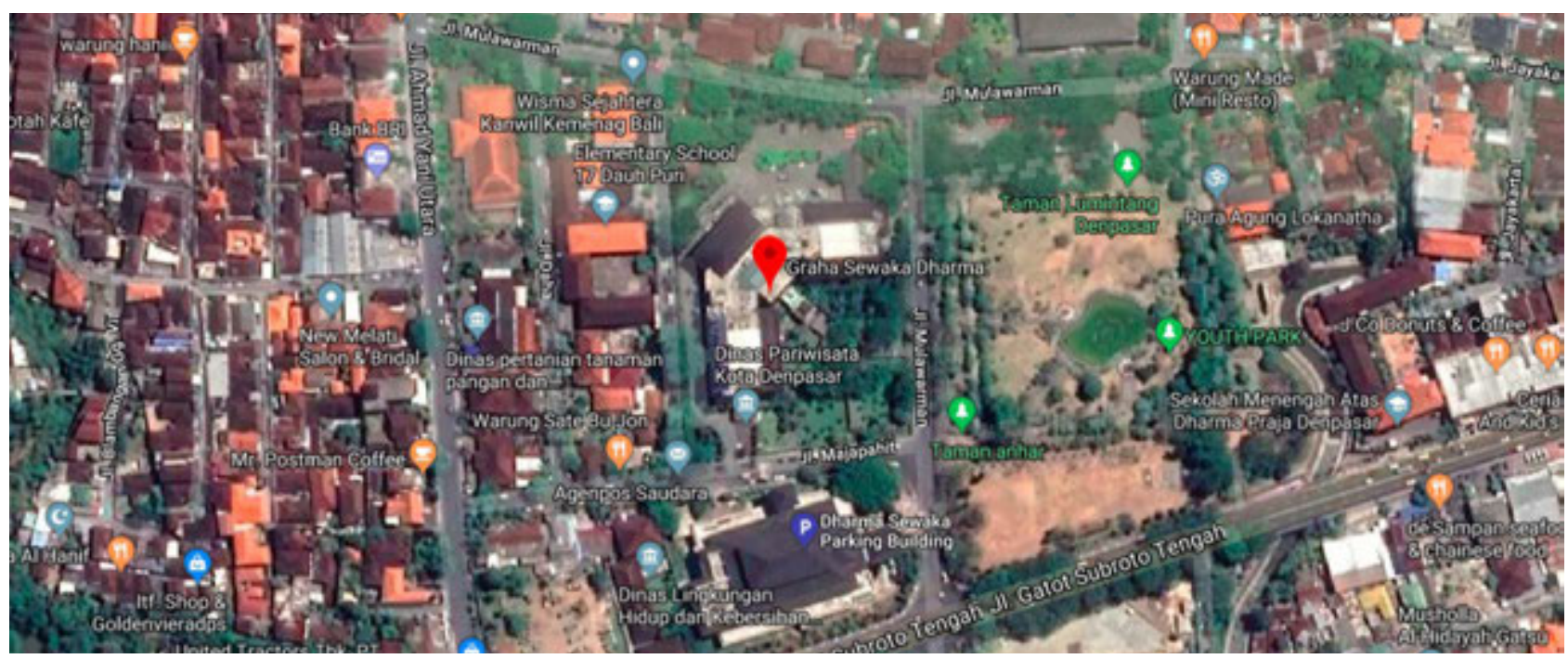

Gambar 37. Komplek Gedung Sewaka Dharma milik Pemerintah Kota Denpasar

Total atap bangunan milik Pemerintah Kabupaten Badung adalah 54.566 meter persegi. Potensi PLTS Atap dari bangunan-bangunan tersebut berkisar antara $2.396 \quad$ - 6.282 kWp. Kompleks Pusat Pemerintahan Kabupaten Badung diperlihatkan pada Gambar 38. 


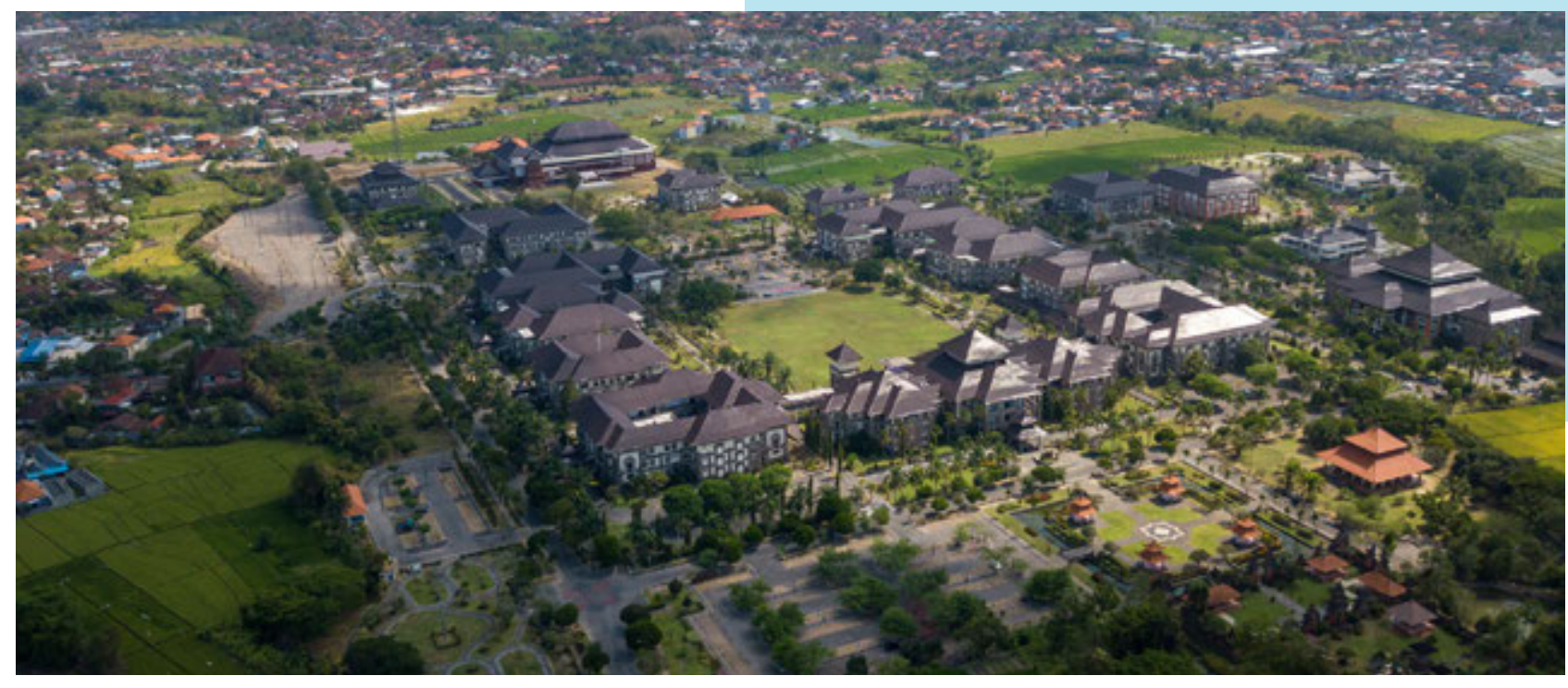

Gambar 38. Pusat Pemerintahan Kabupaten Badung

Total luas atap bangunan milik Pemerintah Kabupaten Gianyar adalah sekitar 11.656 meter persegi. Potensi PLTS Atap dari bangunan-bangunan tersebut berkisar antara 511 - 1.342 kWp. Foto udara dari komplek Kantor Pemerintah Kabupaten Gianyar diperlihatkan pada Gambar 39.

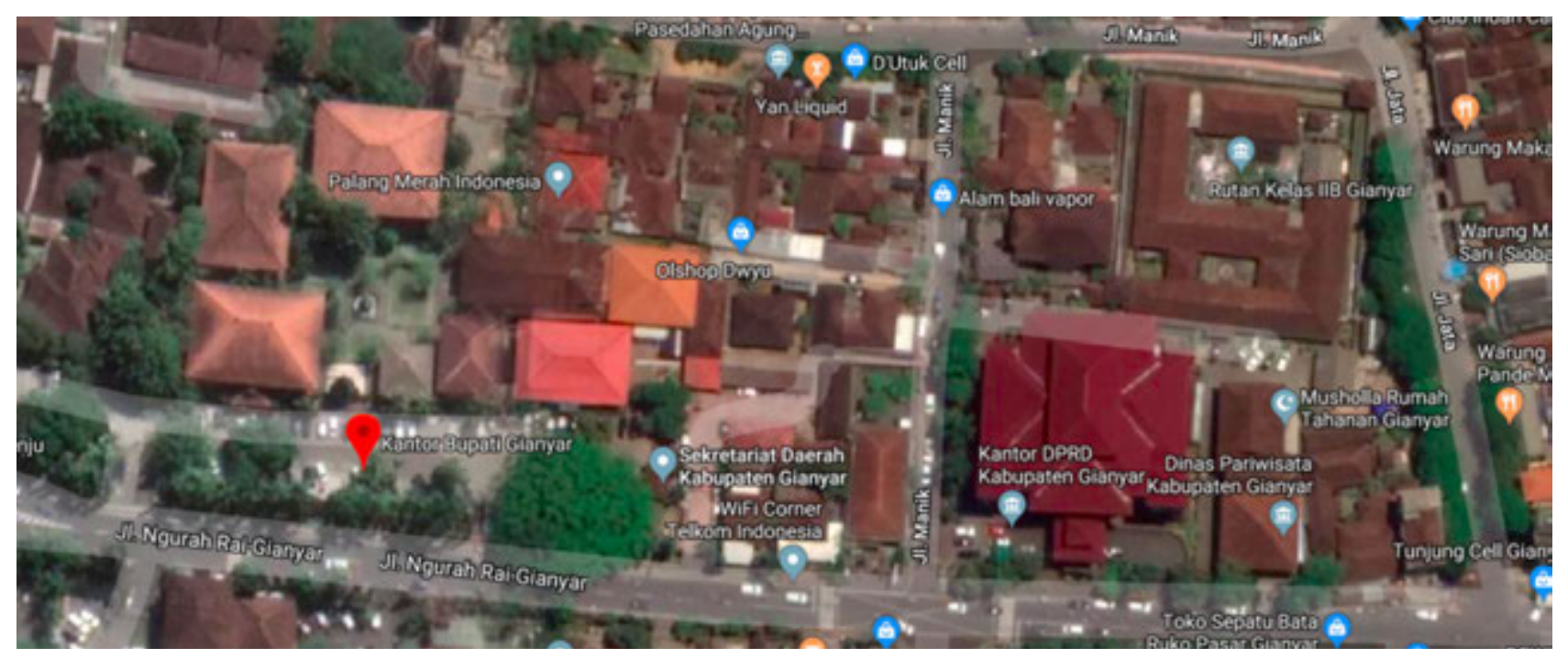

Gambar 39. Pusat pemerintahan Kabupaten Gianyar

Total luas atap bangunan milik Pemerintah Kabupaten Tabanan adalah 72.568 meter persegi. Potensi PLTS Atap dari bangunan-bangunan tersebut berkisar antara 3.187 - 8.355 kWp. Gambar 40 memperlihatkan komplek perkantoran Pemerintah Kabupaten Tabanan. 


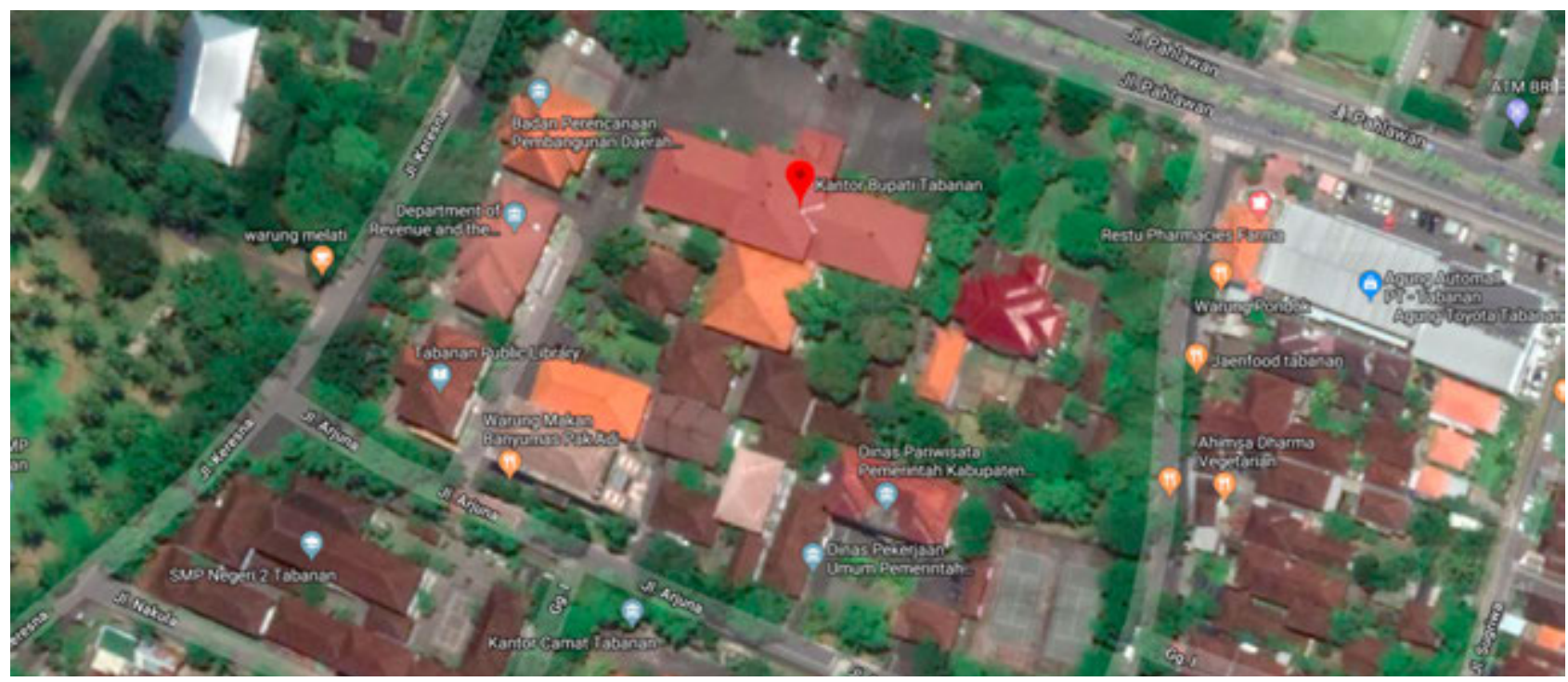

Gambar 40. Pusat Pemerintahan Kabupaten Tabanan

Berdasarkan data luas atap bangunan di atas maka total keseluruhan atap bangunan milik Pemerintah Provinsi Bali dan Pemerintah SARBAGITA adalah sekitar sekitar 237.748 meter persegi. Potensi pemanfaatan PLTS Atap dari bangunan tersebut berkisar antara $10.441-27.373 \mathrm{kWp}$.

\section{Perguruan Tinggi di Bali}

Di Bali terdapat 51 buah lembaga pendidikan tinggi seperti perguruan tinggi, politeknik, institut, akademi, dan sekolah tinggi baik yang negeri maupun swasta. Lembaga pendidikan tinggi ini memiliki banyak bangunan yang atapnya bisa dimanfaatkan untuk PLTS Atap. Luas seluruh atap bangunan PTN atau PTS di Bali adalah sekitar 214.198 meter persegi. Potensi PLTS Atap dari bangunan-bangunan tersebut berkisar antara 9.407 - 24.661 kWp. Gambar 41 memperlihatkan salah satu Kampus Universitas Udayana di Jalan Sudirman Denpasar.

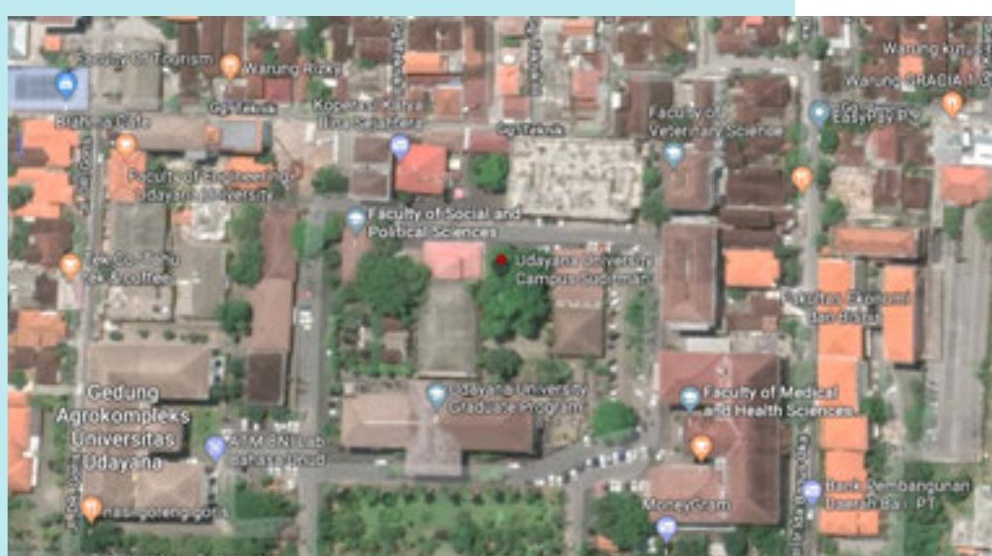

Gambar 41. Kampus Universitas Udayana di Denpasar 


\section{ITDC Nusa Dua}

Indonesia Tourist Development Corporation mengelola kawasan wisata Nusa Dua. Di dalam kawasan ITDC terdapat 19 hotel dan villa, 2 fasilitas untuk Meeting, Incentive, Convention, and Exhibition (MICE), 16 fasilitas lainnya seperti museum, restoran, fasilitas kesehatan, dll. Total seluruh atap bangunan di kawasan ITDC adalah sekitar 403.586 meter persegi. Potensi PLTS Atap dari bangunan di kawasan ITDC berkisar antara 17.725 - 46.466 kWp. Gambar 42 memperlihatkan kawasan Nusa Dua yang dikelola oleh ITDC Bali.

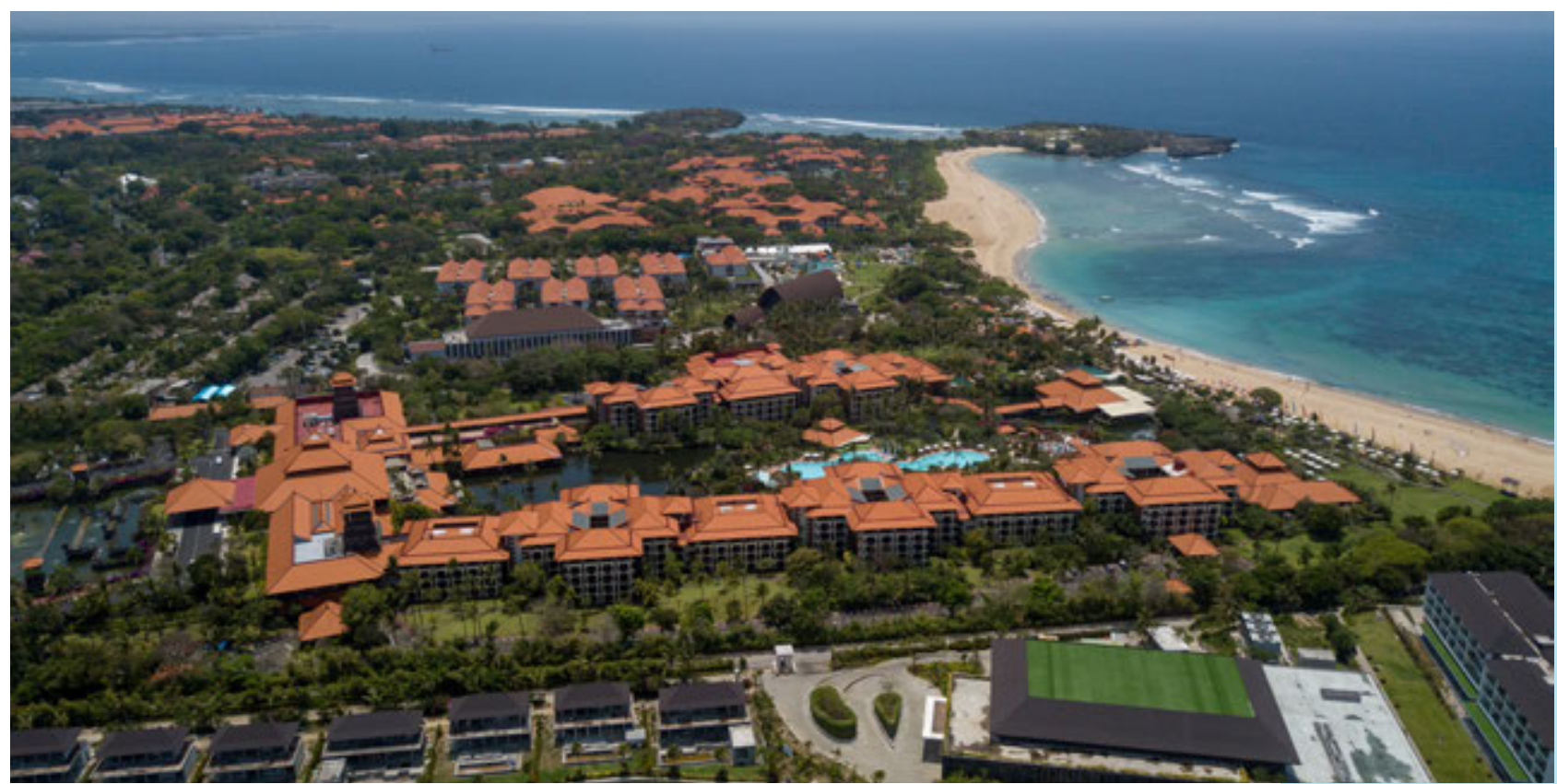

Gambar 42. Foto udara kawasan wisata ITDC Nusa Dua

\section{Potensi Desa Adat Bali}

Desa Adat menurut Peraturan Daerah Bali No 4 Tahun 2019 adalah kesatuan masyarakat hukum adat di Bali yang memiliki wilayah, kedudukan, susunan asli, hakhak tradisional, harta kekayaan sendiri, tradisi, tata krama pergaulan hidup masyarakat secara turun temurun dalam ikatan tempat suci (kahyangan tiga atau kahyangan desa), tugas dan dan kewenangan serta hak mengatur dan mengurus rumah tangganya sendiri. Desa Adat dalam wilayahnya memiliki berbagai aset termasuk bangunan gedung misalnya balai banjar atau wantilan. Setiap Desa Adat di Bali memiliki paling tidak satu balai banjar yang digunakan sebagai tempat untuk melakukan kegiatan bersama atau kegiatan pertemuan. 


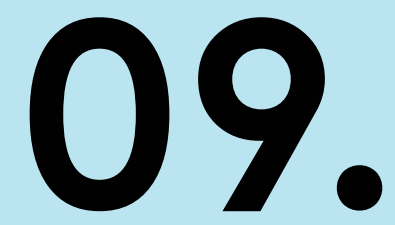

\section{Rekomendasi Pengembangan PLTS Atap Bali}

\section{Kapasitas PLTS Atap}

Potensi atap bangunan pemangku kepentingan di wilayah SARBAGITA dan PLN Bali adalah sekitar 1.127.187 meter persegi. Dengan teknologi PLTS Atap saat ini akan diperoleh kapasitas daya berkisar antara 49.504 - $129.778 \mathrm{kWp}$ melalui skenario pemanfaatan luas atap antara $25 \%-60 \%$. Angka ini menunjukkan bahwa Bali memiliki potensi yang besar untuk memenuhi target PLTS 108 MW pada tahun 2025. Di samping itu, angka ini baru mengambil sebagian dari komponen masyarakat Bali sementara rumah tangga yang jumlahnya sangat besar dan pemangku kepentingan di luar wilayah SARBAGITA juga memiliki potensi yang besar belum diperhitungkan dalam kajian ini.

Pendekatan yang diusulkan untuk mencapai target 108 MW pada tahun 2025 dalam kajian ini adalah dengan membagi target kapasitas ini secara merata selama periode 2020 - 2025. Dengan pendekatan ini, maka setiap tahun Bali harus membangun PLTS dengan kapasitas total 18 MW. Terkait pencapaian target tersebut, sektor pariwisata dan PLN sangat dimungkinkan untuk didorong lebih progresif dalam membangun PLTS Atap yang selanjutnya dapat diikuti oleh komponen masyarakat yang lain. Target tahunan dan akumulasi PLTS Bali menuju kapasitas 108 MW pada tahun 2025 ditunjukkan pada Gambar 44. 
Target Tahunan dan Akumulatif PLTS Bali 2020-2025

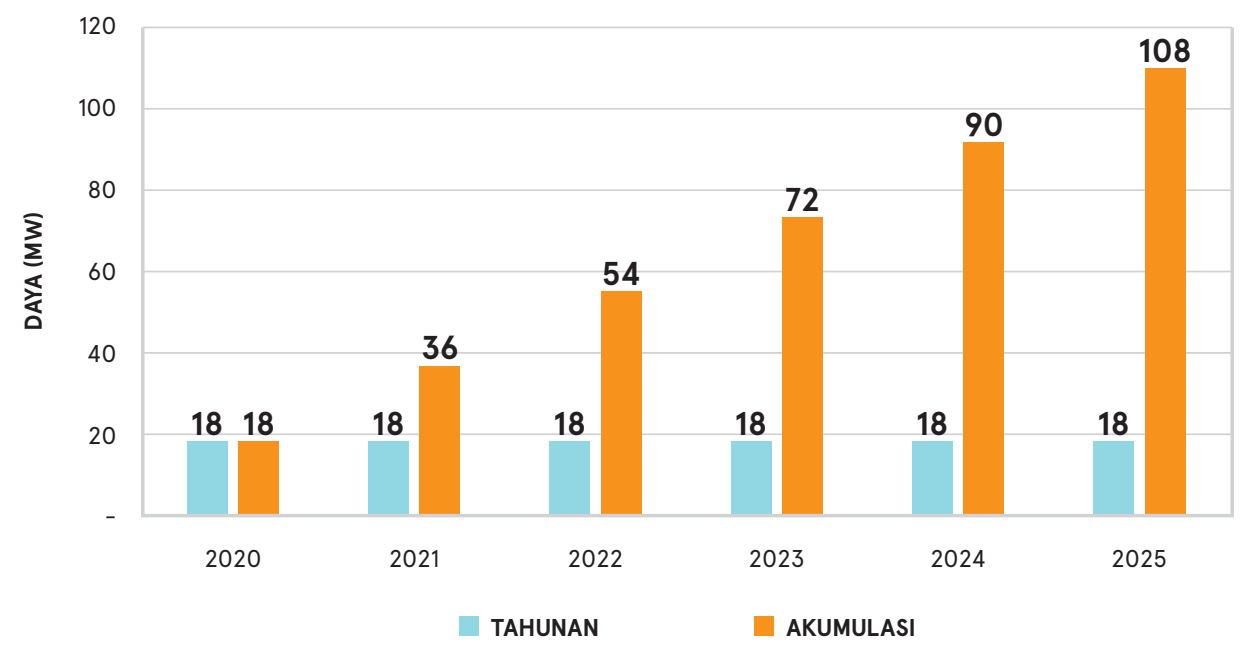

Gambar 44. Rencana Perkembangan PLTS di Bali 2020 - 2025

Tahapan kegiatan dari pemangku kepentingan dalam mendukung pencapaian target PLTS Bali ditunjukkan pada matrik kegiatan pemangku kepentingan [Gambar 45].

\begin{tabular}{|c|c|c|c|c|c|c|c|}
\hline Komponen Masyarakat & 2020 & 2021 & 2022 & 2023 & 2024 & 2025 & $2026-2050$ \\
\hline Pemerintah Propinsi Bali & \multicolumn{7}{|c|}{ Kebijakan/ Regulasi/ Monitoring/ Awarding } \\
\hline Pemerintah SARBAGITA & Sosialisasi & Penganggaran & \multicolumn{4}{|c|}{ PLTS Atap (APBD/ ESCO/Inovatif) } & $\begin{array}{l}\text { PLTS Atap } \\
\text { Inovatif }\end{array}$ \\
\hline PT PLN UID Bali & \multicolumn{6}{|c|}{ Progresif + Model Inovatif } & $\begin{array}{l}\text { PLTS Atap } \\
\text { Inovatif }\end{array}$ \\
\hline $\begin{array}{l}\text { ITDC Nusa Dua dan Sektor } \\
\text { Pariwisata }\end{array}$ & \multicolumn{6}{|c|}{ Progresif + Model Inovatif } & $\begin{array}{l}\text { PLTS Atap } \\
\text { Inovatif }\end{array}$ \\
\hline Perguruan Tinggi & Sosialisasi & Riset/ Pilot & \multicolumn{4}{|c|}{ PLTS Atap + Pembiayaan Inovatif } & $\begin{array}{l}\text { PLTS Atap } \\
\text { Inovatif }\end{array}$ \\
\hline Desa Adat di SARBAGITA & Sosialisasi & Pendampingan & \multicolumn{4}{|c|}{ PLTS Atap (Dana Desa/ LPD/ Koperasi) } & $\begin{array}{l}\text { PLTS Atap } \\
\text { Inovatif }\end{array}$ \\
\hline Pemerintah 4 Kabupaten & & & & & Sosialisasi & Penganggaran & $\begin{array}{l}\text { PLTS Atap } \\
\text { Inovatif }\end{array}$ \\
\hline Rumah Tangga seluruh Bali & & & & & \multicolumn{2}{|c|}{ Sosialisasi } & $\begin{array}{l}\text { PLTS Atap } \\
\text { Inovatif }\end{array}$ \\
\hline $\begin{array}{l}\text { Industri/ Bisnis di luar } \\
\text { Sektor Pariwisata }\end{array}$ & & & & & \multicolumn{2}{|c|}{ Sosialisasi } & $\begin{array}{l}\text { PLTS Atap } \\
\text { Inovatif }\end{array}$ \\
\hline Desa Adat di 4 Kabupaten & & & & & \multicolumn{2}{|c|}{ Sosialisasi } & $\begin{array}{l}\text { PLTS Atap } \\
\text { Inovatif }\end{array}$ \\
\hline $\begin{array}{l}\text { Investor PLTS ground mount } \\
\text { skala besar }\end{array}$ & \multicolumn{7}{|c|}{ Buleleng, Karangasem, Nusa Penida } \\
\hline
\end{tabular}


PLTS Atap inovatif yang dimaksud dalam Gambar 46 adalah PLTS Atap yang model pembiayaan atau pengelolaannya bersifat fleksibel mengikuti regulasi dan perkembangan pasar. Beberapa model yang mungkin bisa diterapkan antara lain, sebagai berikut:

1. Model dimana PLN memasang PLTS Atap di atap bangunan milik Pelanggan dan bertanggungjawab terhadap operasional sistem PLTS. Pelanggan menanggung investasi PLTS.

2. Model dimana PLN memberikan solusi total dengan memasang PLTS Atap dan memeliharanya dan Pelanggan cukup membayar tagihan listrik seperti biasa namun dengan tarif khusus. Tarif khusus adalah tarif energi listrik PLTS yang ditentukan oleh Pemerintah dan/atau PLN.

3. Model dimana Pelanggan bisa bekerjasama dengan Badan Usaha untuk memasang PLTS Atap di tempat Pelanggan. Pembiayaan dan pengelolaan PLTS Atap ditetapkan berdasarkan perjanjian kedua belah pihak.

4. Model dimana Pelanggan bisa bekerjasama dengan lembaga seperti ESCO untuk memasang atau mengelola PLTS Atap di tempat Pelanggan.

5. Atau model atau skema inovatif lain yang pada prinsipnya memberikan keuntungan kepada pihak-pihak yang bekerjasama.

\section{Kebijakan dan Regulasi}

Pemerintah Provinsi Bali memiliki peran yang sangat penting dalam menentukan strategi untuk mencapai target PLTS yang telah ditetapkan oleh Pemerintah Pusat dalam RUEN. Pemerintah Bali yang memiliki banyak aset bangunan dapat memanfaatkan sumber daya ini untuk mempercepat tercapainya target RUEN 108 MW pada tahun 2025. Di samping itu, Pemerintah Bali dapat menggunakan wewenangnya untuk menetapkan arah, kebijakan, dan regulasi terkait PLTS Atap di wilayah Provinsi Bali agar pemangku kepentingan dan masyarakat dapat ikut berkontribusi untuk mencapai target tersebut. Salah satu bentuk regulasi yang efektif adalah memasukkan PLTS Atap sebagai bagian dari persyaratan permohonan Izin Mendirikan Bangunan (IMB) yang dikeluarkan oleh Pemerintah Kabupaten/ Kota khususnya untuk pendirian komplek perumahan, rumah mewah, serta bangunan komersial atau industri.

Di negara-negara yang kontribusi PLTS dalam bauran pembangkitan tenaga listriknya sudah besar misalnya Cina, Jepang, Amerika, Jerman, India, Italia, Inggris, Australia, Perancis, dan Korea Selatan dicapai melalui pemberian berbagai insentif pajak dan finansial bagi masyarakat yang memasang PLTS. Salah satu contoh kebijakan yang diterapkan oleh pemerintah negara- negara tersebut adalah feed-in-tariff (FIT), yaitu kebijakan pemerintah dengan menerapkan harga beli energi listrik PLTS Atap lebih tinggi dari harga energi listrik yang dibayar konsumen ke perusahaan penyedia tenaga listrik. Hal ini telah mendorong perkembangan PLTS Atap yang sangat besar dan dalam waktu yang singkat. Namun kebijakan FIT ini berangsur-angsur dihentikan karena tujuan awalnya untuk mempercepat perkembangan kapasitas terpasang sudah berhasil dicapai.

Di samping kebijakan FIT itu, pemerintah negaranegara maju tersebut juga memberikan subsidi langsung pada investasi awal pembangunan PLTS Atap. Sebagai contoh, pemerintah Cina melalui Golden Sun Demonstration Program, memberikan subsidi sebesar \$2.4/W dari investasi PLTS Atap yang dipasang masyarakat. Melalui skema ini, pemerintah Cina memberikan 50\% dukungan modal untuk PLTS on-grid dan $70 \%$ untuk PLTS off-grid. Sehingga pada Maret 2016, Cina telah berhasil membangun PLTS dengan total kapasitas terpasang sebesar 28.33 GW atau $28.330 \mathrm{MW}$.

Jepang juga telah menerapkan berbagai kebijakan dan regulasi untuk mempercepat pertumbuhan kapasitas PLT. Sebagai contoh, harga beli energi listrik PLTS yang dua kali lipat dari harga energi yang dibayar pelanggan ke utilitas. Juga, subsidi pada 
investasi awal pembangunan PLTS, dan pinjaman lunak untuk PLTS yang berkapasitas besar. Hal-hal ini telah mendorong peningkatan pemasangan PLTS berkapasitas $10-1.000 \mathrm{~kW}$ secara signifikan.

Pemerintah Amerika Serikat meluncurkan berbagai kebijakan untuk mempercepat perkembangan kapasitas PLTS terpasang. Sebagai contoh program Property-Assessed Clean Energy (PACE) dilaksanakan oleh Pemerintah Daerah melalui pemberian pinjaman $100 \%$ kepada pemilik bangunan untuk membangun PLTS Atap dan membayarnya sebagai bagian dari pembayaran pajak. Juga, adanya program Investment Tax Credits (ITC) yaitu pemberian 30\% investasi PLTS Atap diambil dari pajak yang harus dibayar kepada negara. Kebijakan ini berlaku bagi pelanggan rumah tangga maupun komersial. Sebagai contoh, seperti dilaporkan oleh Solar Energy Industries Association (SEIA) setiap pemilik PLTS Atap mendapat potongan rata-rata sebesar $\$ 5.000$ dari total investasi pemasangan PLTS. Di samping itu, banyak terdapat program insentif seperti Single Family Affordable Solar Housing (SASH) berupa bantuan investasi awal sebesar $\$ 3$ per watt PLTS yang dipasang.

Pemerintah Jerman telah menerapkan berbagai kebijakan untuk mempercepat pertumbuhan PLTS. Kebijakan yang telah dilaksanakan antara lain grosmetering dan juga net-metering. Berbagai tarif telah dikenakan seperti feed-in-tariff sebesar 0.25 Euro cents/kWh hingga 0.45 Euro cents/kWh. Pemerintah Jerman juga memberikan pinjaman untuk investasi PLTS Atap dengan bunga $4.5 \%$ di bawah bunga pasar dengan periode pembayaran selama 10 tahun dan pembayaran dimulai setelah 2 tahun pertama. Juga, pinjaman 100\% untuk PLTS Atap diberikan pada instalasi di bawah $5 \mathrm{kWp}$.

Pemerintah negara bagian di India telah menerapkan berbagai kebijakan untuk mempercepat pertumbuhan kapasitas PLTS. Pemerintah memberikan subsidi pada investasi awal pemasangan PLTS berukuran kecil antar 0.5-1.0 kWp. Setiap pemerintah negara bagian memberikan insentif yang berbeda-beda besarnya namun secara umum semuanya dalam bentuk subsidi investasi awal dan juga skema net-metering dan excess energy serta feed-in-tariff. Pemerintah Pusat India juga memberikan insentif berupa subsidi sebanyak 30\%-70\% investasi awal pembangunan PLTS Atap. Subsidi ini berlaku bagi sektor rumah tangga, sosial, dan juga institusi pendidikan serta kesehatan.

Status terkini tentang kapasitas PLTS terpasang dari negara-negara maju berdasarkan data dari International Renewable Energy Agency (IRENA) 2019 memperlihatkan capaian kapasitas PLTS global yang besar. Hal ini tentu salah satunya adalah akibat stimulasi berbagai kebijakan dan regulasi oleh pemerintah negara-negara tersebut [Gambar 46]. Cina berada di posisi tertinggi dengan total PLTS terpasang terbesar $175.031 \mathrm{MW}$. Dari data 10 negara tersebut, 64\% atau 265.489 MW kapasitas PLTS dunia berada di benua Asia. Indonesia yang menjadi bagian dari Asia dan berada di sekitar garis katulistiwa dengan matahari yang tersedia hampir sepanjang tahun akan dapat menjadi bagian penting dari komunitas PLTS dunia atau paling tidak di wilayah regional ASEAN.

Negara Dengan PLTS Terpasang Terbesar

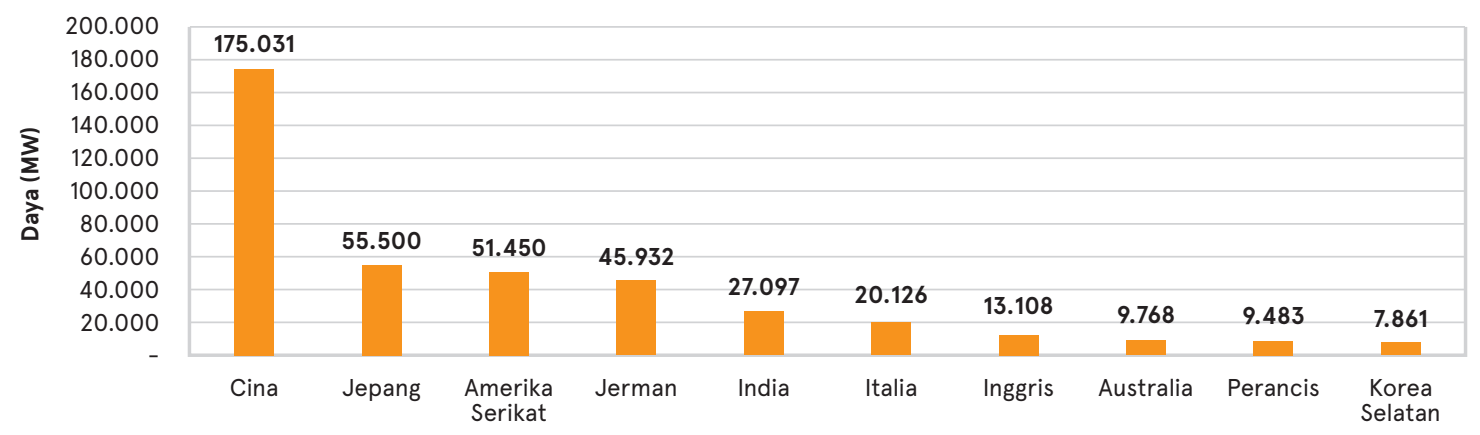

Gambar 46. Negara dengan kapasitas PLTS terbesar di dunia 


\section{Edukasi dan Sosialisasi}

Seperti telah dipaparkan sebelumnya bahwa PLTS Atap sudah mulai berkembang di Bali namun mekanisme dan proses pembangunannya tidak atau belum mengikuti mekanisme dan prinsip dari Permen 49/2018. Sebagian dari PLTS Atap yang sudah beroperasi dibangun sebelum dikeluarkannya Permen tersebut. Agar seluruh komponen masyarakat memahami program PLTS Atap dan aturan terkait maka perlu dilakukan edukasi dan sosialisasi yang komprehensif. Salah satu solusinya adalah membangun pilot proyek PLTS Atap yang dibangun mengikuti mekanisme yang diatur dalam Permen 49/2018 tersebut. Pilot proyek ini dikaji secara komprehensif dan terpadu mulai

\section{Model Pembiayaan}

Pembiayaan PLTS Atap dapat dilakukan dengan mengadopsi berbagai opsi pembiayaan proyekproyek Energi Baru Terbarukan khususnya proyek PLTS yang sudah ada dan mengembangkan model pembiayaan dan pengelolaan yang inovatif.

Pemerintah Pusat melalui Kementerian ESDM telah membangun banyak PLTS di seluruh Indonesia termasuk di Bali. Model kerjasama seperti ini memang tidak lagi akan berkembang di masa depan namun best practice serta lesson learned dari proyek-proyek yang sudah ada bisa dijadikan acuan dalam membangun kerjasama dengan pihak nonpemerintah.

Pemerintah Provinsi Bali yang telah menetapkan program dengan tag-line Bali Hijau Bersih dan Indah dapat memasukkan PLTS Atap sebagai salah satu portofolio program Bali Hijau Bersih dan Indah serta memberikan penghargaan kepada instansi atau masyarakat yang sudah membangun PLTS Atap. Pemerintah Bali bekerjasama dengan Perguruan Tinggi dapat membangun pilot proyek PLTS Atap yang dibangun dengan mengacu pada Permen 49/2018. dari tahap awal pembangunan, pengurusan ijin, hingga beroperasi sehingga betul-betul mengikuti proses dan mekanisme yang telah diatur oleh Permen 49/2018 dan aturan teknis terkait lainnya. Pilot proyek ini perlu dibangun pada lokasi strategis sehingga memberikan dampak maksimal bagi lingkungan di sekitarnya. Pengalaman yang diperoleh selama proses pembangunan dan pengoperasian pilot proyek ini kemudian dikaji dan didokumentasikan secara lengkap lalu didesiminasikan melalui forum diskusi dengan stakeholder, media massa tradisional, website, dan media sosial.

Best practice pilot proyek ini kemudian dapat didiseminasi kepada masyarakat Bali.

PT PLN (Persero) UID Bali sebagai penyedia tenaga listrik dapat mempercepat pertumbuhan kapasitas PLTS Atap dengan model pembiayaan inovatif sehingga meningkatkan peran PLTS dalam bauran pembangkitan tenaga listrik di Bali. Diperlukan eksplorasi model bisnis PLTS oleh PLN sehingga diperoleh model bisnis yang menguntungkan bagi PLN tanpa memberatkan Pelanggan serta disisi lain mendukung pencapaian target PLTS 108 MW tahun 2025. Salah satu model bisnis PLTS adalah penerapan tarif khusus atau tarif hijau (green tariff) yang sudah diiterapkan di Amerika Serikat. Melalui green tariff ini Pelanggan dapat menggunakan $100 \%$ pasokan listriknya dari sumber energi terbarukan yang dibangun PLN. Pelanggan yang ikut dalam program ini mendapatkan Sertifikat Energi Terbarukan.

Banyak BUMN yang beroperasi di Bali seperti Pertamina, Pelindo, Angkasa Pura, dll yang juga memiliki program Corporate Social Responsibility (CSR). Perlu dilakukan eksplorasi dan kerjasama dengan BUMN sehingga program-program CSR dapat diarahkan untuk pembangunan PLTS Atap pada bangunan publik yang ada di Bali. 
Pemerintah Kabupaten/Kota dapat menganggarkan dalam APBD-nya masingmasing sesuai kemampuan alokasi anggaran untuk pembangunan PLTS Atap di wilayah masing-masing atau bekerjasama dengan pihak luar untuk membangun PLTS pada fasilitas milik mereka.

Desa Adat di Bali yang jumlah sangat banyak dan tersebar dapat memasukkan PLTS Atap sebagai salah satu kegiatan pembangunan di lingkungan nya. Pembangunan PLTS Atap ini dapat dimasukkan sebagai salah satu kegiatan yang didanai oleh Dana Desa atau sebagai bagian dari kegiatan ekonomi BUMDes, Lembaga Perkreditan Desa (LPD), dan Koperasi.

Perguruan Tinggi Negeri atau Perguruan Tinggi Swasta di Bali dapat membiayai pembangunan PLTS Atap melalui kegiatan riset yang didukung oleh Kemristekdikti atau kerjasama dengan lembaga lainnya atau pihak swasta.

Industri pariwisata yang terdiri dari hotel, villa, restoran, tempat hiburan atau atraksi, dan fasilitas lainnya dapat membangun PLTS Atap dengan berbagai model pembiayaan sebagai upaya pengurangan pasokan energi dari PLN dan sekaligus sebagai kampanye energi bersih pariwisata atau green tourism yang bisa meningkatkan daya saing dan citra perusahaan. Sektor pariwisata bisa bekerjasama dengan Kontraktor PLTS atau EPC dan juga perusahaan Energy Service Company (ESCO) yang tergabung dalam Asosiasi Perusahaan Pendukung Konservasi Energi Indonesia (APKENINDO) yang memang bergerak dalam bidang jasa pengelolaan energi.

\section{Sumber Daya Manusia}

Pembangunan atau pemasangan PLTS Atap biasanya tidak mengalami kendala karena sudah dikerjakan oleh Badan Usaha yang sudah memiliki kualifikasi. Namun setelah PLTS beroperasi muncul permasalahan teknis terkait pemeliharaan atau perawatan PLTS tersebut. Untuk itu perlu dikembangkan pelatihan atau pendidikan tingkat operator oleh lembaga-lembaga yang kompeten. PTN/PTS/ POLTEK/SMK atau lembaga terkait lainnya perlu bersinergi untuk mengembangkan program pelatihan untuk menghasilkan tenaga-tenaga operator PLTS yang siap untuk mengoperasikan dan memelihara PLTS Atap. Rencana Pemerintah Pusat melalui Kementerian ESDM untuk membangun Politeknik Energi Terbarukan di Bangli adalah salah satu langkah yang tepat untuk menghasilkan teknisi atau operator PLTS yang nantinya bisa membangun ekosistem untuk mendukung PLTS Atap. 


\section{Layanan Purna Jual}

Salah satu kendala yang dihadapi oleh Pelanggan yang sudah memiliki PLTS Atap yang ada di Bali adalah terbatasnya layanan teknis purna jual atau konstruksi. Selama ini Kontraktor PLTS atau EPC biasanya lebih fokus pada pemasangan PLTS dan belum menawarkan jasa pemeliharaan atau perawatan kalau sistem PLTS-nya bukan merupakan pasangan mereka. Khusus bagi pelanggannya sendiri biasanya sudah ditawarkan fasilitas atau kontrak untuk pemeliharaan atau perawatan pasca konstruksi. Ke depan, perlu distimulasi tumbuhnya Badan Usaha skala kecil menengah misalnya UMKM atau instalatir listrik berkompetensi PLTS yang bergerak dibidang jasa pemeliharaan atau perawatan sehingga terbentuk ekosistem yang lengkap untuk menjaga keberlanjutan PLTS Atap.

\section{Koneksi Ke Jaringan PLN}

Salah satu tahapan penting agar PLTS Atap dapat beroperasi dan bisa mengurangi pasokan energi dari PLN adalah sambungan dengan jaringan PLN melalui kWh meter ekspor-impor. Berdasarkan Permen 49/2018, peran dan tanggung jawab PLN sudah cukup jelas dimana PLN akan menyediakan dan memasang kWh meter di lokasi PLTS Atap apabila pelanggan dan PLTS Atap yang dibangun sudah memenuhi seluruh persyaratan teknis dan administrasi yang telah ditentukan. PLN sendiri sudah menyiapkan langkah-langkah permohonan penyambungan PLTS Atap ke jaringan PLN. Panduan ini sudah dilengkapi dengan perkiraan waktu dalam satuan hari kapan sebuah PLTS Atap bisa disambungkan ke jaringan PLN. Panduan ini perlu dilengkapi dengan persyaratan teknis yang detail dan lengkap sehingga dapat dijadikan acuan oleh Pelanggan atau Kontraktor PLTS. Namun, dari diskusi dengan Kontraktor PLTS atau Badan Usaha, bahwa waktu permohonan pemasangan kWh meter eksim perlu diperpendek sehingga Pelanggan yang sudah siap membangun PLTS Atap mendapat dukungan yang kuat atas partisipasinya membangun PLTS. Percepatan penyambungan PLTS Atap ke jaringan PLN ini juga akan berdampak terhadap waktu pencapaian target kapasitas PLTS yang telah ditetapkan. 


\section{Daftar Pustaka}

Arimbawa P A R, Kumara I N S, Hartati R S. 2016. Studi Pemanfaatan Catu Daya Hibrida PLTS 3,7 kWp dan PLN pada Instalasi Pengolahan Air Limbah Desa Pemecutan Kaja Denpasar Bali. Teknologi Elektro, Vol. 15 No. 2 Juli - Desember 2016. Hal. $33-38$

Badan Pusat Statistik Kabupaten Badung, 2018. Kabupaten Badung dalam Angka 2018. Badung: Badan Pusat Statistik.

Badan Pusat Statistik Kabupaten Bangli, 2018. Kabupaten Bangli dalam Angka 2018. Bangli: Badan Pusat Statistik.

Badan Pusat Statistik Kabupaten Buleleng, 2018. Kabupaten Buleleng dalam Angka 2018. Buleleng: Badan Pusat Statistik.

Badan Pusat Statistik Kabupaten Gianyar, 2018. Kabupaten Gianyar dalam Angka 2018. Gianyar: Badan Pusat Statistik.

Badan Pusat Statistik Kabupaten Jembrana, 2018. Kabupaten Jembrana dalam Angka 2018. Jembrana: Badan Pusat Statistik.

Badan Pusat Statistik Kabupaten Karangasem, 2018. Kabupaten Karangasem dalam Angka 2018. Karangasem: Badan Pusat Statistik.

Badan Pusat Statistik Kabupaten Klungkung, 2018. Kabupaten Klungkung dalam Angka 2018. Klungkung: Badan Pusat Statistik.

Badan Pusat Statistik Kabupaten Tabanan, 2018. Kabupaten Tabanan dalam Angka 2018. Tabanan: Badan Pusat Statistik.

Badan Pusat Statistik Kota Denpasar, 2018. Kota Denpasar dalam Angka 2018. Denpasar: Badan Pusat Statistik.

Badan Pusat Statistik ProvinsiPropinsi Bali, 2017. Wilayah Kerja Statistik ProvinsiPropinsi Bali 2017. Bali : Badan Pusat Statistik.

Badan Pusat Statistik ProvinsiPropinsi Bali, 2018. Bali Dalam Angka 2018. Bali: Badan Pusat Statistik.

Folsom Labs. 2014. HelioScope User Manual

Goel, M., 2016. Solar rooftop in India: Policies, challenges and outlook. Green Energy \& Environment, 1(2), pp.129-137. 
Gunawan N S, Kumara I N S, Irawati R. 2019. Unjuk Kerja pembangkit Listrik Tenaga Surya (PLTS) 26,4 kWp pada Sistem Smart Microgrid UNUD. E-Journal Spektrum Vol. 6. No. 3, September 2019.

I. A. D. Giriantari and R. Irawati, "Smart microgrid system with hybrid system supply: Udayana university pilot project design," 2016 International Conference on Smart Green Technology in Electrical and Information Systems (ICSGTEIS), Bali, 2016, pp. 178-181. doi: 10.1109/ICSGTEIS.2016.7885785

I. N. S. Kumara, W. G. Ariastina, I. W. Sukerayasa and I. A. D. Giriantari, "1 MWp grid connected PV systems in the village of Kayubihi Bali; Review on location's characteristics and its technical specifications," 2013 International Conference on Information Technology and Electrical Engineering (ICITEE), Yogyakarta, 2013, pp. 306-311. doi: 10.1109/ICITEED.2013.6676258

I.N.S. Kumara, W. G. Ariastina, I. W. Sukerayasa and I. A. D. Giriantari, "On the potential and progress of renewable electricity generation in Bali," 2014 6th International Conference on Information Technology and Electrical Engineering (ICITEE), Yogyakarta, 2014, pp. 1-6. doi: 10.1109/ICITEED.2014.7007944

International Energy Agency (IEA), 100000 Roofs Solar Power Programme Germany, https://www.iea.org/policiesandmeasures/pams/germany/name21000-en.php

International Renewable Energy Agency (IRENA), Capacity and Generation Country Rankings (Solar), http://resourceirena.irena.org/gateway/dashboard

Kepmen ESDM 1567/2018, Rencana Usaha Penyediaan Tenaga Listrik (RUPTL) PT Perusahaan Listrik Negara (Persero) 2018 sd 2027

Kumara I N S, Urmee T, Divayana Y, Setiawan I N, Pawitra A A G A, Jaya A. 2018. Implementation of Grid-connected PV Plant in Remote Location in Sumbawa island of Indonesia:Lesson Learned. ICSGTEIS 25-27 Oktober 2018. Hal. 203209.

Kumara K V, Kumara I N S, Ariastina W G. 2018. Tinjauan Terhadap PLTS 24 kW Atap Gedung PT. Indonesia Power Pesanggaran Bali. E- Journal Spektrum Vo. 5, No. 2 Desember 2018. Hal. 26 - 35

Menteri Energi Dan Sumber Daya Mineral. 2018. Peraturan Menteri Energy dan Sumber Daya Mineral Republik Indonesia Nomor 38 Tahun 2018 Tentang Tata Cara Akreditasi Dan Sertifikasi Ketenagalistrikan. 
Menteri Energi Dan Sumber Daya Mineral. 2018. Peraturan Menteri Energi dan Sumber Daya Mineral Republik Indonesia Nomor 49 Tahun 2018 Tentang Penggunaan Sistem Pembangkit Listrik Tenaga Surya Atap Oleh Konsumen PT. Perusahaan Listrik Negara (Persero).

Office of Energy Efficiency \& Renewable Energy, Property Assessed Clean Energy Programs, https://www.energy.gov/eere/slsc/property-assessedclean-energy-programs

Peraturan Daerah ProvinsiPropinsi Bali No 4/2019 tentang Desa Adat Di Bali

Presiden Republik Indonesia. 2011. Peraturan Pemerintah Republik Indonesia Nomor 50 Tahun 2011 Tentang Rencana Induk Pembangunan Kepariwisataan Nasional Tahun 2010 - 2025.

Presiden Republik Indonesia. 2017. Peraturan Presiden Republik Indonesia Nomor 22 Tahun 2017 Tentang Rencana Umum Energi Nasional (RUEN).

RETScreen International. 2005. RETScreen Software Online User Manual Photovoltaic Project Model.

Saskara I P E, Kumara I N S, Sukerayasa I W. 2018. Comparison of PV Rooftop Energy Production at Denpasar City Office Building. ICSGTEIS 25-27 Oktober 2018 Hal. 150 - 156

Setiawan I K A, Kumara I N S, Sukerayasa, I W. 2014. Analisis Unjuk Kerja Pembangkit Listrik Tenaga Surya (PLTS) Satu MWp Terinterkoneksi Jaringan di Kayubihi, Bangli. Teknologi Elektro, Vol. 13 No. 1 Januari - Juni 2014. Hal. 27 - 33

US Department of Energy, Database of State Incentives for Renewables \& Efficiency, https://www.dsireusa.org/

Wicaksana M R, Kumara I N S, Giriantari I A D, Irawati R. 2019. Unjuk Kerja Pembangkit Listrik Tenaga Surya Rooftop 158 kWp pada Kantor Gubernur Bali. E-Journal Spektrum Vol. 6. No. 3, September 2019.

World Resources Institue (WRI), Green Tariffs Take Off in the US, Expand Access to Renewable Energy, https://www.wri.org/blog/2016/10/green-tariffs-takeus-expand-access-renewable-energy 

CORE CENTER FOR COMMUNITY BASED
RENEMABIE ENERGY UDAYANA UNIVERSITY - BALI
GREGWrFACE 